Aus der Abteilung Kardiologie und Pneumologie

(Prof. Dr. med. G. Hasenfuß)

im Zentrum Innere Medizin

der Medizinischen Fakultät der Universität Göttingen

\title{
Untersuchung einer Calcineurin-bindungsdefizienten FKBP12.6-Mutante in Kardiomyozyten
}

\author{
INAUGURAL - DISSERTATION \\ zur Erlangung des Doktorgrades \\ der Medizinischen Fakultät der \\ Georg-August-Universität zu Göttingen
}

vorgelegt von

Astrid Kania

aus

Staßfurt

Göttingen 2010 
Dekan:

I. Berichterstatter:

II. Berichterstatter/in:

III. Berichterstatter/in:
Prof. Dr. med. C. Frömmel

Prof. Dr. med. G. Hasenfuß

Prof. Dr. med. J. Wienands

Prof. Dr. med. Dr. rer. nat. T. Crozier

Tag der mündlichen Prüfung: 11.08.2010 


\section{INHALTSVERZEICHNIS}

SEITE

1. EINLEITUNG 5

1.1. Aufbau und assoziierte Proteine des kardiozytären Membransystems 5

1.1.1. Transversalsystem

1.1.2. Longitudinalsystem 5

1.2. Physiologie der Herzmuskelkontraktion

1.3. Kalziumfreisetzungskanäle und assoziierte Proteine

1.3.1. RyR und IP3R

1.3.2. RyR und FKBP

1.3.3. RyR und FKBP12.6

1.3.4. RyR und Calcineurin

1.4. Herzinsuffizienz

1.4.1. Definition und Ätiologie

$\begin{array}{ll}\text { 1.4.2. Kompensationsmechanismen___ } & 14\end{array}$

1.4.3. Dekompensation

1.5. Vorarbeiten: Viruskonstrukt

1.6. Fragestellung

2. MATERIAL Und METHODEN

2.1. DNA-Mutation

19

2.2. Herstellung rekombinanter Proteine

2.2.1. Klonierung und Kultur

2.2.2. Expressionskultur

2.2.3. Affinitätsaufreinigung

2.2.4. SDS-Polyacrylamid-Gelelektrophorese (SDS-PAGE)

2.2.5. Proteinbestimmung

2.3. Calcineurinaffinitäts-Assay___ 23

2.4. Rotamase-Assay___ 24

2.5. Myozytenisolation_ 25

2.6. Transfektion__ 26

2.6.1. Zellkulturen zur RNA- und Proteingewinnung___ 26

2.6.2. Zellkulturen für B-Galaktosidase-Assay___ 27

2.6.3. Zellkulturen zur Kontraktionsmessung__ 27

2.7. B-Galaktosidase-Assay____ 27

2.8. Reverse-Transkriptase - Polymerase-Kettenreaktion (RT-PCR)___ 28

2.8.1. RNA-Isolation

2.8.2. Synthese komplementärer DNA (cDNA)__ 29

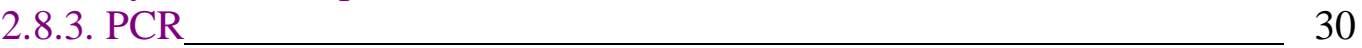

2.8.4. Gelelektrophorese___ 31

2.9. SDS-PAGE und Western Immunoblot___ 31

2.9.1. Lysatherstellung und Proteinkonzentrationsbestimmung__ 31

2.9.2. SDS-PAGE

$\begin{array}{ll}\text { 2.9.3. Transfer auf Nitrozellulose__ } & 32\end{array}$

$\begin{array}{ll}2.9 .4 . \text { Immundetektion___ } & 32\end{array}$ 
2.10. Myozytenkontraktionsmessung__ 32

2.10.1. Versuchsaufbau und Messbedingungen__ 32

2.10.2. Statistika__ 34

2.11. Verwendete Lösungen und Substanzen___ 34

2.11.1. Herstellung rekombinanter Proteine__ 34

2.11.2. Calcineurinaffinitäts-Assay___ 35

2.11.3. Rotamase-Assay__ 35

2.11.4. Myozytenisolation_ 35

2.11.5. Transfektion__ 36

2.11.6. ß-Galaktosidase-Assay___ 36

2.11.7. Reverse-Transkriptase - Polymerase-Kettenreaktion (RT-PCR)__ 36

2.11.8. SDS-PAGE und Western Immunoblot___ 37

2.11.9. Myozytenkontraktionsmessungen__ 37

3. ERGEBNISSE__ 38

3.1. DNA-Mutation zur Erzeugung einer Calcineurin-Bindungsdefizienz___ 38

3.2. Rekombinante Herstellung von FKBP und Charakterisierung ___ 39

3.2.1. Proteinexpression__ 39

3.2.2. Calcineurinaffinitäts-Assay zur Untersuchung der Interaktion von

FKBP mit FK506 und Calcineurin___ 41

3.2.3. Rotamase-Assay zum Nachweis erhaltener FK506-Affinität von

FKBP12.6 $6^{\mathrm{G} 89 \mathrm{PV} 90 \mathrm{~K}} \quad 42$

3.3. Kontrolle der Transfektionseffizienz rekombinanter Adenoviren in

Kardiomyozyten

3.3.1. Bestimmung der für eine hohe Transfektionsrate benötigten

Virusmenge durch den B-Galaktosidase-Assay___ 43

3.3.2. RT-PCR zum Nachweis spezifischer mRNA-Transkription in adenoviral transfizierten Kardiomyozyten

3.3.3. Western Immunoblot zum Nachweis der Expressionssteigerung von

FKBP nach adenoviralem Gentranfer

3.4. Messung der relativen Zellverkürzung adenoviral transfizierter

Kardiomyozyten 38

4.1. Die Interaktion zwischen RyR2 und FKBP12.6

4.2. Eigenschaften von FKBP12.6 G89PV90K 48

4.3. Kontrolle der Genübertragung in adulte Kaninchenmyozyten___ 50

4.4. Myozytenkontraktionsmessungen__ 51

4.5. Bewertung der Ergebnisse___ 52

5. ZUSAMMENFASSUNG__ 55

6. LITERATURVERZEICHNIS___ 57 


\section{EINLEITUNG}

\subsection{Aufbau und assoziierte Proteine des kardiomyozytären Membransystems}

\subsubsection{Transversalsystem}

Die Zellmembran der Kardiomyozyten (Sarkolemm) besitzt in regelmäßigen Abständen Einstülpungen, die senkrecht zu den Muskelfibrillen verlaufen und deshalb als transversale Tubuli (T-Tubuli) bezeichnet werden. Durch ihre direkte Nachbarschaft zum sarkoplasmatischen Retikulum (SR), dem unter anderem eine Rolle als Kalziumspeicher der Zelle zukommt, wird die rasche Umsetzung einer elektrischen Erregung in Kalziumfreisetzung und Zellkontraktion (elektromechanische Kopplung) gewährleistet. Entlang der T-Tubuli sind die Dihydropyridinrezeptoren (DHPR) lokalisiert (Sun et al. 1995). Der DHPR vermittelt in der Herzmuskelzelle bei Depolarisation des Sarkolemms über einen ins Zellinnere gerichteten Kalziumstrom die Öffnung des sogenannten Ryanodinrezeptors (RyR), dem Kalziumfreisetzungskanal des SR (Cannell et al. 1995).

Ebenfalls im Sarkolemm sind die $\mathrm{Na}^{+} / \mathrm{Ca}^{2+}$-Austauscher (NCX) lokalisiert. Ein NCX transportiert ein Kalziumion in den Extrazellularraum im Austausch gegen drei Natriumionen, die entlang des elektrischen Gradienten und ihres Konzentrationsgefälles nach intrazellulär verschoben werden (Bridge et al. 1990). Das Konzentrationsgefälle für $\mathrm{Na}^{+}$wird dabei von der $\mathrm{Na}^{+} / \mathrm{K}^{+}$-ATPase aufrechterhalten. Der oben beschriebene „forward mode“ wird aufgrund der geringen Kalzium-Affinität des NCX erst bei hohen Kalzium-Konzentrationen innerhalb der Zelle aktiviert und kann abhängig von den intra- und extrazellulären $\mathrm{Na}^{+}-$und $\mathrm{Ca}^{2+}$ Konzentrationen sowie dem Membranpotential auch in umgekehrter Richtung (,reverse mode") erfolgen (Kohomoto et al. 1994, Weber et al. 2003).

Die $\mathrm{Na}^{+} / \mathrm{Ca}^{2+}$-Austauscher reduzieren in der Diastole das systolisch ins Zytoplasma freigesetzte Kalzium speziesabhängig bis zu $28 \%$ (mit Ausnahme von Ratte und Maus) und stellen so den wichtigsten sarkolemmalen Eliminationsweg für $\mathrm{Ca}^{2+}$ dar (Bers 2000, Shigekawa und Iwamoto 2001).

Im Sarkolemm sind ferner $\mathrm{Ca}^{2+}$-ATPasen vorhanden, die unter Spaltung von ATP Kalziumionen in den Extrazellularraum transportieren, aber in elektrisch erregbaren Zellen nur in geringem Maße zur Kalziumelimination beitragen (Hammes et al. 1998). 


\subsubsection{Longitudinalsystem}

Das endoplasmatische Retikulum der Herzmuskelzelle (SR) bildet längliche, membranöse Strukturen. Basierend auf ihrer parallelen Ausrichtung zu den Mukelfibrillen, werden sie logitudinale Tubuli (L-Tubuli) genannt. Hauptsächlich in ihren erweiterten Endigungen, den Terminalzisternen, werden an Calsequestrin gebundene Kalziumionen gespeichert (Mitchell et al. 1988). Da dieser Bereich des SR in engem Kontakt zum Sarkolemm steht, wird er auch als junktionales SR bezeichnet. In der Membran befinden sich die nach ihrer Affinität zu dem Pflanzenalkaloid Ryanodin benannten Ryanodinrezeptoren (RyR), die als wichtigste Kalziumfreisetzungskanäle des SR der Herzmuskelzelle eine entscheidende Rolle bei der elektromechanischen Kopplung spielen (Marks 1997). Calsequestrin, das Kalziumionen mit mäßiger Affinität aber hoher Kapazität bindet, wird über die transmembranen Proteine Junctin und Triadin an den RyR verankert (Zhang L et al. 1997). Es wird vermutet, dass dieser Komplex bei der Regulation der Kalziumfreisetzung aus dem SR ebenfalls eine wichtige Rolle spielt (Groh et al. 1999). Die genauen Mechanismen sind aber bis zum jetzigen Zeitpunkt nicht bekannt.

Außerhalb des junktionalen SR befindet sich in den L-Tubuli die SR-Ca ${ }^{2+}$-ATPase (SERCA), die am Ende der Zellkontraktion $\mathrm{Ca}^{2+}$-Ionen aus dem Zytoplasma zurück ins SR pumpt. Da die SERCA für den Transport von zwei Kalziumionen ein Molekül ATP hydrolysiert und dabei mehrere Konformationsänderungen durchläuft, gehört sie zur Familie der p-TypATPasen (MacLennan et al. 1997). Sie ist zu etwa $70 \%$ an der zytosolischen $\mathrm{Ca}^{2+}$-Elimination in der Diastole beteiligt. Ihre Aktivität ist Voraussetzung zur regulären Wiederherstellung der diastolischen Kalziumkonzentration und damit der Relaxation der Zelle (Bers 2000).

Die Transportaktivität der SR-Ca ${ }^{2+}$-ATPase wird durch Phospholamban reguliert. Im unphosphorylierten Zustand inhibiert es die SERCA durch Bindung an deren zytosolischen Seite. Nach Phosphorylierung durch cAMP- oder $\mathrm{Ca}^{2+} / \mathrm{Calmodulin-abhängige} \mathrm{Proteinkinasen}$ erfolgt eine Konformationsänderung des Phospholambans, die die Ablösung von der SERCA und so die Aufhebung der Inhibition nach sich zieht (James et al. 1989).

\subsection{Physiologie der Herzmuskelkontraktion}

Der Kontraktionszyklus einer Herzmuskelfaser beginnt mit der Überleitung der elektrischen Erregung von einer benachbarten Zelle. Ein überschwelliger Reiz aktiviert zunächst spannungssensitive $\mathrm{Na}^{+}$-Kanäle, die durch einen $\mathrm{Na}^{+}$-Einwärtsstrom eine Depolarisation des Sarkolemms bzw. die Ausbildung eines Aktionspotentials ermöglichen und bereits nach 
wenigen Millisekunden wieder inaktiviert werden. Die Depolarisation breitet sich so über das Sarkolemm in die T-Tubuli aus und aktiviert dort lokalisierte DHPR, die einen langsamen ins Zellinnere gerichteten $\mathrm{Ca}^{2+}$-Strom erzeugen. Basierend auf seiner im Vergleich zum $\mathrm{Na}^{+}-$ Kanal langsamen Inaktivierung wird er auch als long-lasting- oder L-Typ-Ca ${ }^{2+}$-Kanal bezeichnet.

Im Gegensatz zum Skelettmuskel, wo die DHPR als Ladungssensor fungieren und durch depolarisationsinduzierte Konformationsänderungen direkt die RyR des SR aktivieren, wird in der Herzmuskelzelle durch den $\mathrm{Ca}^{2+}$-Einstrom über die DHPR die Öffnung direkt benachbarter RyR und damit die $\mathrm{Ca}^{2+}$-Freisetzung aus dem SR getriggert. Dieser Mechanismus ist für die Herzmuskelzelle spezifisch (Näbauer et al. 1989) und wird als „Kalzium-induzierte Kalziumfreisetzung“ (CICR) bezeichnet (Fabiato A 1983). Der RyR zeigt eine glockenförmige Aktivitätsabhängigkeit von der zytosolischen $\mathrm{Ca}^{2+}$-Konzentration (Bezprozvanny et al. 1991). In $\mathrm{Ca}^{2+}$ - Konzentrationsbereichen von $\mathrm{nmol} / \mathrm{l} \mathrm{bis} \mu \mathrm{mol} / \mathrm{l}$ wird der Kanal aktiviert, die Inaktivierung erfolgt bei Werten im mmol/l-Bereich (Marks 2000), aber auch spannungsabhängig (Sitsapesan et al. 1995) und bei abnehmender $\mathrm{Ca}^{2+}$-Konzentration im SR (Xu und Meissner 1998). Des Weiteren ist der Einfluss modulatorischer Proteine bei der Regulation des RyR Gegenstand vieler Untersuchungen (siehe 1.3.).

Erst durch die Öffnung des RyR gelangen genügend Kalziumionen ins Zytosol, um die Kontraktion der Myofilamente auszulösen. Dabei wird Troponin $\mathrm{C}$ durch Bindung von $\mathrm{Ca}^{2+}$ aktiviert und der Troponinkomplex verschiebt Tropomyosin, das in Ruhe die MyosinBindungsstelle am Aktin blockiert (Solaro und Rarick 1998). So können die Myosinköpfchen in $90^{\circ}$-Stellung an Aktin ansetzen und es unter ATP-Spaltung und einer Beugung von $45^{\circ}$ in Richtung des Myosins ziehen, so dass sich die Filamentbereiche ineinander verschieben, sich jedoch nicht selbst verkürzen. Dieser Vorgang wird als Filamentgleiten bezeichnet (Huxley und Hanson 1954) und stellt die Grundlage der Kontraktion der Zelle dar. Unter Spaltung eines weiteren Moleküls ATP wird die Myosin-Aktin-Bindung wieder gelöst und der Querbrückenzyklus kann erneut erfolgen.

Für die Repolarisation des Sarkolemms ist das Zusammenspiel mehrerer speziell an die Herzmuskelzelle angepasster $\mathrm{K}^{+}$-Kanalsysteme verantwortlich. Vereinfacht dargestellt wird ein Teil der $\mathrm{K}^{+}$-Kanäle erst stark verzögert zur Depolarisation aktiviert und erzeugt einen auswärts gerichteten Kaliumionenstrom, der Re- und Hyperpolarisation einleitet. Durch die Negativierung des Membranpotentials sowie $\mathrm{K}^{+}$-konzentrationsabhängig werden weitere $\mathrm{K}^{+}$Kanäle geöffnet, die als Einwärts-Gleichrichter bezeichnet werden und hauptverantwortlich für die Ausbildung des Ruhemembranpotentials sind. Das Ruhemembranpotential wird von 
der $\mathrm{Na}^{+} / \mathrm{K}^{+}$-ATPase aufrecht erhalten. Nur durch die verzögerte Aktivierung des $\mathrm{K}^{+}$Kanalsystems und die verlangsamte Inaktivierung der L-Typ-Ca ${ }^{2+}$-Kanäle ist die Ausbildung der Herzmuskel-typischen Plateauphase des Aktionspotentials möglich (Fabiato A und Fabiato F 1979).

Voraussetzung für die Relaxation der Myofibrillen ist aber die Wiederherstellung der diastolischen $\mathrm{Ca}^{2+}$-Konzentration. Das ins Zytosol freigesetzte $\mathrm{Ca}^{2+}$ wird über die SERCA ins SR zurückgepumpt und steht so beim nächsten Kontraktionszyklus wieder zur Verfügung. NCX, sarkolemmale $\mathrm{Ca}^{2+}$-ATPase und die $\mathrm{Ca}^{2+}$-Aufnahme über Mitochondrien sorgen für die restliche $\mathrm{Ca}^{2+}$-Elimination (siehe oben).

\subsection{Kalziumfreisetzungskanäle und assoziierte Proteine}

\subsubsection{RyR und IP3R}

Die Freisetzung von $\mathrm{Ca}^{2+}$ aus dem zellulären Speicher (endo- bzw. sarkoplasmatischen Retikulum) in das Zytosol wird durch zwei Gruppen hochkonservierter, strukturell verwandter $\mathrm{Ca}^{2+}$-Freisetzungskanäle gesteuert, die nach ihrer Affinität zu bestimmten Liganden als Ryanodinrezeptoren (RyR) und Inositol-1,4,5-trisphosphat-Rezeptoren (IP3R) bezeichnet werden und sich durch Größe, pharmakologisches Profil und Funktion unterscheiden.

Beide Kanäle bestehen aus 4 identischen Untereinheiten, die jeweils ein Molekulargewicht von $565 \mathrm{kDa}(\mathrm{RyR})$ bzw. etwa $300 \mathrm{kDa}$ (IP3R) besitzen und zusammen das eigentliche Kanalprotein formen. Der carboxy-terminale, hydrophobe Abschnitt einer Untereinheit bildet die transmembranäre Verankerung des Proteins, das amino-terminale, hydrophile Ende reicht ins Zytoplasma und formt ein Molekülgerüst, das eine Vielzahl von Bindungsstellen für regulatorische Proteine besitzt.

Von der Gruppe der IP3R sind bis zum jetzigen Zeitpunkt fünf Isoformen bekannt, die in nahezu allen Geweben exprimiert werden (Ferris und Snyder 1992). Die lange Aktivierungskaskade der IP3R über G-Proteinrezeptor- oder Thyrosinkinase-gekoppelte Aktivierung der Phospholipase $\mathrm{C}$ und Generierung von IP3 sowie die 50fach geringere Expression in der Herzmuskelzelle lassen es unwahrscheinlich erscheinen, dass sie an der elektromechanischen Kopplung der quergestreiften Muskelzelle beteiligt sind (Moschella und Marks 1993). Vielmehr wird vermutet, dass sie spezielle Regulationsfunktionen z.B. der Kontraktion glatter Muskelzellen (Berridge 1993), der Rhythmusgenerierung im Herzen (Gorza et al. 1993) sowie des Zellwachstums und der Apoptose (Marks 1997) übernehmen. 
Der RyR stellt als Homotetramer mit einem Molekulargewicht von etwa $2300 \mathrm{kDa}$ den größten bis zum jetzigen Zeitpunkt bekannten Ionenkanal dar (Marks 2001). Es sind drei Isoformen bekannt, die vorwiegend in quergestreifter Skelettmuskulatur (RyR1), in Herzmuskelzellen und Gehirn (RyR2) sowie in Hippocampus und Dienzephalon (RyR3) exprimiert werden, wobei in den meisten Geweben mehrere RyR-Isoformen gleichzeitig vorkommen. Sie weisen untereinander Aminosäuresequenzhomologien bis zu $66 \%$ auf (Marks 1997).

Während die genaue Funktion des RyR3 nicht genau geklärt ist, ist die Hauptaufgabe des RyR1 und RyR2 die schnelle Freisetzung von $\mathrm{Ca}^{2+}$ aus dem SR während des Aktionspotentials, was zur Kontraktion quergestreifter Muskulatur notwendig ist.

Die RyR sind in Gruppen angeordnet, so dass jeder Kanal vier benachbarte Kanäle kontaktiert (Franzini-Armstrong et al. 1999). Der zytoplasmatische Anteil des Kanals, mehr als 90\% des Gesamtproteins, wird als „foot-structure“ bezeichnet und überspannt das Zytosol bis zur Zellmembran (Franzini-Armstrong 1970). Er vermittelt die Öffnung des RyR (siehe 1.2.) und ist Angriffsort einer Vielzahl regulatorischer Proteine. So binden die Proteinkinase A (PKA), die $\mathrm{Ca}^{2+} /$ Calmodulin- abhängige Kinase II (CaMKII) sowie die Proteinphosphatasen 1 und 2A (PP1, PP2A) an die Untereinheiten des RyR und beeinflussen dessen Aktivitätsgrad. PKA, die über ein Ankerprotein (mAKAP) an eine Untereinheit bindet (Ruehr et al. 2003), erhöht durch Phosphorylierung der Aminosäure $\operatorname{Ser}^{2809}$ (Marx et al. 2000) und konsekutiver Abdissoziation eines Regulatorproteins (siehe 1.3.3.) die Offenwahrscheinlichkeit des Kanals (Valdivia et al. 1995). Ähnlich führt die Phosphorylierung der Aminosäure $\operatorname{Ser}^{2815}$ durch die CaMKII zu einer erhöhten $\mathrm{Ca}^{2+}$-Freisetzung über den Kanal (Wehrens et al. 2004), was als Beitrag zur Frequenzinotropie gedeutet wird (Maier und Bers 2002). Des Weiteren bewirkt die Oxidation von Sulfhydrylgruppen/Disulfidbrücken des RyR durch Stickstoffmonoxid (NO) eine RyRAktivierung, die durch Reduktion wieder aufgehoben werden kann (Xu et al. 1998, Barouch et al. 2002).

Ferner reguliert das $22 \mathrm{kDa}$ schwere Protein Sorcin den Aktivitätszustand des RyR. Das hauptsächlich in der Nähe der T-Tubuli lokalisierte Protein (Meyers et al. 2003) durchläuft abhängig von der zytoplasmatischen $\mathrm{Ca}^{2+}$-Konzentration Konformationsänderungen, die es von der zytoplasmatisch gelösten zur membrangebundenen Form überführen (Mella et al. 2003). So koppelt Sorcin bei hohen $\mathrm{Ca}^{2+}$-Konzentration unter anderem an den RyR (Meyers et al. 1995) und verringert dessen Offenwahrscheinlichkeit sowohl im Ruhe- als auch im Aktivitätszustand (Seidler et al. 2003, Farrell et al. 2003). Dementsprechend wird ihm eine Rolle an der Termination des CICR zugeschrieben. 
Die genaue Anzahl, die Funktionen sowie Interaktionen der Regulatorproteine untereinander sind gegenwärtig noch nicht vollständig verstanden und stellen den Gegenstand intensiver Forschungsarbeit dar.

\subsubsection{RyR und FKBP}

Die Gruppe der FK506-bindenden Proteine (FKBP) wurde nach ihrer Funktion als zytoplasmatische Rezeptoren für die Immunsuppressiva FK506 (Tacrolimus) und Rapamycin (Sirolimus) benannt (Siekierka et al. 1989). Der Komplex aus FKBP und FK506 bindet und inhibiert die Proteinphosphatase Calcineurin, FKBP in Verbindung mit Rapamycin die Rapamycin-FKBP-Targets 1 und 2 (RAFT1 und 2), wodurch die zelluläre Immunantwort unterdrückt wird (Sabatini et al. 1994).

Die natürliche Funktion dieser Proteingruppe war lange Zeit ungeklärt. Bei der Sequenzierung des RyR wurde ein eng mit dem Kanal assoziiertes Protein isoliert (Marks et al. 1989 und 1990), das erst später als FKBP12 identifiziert werden konnte (Collins 1991). Zur Gruppe der FKBP gehören verschieden Isoformen unterschiedlicher Größe und Funktion, die zwischen den Spezies hochkonserviert sind und ubiquitär exprimiert werden. Gemeinsam ist den FKBP eine Peptidyl-prolyl-cis-trans-Isomeraseaktivität, auch als Rotamaseaktivität bezeichnet (Fischer et al. 1989), die durch die Bindung der Immunsuppressiva unterdrückt wird (Harding et al. 1989). Ob die Rotamaseaktivität der FKBP im Zusammenhang mit der RyR-Regulation steht, ist nicht geklärt. Bekannt ist aber, dass Immunsuppressiva wie Rapamycin FKBPMoleküle vom RyR lösen und so die natürliche Funktion der FKBP am RyR unterbinden können (Kaftan et al. 1996).

Von Bedeutung für die Funktion quergestreifter Muskulatur sind FKBP12.0 und 12.6, die sich in nur 18 von 108 AS unterscheiden. Es wurde gezeigt, dass FKBP12.0 (und FKBP12.6 in vitro) mit dem skelletalen RyR1 assoziiert sind und FKBP12.6 spezifisch an den kardialen RyR2 bindet (Timerman et al. 1996). In späteren Untersuchungen zeigten FKBP12.0Knockout-Mäuse aber ähnlich schwere kardiale Störungen (DCM, Ventrikelseptumdefekte) wie FKBP12.6-defiziente Mäuse (Hypertrophie), was eine Verbindung von FKBP12.0 mit dem RyR2 vermuten ließ (Shou et al. 1998). Dies wurde durch einen Speziesvergleich untermauert, der zeigte, dass bei 7 von 8 Spezies beide FKBP Isoformen mit dem RyR2 assoziiert sind (Jeyakumar et al. 2001). Welche Isoform bei der Regulation des RyR2 vorherrscht, wird bis heute unterschiedlich diskutiert. Eine neuere Arbeit zeigt jedoch, dass auch FKBP12.0 in zahlreichen Spezies an den RyR2 bindet und diesen in seiner $\mathrm{Ca}^{2+}$ Freisetzungsfunktion beeinflussen kann (Seidler et al. 2007). 


\subsubsection{RyR und FKBP12.6}

FKBP12.6 ist in der Herzmuskelzelle neben FKBP12.0 das wichtigste RyR-assoziierte Protein aus der Gruppe der FK506-bindenden Proteine. Von vielen Arbeitsgruppen wird postuliert, dass FKBP12.6 allein spezifisch an den RyR2 binden kann. Dafür werden die drei Aminosäuren Gln ${ }^{31}, \mathrm{Asn}^{32}$ und Phe ${ }^{59}$ in der Sequenz des FKBP12.6 verantwortlich gemacht (Xin et al 1999).

FKBP12.6 bindet mit einer Stoichiometrie von einem Molekül pro RyR-Untereinheit an den Kanal (Jayaraman et al. 1992) und steht mit den im Zytosol gelösten Molekülen in Austausch (Timerman et al. 1995). Durch FKBP wird der Kanal stabilisiert und zeigt eine verringerte Offenwahrscheinlichkeit und damit einen verminderten $\mathrm{Ca}^{2+}$-Verlust in der Diastole. Außerdem werden benachbarte RyR durch FKBP funktionell verbunden und bilden eine $\mathrm{Ca}^{2+}$ Freisetzungseinheit, die durch koordinierte Öffnung und Schließung $\mathrm{Ca}^{2+}$ effektiver freisetzt, was als „coupled gating“ bezeichnet wird (Brillantes et al. 1994, Marx et al. 2001, Lehnart et al. 2003). Prestle et al. (2001) konnten diesen Effekt durch adenovirale Transfektion und Überexpression in isolierten Kardiomyozyten ebenfalls zeigen. Durch die Stabilisierung der RyR sank der diastolische $\mathrm{Ca}^{2+}-$ Verlust und der SR- $\mathrm{Ca}^{2+}-$ Gehalt wurde erhöht. Die so gesteigerte $\mathrm{Ca}^{2+}$-Freisetzung in der Systole bedingte eine verbesserte Kontraktilität der Zelle (relative Zellverkürzung).

Welche Rolle FKBP12.6 in der Genese der Herzinsuffizienz spielt, wird weiterhin kontrovers diskutiert. So erhöht die Abdissoziation des FKBP vom RyR durch FK506 oder PKAPhosphorylierung (siehe 1.4.3.) die Offenwahrscheinlichkeit des Kanals und verursacht lang anhaltende submaximale Leitfähigkeitszustände mit folgender Erhöhung der zytoplasmatischen $\mathrm{Ca}^{2+}$ - Konzentration (Kaftan et al. 1996, Marx et al. 2000), was die Arrhythmieneigung der Zelle begünstigt. Dies konnte auch durch Untersuchungen mit FKBP12.6-Knockout-Mäusen bestätigt werden, die keine Zeichen einer Herzinsuffizienz, jedoch Katecholamin-sensitive polymorphe ventrikuläre Tachykardien (CPVT) entwickelten (Wehrens et al. 2003).

Die gestörte Bindung von FKBP12.6 an den RyR2 bei PKA-Hyperphosphorylierung kann durch die Gabe von JVT519, einem Benzothiazepin, verbessert werden, wie neuere Untersuchungen (Wehrens et al. 2005, Lehnart et al. 2006) zeigen. Eine ß-adrenerge Blockade, ein etablierter pharmakologischer Therapieansatz bei Herzinsuffizienz, vermag ebenfalls die Stoichiometrie der RyR-assoziierten Proteine wiederherzustellen und damit den beobachteten $\mathrm{Ca}^{2+}$-Verlust zu beheben (Reiken et al. 2001, Doi et al. 2002). 
Inwiefern FKBP oder der RyR selbst von weiteren Proteinen beeinflusst werden und welche spezifische Rolle FKBP beim „coupled gating“ sowie der Herzinsuffizienz spielt, ist weiter Gegenstand derzeitiger Untersuchungen.

\subsubsection{RyR und Calcineurin}

Calcineurin ist eine zytoplasmatische, $\mathrm{Ca}^{2+} /$ Calmodulin-abhängige Serin-/ThreoninPhosphatase. Es wird ebenso wie die Gruppe der FKBP in nahezu allen Geweben und Organismen exprimiert und weist dabei kaum Strukturunterschiede auf. Calcineurin nimmt bei der Umsetzung von $\mathrm{Ca}^{2+}$-Signalen zu zellulären Antworten (z.B. Genexpression) eine zentrale Rolle ein (Crabtree 1999). Am besten ist seine Funktion innerhalb der Immunantwort in T-Zellen bekannt. Vermittelt durch steigende, intrazelluläre $\mathrm{Ca}^{2+}$-Konzentrationen dephosphoryliert Calcineurin Transkriptionsfaktoren aus der Familie der NF-AT (nukleäre Faktoren aktivierter T-Zellen), wodurch deren Translokation zum Nukleus und infolge die Expression des Zytokins Interleukin 2 (IL2) ermöglicht wird (Clipstone und Crabtree 1992). IL 2 stimuliert die Aktivierung und Proliferation der T-Zellen.

Die Immunsuppressiva FK506 und Cyclosporin A im Komplex mit ihren jeweiligen intrazellulären Rezeptoren, FKBP bzw. Cyclophylin, binden Calcineurin und inhibieren dessen Phosphataseaktivität (Liu et al. 1991). Durch die fehlende Dephosphorylierung verbleibt NF-AT im Zytosol. Die Transkription von IL2 und damit die Immunanwort werden unterdrückt.

Neben den bekannten Aufgaben Calcineurins wird dessen Rolle in der Genese der kardiogenen Hypertrophie und Herzinsuffizienz diskutiert. Die Calcineurinaktivität ist in hypertrophierten Ventrikeln nach Aorten-Banding 3,2fach erhöht (Lim et al. 2000). Calcineurin-überexprimierende Mäuse entwickeln eine schwere Herzhypertrophie mit dem entsprechenden fetalen Genexpressionsmuster, d.h. dass BNP („brain natriuretic peptid“), ßMyosinschwerkette ( $\beta$-MHC) und $\alpha$-skelettales Aktin herauf- und $\alpha$-MHC herabreguliert werden. Dem wird zu Grunde gelegt, dass Calcineurin bei anhaltend erhöhten $\mathrm{Ca}^{2+}$-Spiegeln im Zytosol aktiviert wird (Dolmetsch et al. 1997) und NF-AT3 dephosphoryliert, das sich dann zusammen mit dem Traskriptionsfaktor GATA4 im Zellkern verbindet und die Transkription von Hypertrophie-charakteristischen Genen wie BNP einleitet (Molkentin et al. 1998). Ob die Behandlung mit Calcineurinantagonisten wie FK506 und Cyclosporin A (CsA) eine Rückbildung der Hypertrophie bewirkt, ist umstritten (Sussman et al. 1998, Zhang W et al. 1999) ebenso wie die Frage, ob die Achse Calcineurin - NF-AT die einzige Endstrecke vieler hypertrophieinduzierender Stimuli darstellt oder andere Bindungspartner für 
Calcineurin wie z.B. der Transkriptionsfaktor MEF2 (Passier et al. 2000) bzw. völlig andere Signalwege existieren (Olson und Molkentin 1999, Olson und Williams 2000).

Die Interaktion Calcineurins mit den $\mathrm{Ca}^{2+}$-Freisetzungskanälen RyR und IP3R ist Gegenstand derzeitiger Forschung. Cameron et al. konnten bereits 1995 mittels CoImmunopräzipitationsuntersuchungen zeigen, dass Calcineurin an den IP3R gebunden wird. In der selben Arbeit wurde ebenfalls eine Interaktion von Calcineurin mit dem RyR gezeigt. In beiden Fällen führte selektiv FK506, aber nicht Cyclosporin A zu einem Verlust dieser Bindung, was nahe legt, dass eine Verankerung von Calcineurin an den jeweiligen Kanal FKBP-vermittelt erfolgt. Zudem wurde gezeigt, dass Calcineurin den Phosphorylierungsstatus des IP3R und damit dessen $\mathrm{Ca}^{2+}$-Freisetzungsaktivität reguliert. Dabei ist die Komplexbildung zwischen RyR-FKBP-Calcineurin beziehungsweise IP3R-FKBP-Calcineurin $\mathrm{Ca}^{2+}$-abhängig und unterbleibt in Anwesenheit von $\mathrm{Ca}^{2+}$-Chelatbildnern wie EDTA (Cameron et al 1995). Diese Tatsache fügt sich gut in die Erkenntnisse von Bezprozvanny et al. (1991) sowie Iino und Tsukioka (1994), nach denen die $\mathrm{Ca}^{2+}$-Freisetzung über den IP3R nach Stimulation mit dessen Liganden Inositol-1,4,5-Trisphosphat (IP3) eine glockenkurvenförmige Abhängigkeit von der $\mathrm{Ca}^{2+}$-Konzentration aufweist. In einer späteren Arbeit von Bandyopadhyay et al. (2000) konnte spezifisch die FKBP12.6-vermittelte Bindung von Calcineurin an den RyR der Herzmuskelzelle nachgewiesen werden. Eine Abhängigkeit von der zytosolischen $\mathrm{Ca}^{2+}$ Konzentration zeigte sich auch hier. Eine FK506-vermittelte Abdissoziation des FKBP/Calcineurin-Komplexes vom RyR führte zu vermehrten spontanen $\mathrm{Ca}^{2+}-$ Strömen, die aber auch durch Cyclosporin A induziert werden konnten. Da Cyclosporin A lediglich zu einer Inhibition der Phosphataseaktivität des Calcineurins führt und die Bindung von FKBP/Calcineurin am RyR nicht beeinflusst, legt dies nahe, dass Calcineurin eine wichtige Rolle bei der FKBP-vermittelten Stabilisierung des Kanals spielt. Calcineurin kann aber lediglich in einer an den RyR gebundenen Form dessen Phosphorylierungsstatus beeinflussen, was durch Versuche mit Rapamycin gezeigt werden konnte. Rapamycin vermag den FKBPCalcineurin-Komplex aus der Bindung am RyR zu lösen, kann aber die Calcineurinaktivität nicht inhibieren. Dennoch fanden sich auch hier eine erhöhte Offenwahrscheinlichkeit des Kanals mit spontanen $\mathrm{Ca}^{2+}$-Freisetzungen.

Zusammenfassend lassen diese Beobachtungen einen Einfluss von Calcineurin bei der Regulation der $\mathrm{Ca}^{2+}$-Freisetzung über den RyR vermuten. 


\subsection{Herzinsuffizienz}

\subsubsection{Definition und Ätiologie}

Herzinsuffizienz bezeichnet das Unvermögen des Herzens, trotz ausreichend venösem Blutangebot die adäquate Versorgung der Körpergewebe mit oxygeniertem Blut zu gewährleisten. Ätiologisch liegt dieser Erkrankung meist ein ischämisch bedingter Verlust von Myokard oder eine chronische Druck- und Volumenbelastung der Ventrikel (z.B. Hypertonie und Klappenvitien) zugrunde. Aber auch genetische, virale, autoimmune, metabolische und toxische Auslöser können eine Schädigung des Herzmuskels (z.B. dilatative Kardiomyopathie) und sekundär die Leistungseinschränkung des Organs verursachen. Ferner bedingen eine behinderte Füllung der Ventrikel (z.B. bei konstriktiver Perikarditis) und Rhythmusstörungen eine verminderte Auswurfleistung.

\subsubsection{Kompensationsmechanismen}

Bei einer Leistungseinschränkung des Herzmuskels stehen dem Körper zur Aufrechterhaltung des adäquaten arteriellen Mitteldrucks und damit einer ausreichenden Organperfusion verschiedene Kompensationsmechanismen zur Verfügung, die ineinander verzahnt sind und sich gegenseitig bedingen.

Bei verminderter Auswurfleistung wird durch die Steigerung des Sympathikotonus und damit der $\beta$-adrenergen Stimulation am Herzen die Kraftentwicklung (Inotropie), die Schlagfrequenz (Chronotropie), die Überleitungszeit einer Erregung auf den Ventrikel (Dromotropie) sowie die Relaxationszeit (Lusitropie) verbessert (Brodde 1991). Zusätzlich führt die schnellere Herzfrequenz katecholaminunabhängig zu einer positiven Inotropie, die auch als Frequenzinotropie oder Bowditch-Phänomen bezeichnet wird (Bowditch 1871, Piot et al. 1996).

Endogene Peptide spielen bei der Kompensation der Kraftminderung ebenfalls eine wichtige Rolle. Vermittelt über den verminderten peripheren Perfusionsdruck und den erhöhten Sympatikotonus erfolgt die Aktivierung des Renin-Angiotensin-Aldosteron-System (RAAS). Angiotensin II ist dabei über die Stimulation von $\mathrm{AT}_{1}$-Rezeptoren ein starker Vasokonstriktor und bewirkt die Freisetzung von Aldosteron, das die renale Natrium- und Wasserretention steigert. Dementsprechend erhöhen sich Vor- und Nachlast der Ventrikel. Ferner steigt bei Herzinsuffizienz die Plasmakonzentration von Endothelin, das ähnlich Angiotensin II und Katecholaminen eine periphere Vasokonstriktion bewirkt (Yanagisawa et al. 1988) und am Herzen direkt positiv inotrop wirkt (Pieske et al. 1999). 
Eine Steigerung des diastolischen Füllungsdruckes (Vorlast) erhöht innerhalb physiologischer Grenzen über zunehmende Vordehnung die Kontraktilität der Muskulatur und wird als FrankStarling-Mechanismus bezeichnet (Frank 1895, Gordon et al. 1966). Durch die verstärkte Sarkomerdehnung wird die Überlappung der Myofilamente verbessert, die $\mathrm{Ca}^{2+}$-Sensitivität (vor allem von Troponin) erhöht sowie die $\mathrm{Ca}^{2+}$-Transienten gesteigert (Allen und Kentish 1988, Gulati 1992).

Sowohl die andauernde Stimulation der $\beta_{1^{-}}$und $\mathrm{AT}_{1}$-Rezeptoren als auch die proliferativen Effekte von Endothelin und Zytokinen wie Tumornekrosefaktor $\alpha$ bewirken eine Hypertrophie des Herzens mit gesteigerter intrazellulärer Proteinsynthese sowie Fibroblastenproliferation mit vermehrter Kollagensynthese extrazellulär, die zusammen die Leistungsfähigkeit des Myokards erhöhen sollen (Engelhardt et al. 1999, Yamazaki et al. 1995, Yokoyama et al. 1997, Ito et al. 1991).

\subsubsection{Dekompensation}

Kurzfristig kann so die verminderte Leistungsfähigkeit des Myokards kompensiert werden. Besteht die Schädigung aber über einen längeren Zeitraum hin, ergibt sich ein Circulus vitiosus, der in einer manifesten, chronischen Herzinsuffizienz mündet.

Bei andauernder sympatischer Stimulation kommt es zu einer Desensibilisierung und folgend zur Dichteabnahme vornehmlich der $\beta_{1}$-Rezeptoren um bis zu 50\% mit dadurch bedingter verminderter Ansprechbarkeit auf Katecholamine (Bristow et al. 1982 und 1986). Zusätzlich wird am insuffizienten Herzen eine verminderte bis aufgehobene Frequenzinotropie gefunden (Mulieri et al. 1992). Ob der Frank-Starling-Mechanismus in chronisch insuffizienten Herzen einen verminderten Einfluss auf die Kontraktilität besitzt, wird kontrovers diskutiert. (Schwinger et al. 1994, Holubarsch et al. 1996).

Vor- und Nachlaststeigerung sowie Hypertrophie bedingen erhöhte Wandspannungen und Füllungsdrücke, wodurch die diastolische Koronarperfusion abnimmt. Dementsprechend wird das intakte Myokard trotz Mehrarbeit minderversorgt und geschädigt. Zusätzlich besitzen Sauerstoffradikale, die vermehrt durch Ischämie entstehen, aber auch Angiotensin II und Zytokine am Herzen zytotoxische Effekte, die zu Apoptose führen (Feuerstein und Young 2000). Ob sie ebenfalls für die Fibrose des insuffizienten Herzens verantwortlich sind, konnte bis zum jetzigen Zeitpunkt nicht eindeutig nachgewiesen werden.

Auf zellulärer Ebene kommt es zur nachhaltigen Störung des $\mathrm{Ca}^{2+}$-Haushalts mit verringertem SR-Ca ${ }^{2+}$-Gehalt (Piacentino et al. 2003). Dieser Beobachtung liegt unter anderem eine verminderte Expression der SERCA zu Grunde (Hasenfuss et al. 1994), die zu einer 
herabgesetzten $\mathrm{Ca}^{2+}$-Wiederaufnahme des SR führt. Zusätzlich ist die Expressionsrate von Phospholamban nur schwach verringert, so dass seine SERCA inhibierende Funktion stärker zum Tragen kommt (Hasenfuss et al. 1997). Dem gegenüber steht eine erhöhte Synthese und Aktivität des NCX (Studer et al. 1994), aus der eine vermehrte Elimination von $\mathrm{Ca}^{2+}$ nach extrazellulär resultiert. Andererseits wurde ein $\mathrm{Ca}^{2+}$-Einwärtsstrom über den NCX (,,reverse mode") in insuffizienten Myozyten beschrieben, der die Dauer des Aktionspotentiales und den Abfall des $\mathrm{Ca}^{2+}$-Transienten verlängert (Dipla et al 1999, Weber et al. 2003).

Ferner wurde in insuffizienten Kardiomyozyten eine Hyperphosphorylierung des RyR durch PKA beschrieben. Dies bedingt zum einen eine erhöhte $\mathrm{Ca}^{2+}$-Sensitivität des RyR mit Kanalaktivierung bei geringeren zytosolischen $\mathrm{Ca}^{2+}$-Konzentrationen. Zusätzlich wird durch eine Abdissoziation von FKBP12.6 die Stabilität des einzelnen RyR gestört und der RyRVerband funktionell entkoppelt. Dies bedingt eine erhöhte Offenwahrscheinlichkeit des Kanals und einen gesteigerten $\mathrm{Ca}^{2+}$-Verlust $\left(, \mathrm{Ca}^{2+}\right.$-Leak“) aus dem SR in der Diastole, die zur Depletion des SR beitragen (Marx et al. 2000, Yano et al. 2000).

Der herabgesetzte SR-Ca ${ }^{2+}$-Gehalt, die ineffektive $\mathrm{Ca}^{2+}$-Freisetzung über den Verband der RyR und die nominelle Verschiebung von $\mathrm{Ca}^{2+}$ nach extrazellulär sind Grundlage der verminderten Kontraktionskraft der insuffizienten Herzmuskelzelle (Bers et al. 2003, Hasenfuss und Seidler 2003). Der anhaltend erhöhte zytoplasmatische $\mathrm{Ca}^{2+}$-Gehalt erhöht die Gefahr des Auftretens lebensbedrohlicher Arrhythmien (Pogwizd et al.1999).

\subsection{Vorarbeiten: Viruskonstrukt}

Adenoviren (Ad) verursachen bevorzugt akute respiratorische Infekte, Konjunktivitiden und Diarrhoen. Ihre Hülle, ein Proteincapsid, umgibt eine Doppelstrang-DNA aus etwa 36000 Basenpaaren (bp). Viren sind keine Lebewesen und können sich nur mit Hilfe von Wirtszellen replizieren, wofür das gesamte Erbgut des Virus in den Zellkern eingebracht werden muss. Adenoviren infizieren die Wirtszelle, indem sie an den Coxsackievirus-Adenovirus-Rezeptor binden (Bergelson et al. 1997) und nach Anheftung an die Wirtsmembran mit einem zweiten Rezeptor, avß-Integrin, interagieren, wodurch Endozytose und Transport bis zum Nukleus eingeleitet werden (Wickham et al. 1993). Dort gelangt nur ihre DNA bis in den Zellkern und wird transkribiert. Durch diese Eigenschaft und die leichte Modifizierbarkeit ihres Erbguts stellen sie eine Möglichkeit dar, auf gentechnischem Wege durch Überexpression die Aufgaben eines Transgens aufzuklären.

Die Gruppe der Adenoviren wird in 49 Serotypen geteilt, von denen vor allem Typ 5 und 2 für gentechnische Zwecke genutzt werden, da sowohl DNA-Sequenz als auch 
Replikationszyklus vollständig bekannt sind und sie in hohen Konzentrationen angezüchtet werden können.

Zur Konstruktion von rekombinanten Adenoviren wird ein DNA-Plasmid aus Escherichia coli verwendet, das einen Teil der Virus-DNA enthält. Um eine unkontrollierte Vermehrung der Viren zu verhindern, werden die Teile des Virusgenoms, die für Replikation des Virus verantwortlich sind (E1), entfernt. An Stelle dieses Genabschnitts wird eine Expressionskassette bestehend aus einem CMV-Promotor, dem zu transfizierenden Gen mit einem Splicing-Signal und ein Polyadenyl-Stop-Signal einligiert. Dazu werden das Plasmid und die Virus-DNA, in der die Anfangssequenz fehlt, zusammen in eine Zellinie, bestehend aus humanen embryonalen Nierenzellen (293-Zellen), kotransfiziert. Die 293-Zellen exprimieren das zur Virus-Replikation fehlende E1-Protein (Graham et al. 1977). Durch rekombinante DNA-Plasmide entstehen so auf HEK293-Zellen infektiöse, replikationsinkompetente Adenoviren. Das gewünschte Gen ist im Erbgut integriert und kann an Zellen durch Infektion weitergeben werden. Eine eigenständige Replikation ist aber ohne eine E1-Expression von extern nicht möglich. Der so generierte Virus wird als Ad-x benannt, wobei x für das ins Virusgenom integrierte Gen steht.

Herzmuskelgewebe und isolierte Kardiomyozyten können in vitro leicht durch Adenoviren infiziert werden und zeigen hohe Expressionsraten des transfizierten Gens. Die Transfektion durch das Virus und die Expression der eingebrachten Gene hat erfahrungsgemäß keinen signifikanten Einfluss auf die Kontraktilitätsparameter der Zellen (Lehnart et al. 2000).

Problematisch für die Nutzung des adenoviralen Gentransfers in der Gentherapie ist die Dauer der Expression des transfizierten Gens sowie immunologische Phänomene. Nach einer maximalen Syntheserate zwischen dem ersten und siebten Tag, fällt sie bis zur vierten Woche, wahrscheinlich auf Grund von Immunabwehr und Absterben der Wirtszellen, auf nicht detektierbare Level. Ferner wird eine ausreichende Transfektionsrate in vivo bei den meisten Geweben nur durch lokale Applikation erreicht, während nach intravenöser Applikation das Virus hauptsächlich in Leber und Milz aus dem Blut absorbiert wird. Sollten diese Nachteile behoben werden, könnte der Gentransfer mit Hilfe von Adenoviren eine Möglichkeit zur Therapie von genetisch bedingten oder modifizierten Erkrankungen darstellen. Derzeit stellt adenoviraler Gentransfer jedoch lediglich ein effektives Mittel zum Zweck der experimentellen Transfektion von Kardiomyozyten dar, die sich mit konventionellen Verfahren wie Lipofektion oder Elektroporation nicht hinreichend transfizieren lassen. 


\subsection{Fragestellung}

Die Funktionen von FKBP12.6 in Verbindung mit dem RyR2 war Gegenstand intensiver Forschungsarbeit der letzten Jahre. Aus Überexpressionsstudien ist bekannt, dass FKBP12.6 in der Herzmuskelzelle den RyR in einer geschlossenen Konformation stabilisiert und so zu einer herabgesetzten Offenwahrscheinlichkeit des Kanals mit konsekutiv vermindertem Verlust von $\mathrm{Ca}^{2+}$ in der Diastole führt. Dies sowie die koordiniertere Öffnung der RyR in der Systole bedingen eine verbesserte Kontraktilität der Zellen. Der RyR als größter bekannter Ionenkanal besitzt eine Vielzahl von Bindungsstellen für regulatorische Proteine, wobei deren genaue Anzahl nicht bekannt ist. Eine Interaktion der Proteinphosphatase Calcineurin mit FKBP und RyR konnte bereits gezeigt werden (Cameron et al. 1995). Ungeklärt ist aber, ob diese mögliche Interaktion auch funktionell von Bedeutung ist.

Die Fragestellungen dieser Arbeit waren demzufolge:

- Kann über die gezielte Veränderung des FKBP12.6-Gens eine Calcineurinbindungsdefiziente Mutante (FKBP12.6 $\left.6^{\mathrm{G} 89 \mathrm{PV} 90 \mathrm{~K}}\right)$ generiert werden?

- Ist es möglich, dieses Protein in Kardiomyozyten mit Hilfe des adenoviralen Gentransfers zu exprimieren?

- Hat der Verlust der Calcineurinbindungsfähigkeit Auswirkungen auf andere Eigenschaften des FKBP12.6 wie die Rotamaseaktivität?

- Hat der Verlust der Calcineurinbindungsfähigkeit des FKBP12.6 einen Einfluss auf dessen regulierende Funktion für die $\mathrm{Ca}^{2+}$-Freisetzung über den RyR2 und damit auf die Kontraktilität der Herzmuskelzelle?

- Bietet der Verlust der Calcineurin-Bindungsfähigkeit einen möglichen Erklärungsansatz für die Genese der dekompensierten Herzinsuffizienz? 


\section{MAterial Und Methoden}

\subsection{DNA-Mutation}

Zur Erzeugung der Mutation G89PV90K in der humanen FKBP12.6-cDNA wurde das SiteDirected Mutagenesis Kit (Stratagene, Cedar Creek, USA) verwendet und nach den Angaben des Herstellers verfahren. Pro Ansatz wurden 100 ng Doppelstrang-DNA (dsDNA) zuerst durch Hitze denaturiert, um beide DNA-Stränge voneinander zu trennen. Folgend wurden die Einzelstränge mit Hilfe einer Polymerase (PfuTurbo ${ }^{\mathrm{TM}}$ DNA-Polymerase, Stratagene, Cedar Creek, USA) repliziert. Hierzu wurden zwei Oligonukleotidprimer verwendet, die jeweils die gewünschte Mutation enthielten und komplementär zu gegenüberliegenden Seiten des DNAStranges waren.

Folgend wurden aus der neu synthetisierten DNA die parentalen Anteile entfernt. Da die unmutierte DNA aus E.coli sich von neu synthetisierter DNA durch das Vorhandensein von Methylgruppen unterscheidet, ließ sie sich durch Verdau mit einer Endonuklease (Dpn I Endonuklease, Stratagene, Cedar Creek, USA), die spezifisch nur methylierte DNA fragmentiert, abbauen. Abschließend wurde die mutierte dsDNA in XL1-Blue Supercompetent cells (Stratagene, Cedar Creek, USA) überführt. Die DNA-Klone wurden im Midi Präp-Verfahren (Qiagen GmbH, Hilden, D) nach Angaben des Herstellers aufgereinigt und zum Nachweis der Sequenzintegrität im kodierenden Bereich sequenziert (MWG Biotech, Ebersberg).

\subsection{Herstellung rekombinanter Proteine}

\subsubsection{Klonierung und Kultur}

Bevor der Einfluss eines calcineurinbindungsdefizienten FKBP12.6 auf Calciumhaushalt und Kontraktionsverhalten in der Herzmuskelzelle via adenoviralem Gentransfer untersucht werden konnte, wurde zuvor durch Calcineurin- und Rotamase-Assay verifiziert, ob die Mutationen G89P und V90K in FKBP12.6 einen Affinitätsverlust für Calcineurin bei erhaltener FK506-Inhibierbarkeit verursachen.

Zur Herstellung der für die Assays verwendeten rekombinanten Proteine wurde cDNA, kodierend für FKBP12.6 sowie für FKBP12.6 ${ }^{\mathrm{G} 89 \mathrm{PV} 90 \mathrm{~K}}$, mittels $\mathrm{PCR}$ amplifiziert. Dafür wurden Primer verwendet, die 5'- wie 3'-wärts des Leserahmens eine Bbs I-Schnittstelle 
erzeugten. In für FKBP12.0 kodierende cDNA wurden durch PCR-Amplifikation Bsa ISchnittstellen eingeführt. Die amplifizierte cDNA für FKBP12.0, FKBP12.6 und FKBP12.6 ${ }^{\mathrm{G} 89 \mathrm{PV} 90 \mathrm{~K}}$ wurde über die genannten Schnittstellen in den Vektor pASK IBA7 (IBA, Göttingen) einligiert. Der Vektor enthält eine Ampicillinresistenz-Kassette. Die Proteinexpression steht unter der Kontrolle eines tetA-Operators, der in Abwesenheit des Induktors (Anhydrotetrazyklin) inhibiert wird. Durch die leserahmenerhaltende Ligation über BbsI/BsaI wurde die FKBP-cDNA 5'-wärts mit einer Strep-tag-Sequenz verbunden (Strep-tag II, IBA, Göttingen). Beim Strep-tag handelt es sich um ein Peptid, das aufgrund seiner biotinähnlichen Eigenschaften von StrepTactin gebunden wird. FKBP wird mit dem Nterminalen Strep-tag II (Sequenz: $\mathrm{NH}_{2}$-Trp-Ser-His-Pro-Gln-Phe-Glu-Lys-COOH) als Fusionsprotein exprimiert.

Die Vektoren wurden durch Elektroporation in E.coli (Stamm XL1-Blue) eingebracht. Aus ampicillinresistenten Einzelkolonien wurde mit genspezifischen Primern ein positiver Klon identifiziert und für etwa 16 Stunden in einer LB-Amp-Kultur (siehe 2.11.1., Seite 34) bei 200 $\mathrm{U} / \mathrm{min}$ und $37^{\circ} \mathrm{C}$ im Schüttelinkubator bebrütet. Aus $4 \mathrm{ml}$ dieser Kultur wurden Glycerolstocks hergestellt.

\subsubsection{Expressionskultur}

Aus den unter 2.2.1. genannten Glycerolstocks wurden Einzelkolonien selektiert und in einer Vorkultur (5 ml LB-Amp) bei $37^{\circ} \mathrm{C}$ für 16 Stunden inkubiert. $2 \mathrm{ml}$ dieser Vorkultur wurden in $100 \mathrm{ml}$ vorgewärmtes LB-Amp überführt und der Ansatz bei $37^{\circ} \mathrm{C}$ und $200 \mathrm{U} / \mathrm{min}$ für etwa 2 Stunden im Schüttelinkubator bebrütet bis die Absorption bei $550 \mathrm{~nm} \mathrm{0,5}$ betrug. Nach Erreichen dieses Wertes wurde die Transkription durch Zugabe von $10 \mu$ l Anhydrotetrazyklin ( $2 \mathrm{mg} / \mathrm{ml}$ ) induziert und die Kultur weitere 3 Stunden bei $30{ }^{\circ} \mathrm{C}$ inkubiert. Alle 30 Minuten wurde ein 50 $\mu$ l-Aliquot zur späteren SDS-PAGE-Analyse entnommen.

Nach Ablauf der Inkubationszeit wurde der Ansatz bei $4^{\circ} \mathrm{C}$ und $4000 \mathrm{U} / \mathrm{min}$ für $15 \mathrm{~min}$ zentrifugiert, der Überstand verworfen und das Pellet bis zur weiteren Verwertung bei $-20^{\circ} \mathrm{C}$ aufbewahrt.

\subsubsection{Affinitätsaufreinigung}

Da die rekombinanten Proteine zusammen mit Strep-tag II, einem Biotin-ähnlichen, selektiv StrepTactin bindenden Protein, als Fusionsprotein exprimiert wurden, war es möglich, sie über StrepTactin-Matrizes (IBA GmbH, Göttingen) affinitätschromatographisch aufzureinigen. 
Dazu wurden alle Arbeiten bei $4^{\circ} \mathrm{C}$ durchgeführt. Zuerst wurden die entsprechenden Bakterienpellets (siehe 2.2.2.) mit $1 \mathrm{ml}$ Puffer W (2.11.1., Seite 34) resuspendiert und zur vollständigen Lysierung sonifiziert. Durch Zentrifugation bei 14000 U/min für 15 min wurden die unlöslichen Bestandteile und Zellorganellen von der zytoplasmatischen Proteinfraktion im Überstand abgetrennt.

Die zur Aufreinigung benötigte Gelmatrix (StrepTactin-Sepharose, IBA, Göttingen) wurde nach Anleitung des Herstellers in Polystyren-Säulen (Pierce, Bonn) gegossen. Vor jeder Nutzung wurden die Säulen mit 2 x 2,5 ml Puffer W äquilibriert, anschließend je $1 \mathrm{ml}$ der Proteinsuspension aufgetragen. Durch Waschschritte mit 5 x $1 \mathrm{ml}$ Puffer W wurden alle nicht bindenden Lysatbestandteile aus der Säulenmatrix entfernt. Um das rekombinante Protein im Folgenden selektiv auszulösen, wurden 6 x 0,5 ml Puffer E (2.11.1., Seite 34) hinzugegeben, da das enthaltene Desthiobiotin kompetitiv die StrepTactin-Bindungsstellen besetzt und den Strep-tag II des Fusionsproteins von dort verdrängt. Alle Wasch- und Elutionsfraktionen wurden entsprechend der auf die Säulen gegebenen Volumen aufgefangen und nach Abnahme eines $8 \mu$-Aliquots für SDS-PAGE-Analyse bei $-20^{\circ} \mathrm{C}$ aufbewahrt. Die Säulen konnten nach entsprechender Regeneration (3 x 5 ml Puffer R, 2.11.1., Seite 34) wieder verwendet werden.

\subsubsection{SDS-Polyacrylamid-Gelelektrophorese (SDS-PAGE)}

Um die Reinheit der rekombinanten Proteine zu bestimmen und zur Identifikation der Fraktionen mit hohen Konzentrationen rekombinanten Proteins, erfolgte eine elektrophoretische Auftrennung der Fraktionen-Aliquots nach der Methode von Laemmli (1970). Dazu wurden konventionelle 12,5\%ige SDS-Polyacrylamidgele verwendet (Zusammensetzung siehe Tab. 1). Die noch flüssige Suspension wurde in die Gelkammern eines Mini Protean II (Bio Rad, München) gegossen und, um ein Austrocknen zu verhindern, mit $\mathrm{H}_{2} \mathrm{O}$-gesättigtem Butanol überschichtet. Nach Verfestigung der Gelmatrix wurde das Butanol wieder entfernt, das Sammelgel (siehe Tab.1) aufgegossen und ein Kamm zur Taschenbildung eingesetzt. Nachdem auch hier die Gelmatrix verfestigt war, wurden die Gele in die Laufkammern eingespannt und die Kämme entfernt.

Zum Auftragen der Proben wurden je $8 \mu \mathrm{l}$ der Wasch- und Elutionsfraktionen mit $2 \mu 1$ Proben-Puffer (2.11.1., Seite 34) versetzt, bei $95^{\circ} \mathrm{C}$ für $10 \mathrm{~min}$ erhitzt und nach Auffüllen der Elektrophoresekammer mit Laufpuffer (2.11.1., Seite 34) in die Taschen des Sammelgels gegeben. Die Laufzeit der Proben betrug eine Stunde bei 50 mA. Als Größenmarker wurden $20 \mu \mathrm{l}$ eines vorgefärbten Proteinstandards (Precision Protein Standards, BioRad) verwendet. 


\begin{tabular}{|l|c|c|c|}
\hline Reagenzien & Trenngel (hochauflösend) 12,5\% & Trenngel (konventionell)12,5\% & Sammelgel \\
\hline $30 \%$ Acrylamid & $4,17 \mathrm{ml}$ & $4,17 \mathrm{ml}$ & $0,67 \mathrm{ml}$ \\
\hline $\begin{array}{l}\text { 4X Tris/SDS- Puffer } \\
\text { pH } 8,8\end{array}$ & $2,5 \mathrm{ml}$ & $2,5 \mathrm{ml}$ & $\mathbf{p H ~ 6 , 8 ~} 1,25 \mathrm{ml}$ \\
\hline $\mathrm{H}_{2} \mathrm{O}$ & $3,2 \mathrm{ml}$ & $3,33 \mathrm{ml}$ & $3,08 \mathrm{ml}$ \\
\hline TEMED & $0,025 \mathrm{ml}$ & $0,007 \mathrm{ml}$ & $0,010 \mathrm{ml}$ \\
\hline APS $10 \%$ & $0,250 \mathrm{ml}$ & $0,033 \mathrm{ml}$ & $0,030 \mathrm{ml}$ \\
\hline
\end{tabular}

Tab. 1: Zusammensetzung der Trenn- und Sammelgele

Um die Proteine im Gel anzufärben, erfolgte eine einstündige Inkubation in CoomassieBrilliant-Blue-Lösung (Coomassie ${ }^{\circledR}$ Brilliant Blue G-250, BioRad, München) und eine anschließende Entfärbung des Hintergrundes in $10 \mathrm{ml}$ Entfärbelösung (2.11.1., Seite 34) für circa 12 Stunden. Die Gele wurden im Anschlußss getrocknet (Dry Ease ${ }^{\mathrm{TM}}$, Novex) und fotografiert.

Einige Proben wurden abweichend vom obigen Protokoll auf hochauflösenden $12.5 \%$ igen Gelen getrennt (siehe Tab. 1), durch die es möglich ist, einzelne FKBP-Varianten voneinander zu diskriminieren (Timerman et al. 1994). Die Elektrophorese erfolgte bei 30 mA (1 Gel) bis die Laufgrenze den unteren Rand des Gels erreicht hatte. Im Anschluss wurden die Gele ebenfalls gefärbt und digitalisiert.

Gleichermaßen wurden zur Veranschaulichung der Proteinexpressionszunahme unter Inkubation je $8 \mu \mathrm{l}$ der entnommen Proben (siehe 2.2.2.) der Expressionskultur elektrophoretisch auf konventionellen 12,5\%igen Polyacrylamidgelen aufgetrennt und wie unter 2.9.3. (Seite 32) beschrieben weiterverarbeitet.

\subsubsection{Proteinbestimmung}

Die Bestimmung des Proteingehaltes der Elutionsfraktionen, die laut SDS-PAGE-Analyse rekombinantes Protein enthielten, erfolgte durch den quantitativen Nachweis reduzierter $\mathrm{Cu}^{2+}$ Ionen über einen Bicinchoninsäure-basierten Assay (BCA Protein Assay, Pierce, Bonn). Die Absorption jeder behandelten Probe wurde photometrisch bei $562 \mathrm{~nm}$ gemessen und die jeweilige Proteinkonzentration mittels Extrapolation mit Hilfe einer aus Rinderserumalbumin (Albumin Standard, Pierce, Bonn) erstellten Standardregressionsgerade ermittelt. 


\subsection{Calcineurinaffinitäts-Assay}

Zum quantitativen Nachweis der Calcineurinbindungsaktivität der rekombinanten Proteine wurde ein kommerzieller Assay (BIOMOL GREEN ${ }^{\mathrm{TM}}$ Calcineurin-Assay, BIOMOL, Hamburg) verwendet, der auf dem Nachweis freien Phosphats beruht, das aus einem Phosphopeptid-Substrat $\quad\left(\mathrm{NH}_{2}\right.$-Asp-Leu-Asp-Val-Pro-Lle-Pro-Gly-Arg-Phe-Asp-Arg-ArgVal-pSer-Val-Ala-Ala-Glu-COOH) durch Calcineurin abgespalten wird. Die freigesetzte Phosphatmenge wird durch die Farbreaktion einer Detektionslösung (BIOMOL GREEN ${ }^{\mathrm{TM}}$ ) photometrisch messbar gemacht. Im Komplex mit FKBP und FK506 wird die Phosphataseaktivität von Calcineurin inhibiert (Liu et al. 1991). Durch die fehlende Calcineurinaffinität des mutierten FKBP12.6 sollte entsprechend die Inhibition von Calcineurin ausbleiben.

Dazu wurden auf einer Mikrotiterplatte (Costar, Bodenheim) zu $25 \mu 1$ des Calcineurin-AssayPuffers (2.11.2., Seite 35) 40 IE rekombinantes Calcineurin (1 IE = $1 \mathrm{pmol} / \mathrm{min}$ ) und $320 \mathrm{ng}$ des $\mathrm{zu}$ untersuchenden rekombinanten FKBP sowie variable Konzentrationen FK506 beigefügt. Nach 20 min Äquilibrierung bei $30^{\circ} \mathrm{C}$ wurde die Reaktion durch Zugabe von $10 \mu 1$ 0,75 mM Phosphopeptid-Substrat gestartet und nach 90 min durch jeweils $100 \mu$ l BIOLMOL GREEN $^{\mathrm{TM}}$ terminiert. Die Zusammensetzung der einzelnen Proben- und Kontrollansätze ist aus Tab. 2 ersichtlich. Alle Messungen erfolgten als Doppelbestimmungen. Es wurde eine Regressionsgerade aus seriellen 1:1 Verdünnungen des mitgelieferten Phosphatstandards beginnend mit $2 \mathrm{nmol}$ bis zu 0,031 nmol $\mathrm{PO}_{4}$ und einer $\mathrm{H}_{2} \mathrm{O}$-Kontrolle erstellt.

10 min nach Reaktionstermination wurde die Absorption der einzelnen Proben bei $620 \mathrm{~nm}$ photometrisch gemessen und mit Hilfe der Regressionsgerade die freigesetzten Phosphatmengen extrapoliert.

\begin{tabular}{|c|c|c|c|c|c|c|}
\hline Ansatz & $\begin{array}{l}\text { Calcineurin- } \\
\text { Assaypuffer }\end{array}$ & $\begin{array}{c}\text { Calcineurin } \\
(8 \mathrm{IE} / \mu \mathrm{l})\end{array}$ & $\mathrm{H}_{2} \mathrm{O}$ & $\begin{array}{c}\text { FKBP } \\
(10 \mu \mathrm{M})\end{array}$ & $\begin{array}{l}\text { FK506 } \\
(5 \mu \mathrm{M})\end{array}$ & $\begin{array}{l}\text { Phosphopeptid- } \\
\text { Substrat }(0,75 \mathrm{mM})\end{array}$ \\
\hline FKBP12.6 + FK506 & $25 \mu \mathrm{l}$ & $5 \mu \mathrm{l}$ & $0 \mu \mathrm{l}$ & $2 \mu \mathrm{l}$ & $8 \mu \mathrm{l}$ & $10 \mu \mathrm{l}$ \\
\hline $\begin{array}{l}\text { FKBP12.6 } \\
+ \text { FK59PV90K } \\
+ \text { 506 }\end{array}$ & $25 \mu \mathrm{l}$ & $5 \mu \mathrm{l}$ & $0 \mu \mathrm{l}$ & $2 \mu \mathrm{l}$ & $8 \mu \mathrm{l}$ & $10 \mu \mathrm{l}$ \\
\hline FK506 & $25 \mu \mathrm{l}$ & $5 \mu \mathrm{l}$ & $2 \mu \mathrm{l}$ & $0 \mu \mathrm{l}$ & $8 \mu \mathrm{l}$ & $10 \mu \mathrm{l}$ \\
\hline FKBP12.6 + $\mathrm{H}_{2} \mathrm{O}$ & $25 \mu \mathrm{l}$ & $5 \mu \mathrm{l}$ & $8 \mu \mathrm{l}$ & $2 \mu 1$ & $0 \mu \mathrm{l}$ & $10 \mu \mathrm{l}$ \\
\hline $\mathrm{FKBP} 12.6^{\mathrm{G} 89 \mathrm{PV} 90 \mathrm{~K}}+\mathrm{H}_{2} \mathrm{O}$ & $25 \mu \mathrm{l}$ & $5 \mu \mathrm{l}$ & $8 \mu \mathrm{l}$ & $2 \mu \mathrm{l}$ & $0 \mu \mathrm{l}$ & $10 \mu \mathrm{l}$ \\
\hline
\end{tabular}

Tab. 2: Pipettierschema der Ansätze des Calcineurinaffinitäts-Assays 


\subsection{Rotamase-Assay}

Die FK506-bindenden Proteine FKBP12.0 und FKBP12.6 können enzymatisch XProlinbindungen in Peptiden und Proteinen von einer cis- in eine trans-Konformation überführen, wobei $\mathrm{X}$ jede beliebige Aminosäure sein kann. Diese Eigenschaft wird als Peptidyl-prolyl-cis-trans-Isomeraseaktivität $\left(\mathrm{k}_{\mathrm{cat}}\right)$ oder kurz Rotamaseaktivität bezeichnet.

Diese Isomerisierung erfolgt auch spontan, ist aber durch die sehr niedrige Reaktionsgeschwindigkeit zu vernachlässigen.

Wenn sich Prolin an $\mathrm{P}_{2}$-Stellung eines Peptides, das heißt an zweiter Position vom CTerminus aus gezählt, mit einem endständigen $p$-Nitroanilin befindet, bindet $\alpha$-Chymotrypsin Prolin spezifisch in trans-Stellung und spaltet das $p$-Nitroanilin durch Hydrolyse ab (Fischer et al. 1984 a), was einen Farbumschlag der Lösung von farblos zu gelb bewirkt.

Dabei zeigt sich eine zweiphasige Kinetik mit einer schnellen Anstiegsphase, in der bereits vorliegende trans-Isomere schnell umgesetzt werden und die von der Chymotrypsinaktivität bestimmt wird. In einer zweiten Phase besteht der geschwindigkeitsbestimmende Schritt in der Überführung von cis- zu trans-Isomeren. Die zweite Phase zeigt eine Kinetik erster Ordnung und ist FKBP-abhängig.

Die Rotamaseaktivität der FKBP ist durch FK506 inhibierbar. Da die Bindung der Proteine an den Ryanodinrezeptor (RyR) wahrscheinlich über eine FK506-ähnliche Domäne erfolgt (Cameron et al. 1997), kann die Inhibierbarkeit der Rotamaseaktivität als ein Nachweis für die vorhandene Bindungsaffinität an den RyR gewertet werden. Über den Nachweis der durch FK506-Zugabe inhibierten Rotamaseaktivität lässt sich zudem ausschließen, dass die ausbleibende Calcineurininhibition des FKBP12.6 $6^{\mathrm{G} 89 \mathrm{PV} 90 \mathrm{~K}}$ auf einen Affinitätsverlust für FK506 zurückzuführen ist.

Der beschriebene Nachweis der Rotamaseaktivität beruht auf der Methode von Fischer et al. (1984 b) mit einigen Modifikationen. Dazu wurde eine $180 \mu \mathrm{M}$ Lösung des Peptides (SucAla-Leu-Pro-Phe-p-nitroanilid, Bachem, Heidelberg) in Rotamase-Assay-Puffer (2.11.3., Seite 35) hergestellt. Je $915 \mu \mathrm{l}$ der Peptidlösung wurden in einer auf $10^{\circ} \mathrm{C}$ temperierten Halbmikroküvette mit aufsteigenden Konzentrationen von FK506 versetzt (0, 95, 142, 190, 380 und $474 \mathrm{nM}$ ) und die zu untersuchende FKBP-Variante addiert. Nach Inkubation für 2 min wurden $500 \mu \mathrm{g}$ Chymotrypsin, gelöst in $1 \mathrm{mM} \mathrm{HCl}$, schnell hinzupipettiert und die sich entwickelnde Farbreaktion bei einer Wellenlänge von $410 \mathrm{~nm}$ mit einem Spektrophotometer (Cary 50, Varian, Palo Alto, USA) durch vom Hersteller mitgelieferte Software verfolgt und aufgezeichnet. Untersucht wurden die Proteine FKBP12.6 und FKBP12.6 ${ }^{\mathrm{G} 89 \mathrm{PV} 90 \mathrm{~K}}$ mit einer 
Endkonzentration im Assay von $125 \mathrm{nM}$. Zur Kontrolle wurden Ansätze ohne FKBP untersucht, das mit entsprechenden Volumina Puffer W (siehe 2.11.1., Seite 34) ersetzt wurde. Die aufgezeichneten Reaktionskurven wurden auf die Asymptote der Reaktionskurve normalisiert und zur qualitativen Analyse graphisch dargestellt.

\subsection{Myozytenisolation}

Die Isolation von Myokardzellen des Kaninchens erfolgte gemäß den Tierschutzbestimmungen und nach Genehmigung durch die Ethikkommission der Universität Göttingen.

FKBP12.6 $6^{\mathrm{G} 89 \mathrm{PV} 90 \mathrm{~K}}$ wurde durch adenoviralen Gentransfer in isolierten Herzmuskelzellen überexprimiert. Die Einzelzellen wurden aus Herzen weiblicher, 2-2,5 kg schwerer, adulter Kaninchen der Rasse Chinchilla Bastard (Charles River, Sulzfeld) isoliert. Dazu wurden die Tiere zuerst mit 1000 IE Heparin i.v. antikoaguliert, um intrakoronare, post mortem entstehende Thromben zu verhindern, die zu Perfusionsbehinderungen im Myokard und damit zu Ischämien und unzureichender Lyse der Zellkontakte beim Kollagenaseverdau führen können. Im Anschluss wurden die Kaninchen mit 50 mg/kgKG Thiopental i.v. narkotisiert. Bei Erreichen der gewünschten Narkosetiefe (Atemstillstand, Erschlaffung der Muskulatur, negativer Kornealreflex) wurde über einen abdominalen Zugang das Zwerchfell eröffnet, der Herzsitus freipräpariert, nach Entfernen des Perikards das Herz durch Durchtrennen der großen Gefäße entnommen und zunächst in $4^{\circ} \mathrm{C}$ kalter $\mathrm{Ca}^{2+}$-freier Tyrode (2.11.4., Seite 35) ausgewaschen. Im Anschluss wurde das Herz nach der Methode von Langendorff (1895) durch die Aorta ascendens retrograd zuerst mit $\mathrm{Ca}^{2+}$-haltiger Tyrode (2.11.4., Seite 35) bis zum Wiedereinsetzen eines stabilen Herzschlags und folgend mit $\mathrm{Ca}^{2+}$-freier Tyrode für 7 10 min perfundiert. Zwischen Eintritt der Narkose und Wiedereinsetzen des Herzschlages in der Langendorff-Perfusion vergingen typischerweise $2 \mathrm{~min}$. So wurden ischämische Schädigungen der Kardiomyozyten vermindert.

Zum Verdau der Zell-Zell-Kontakte erfolgte eine 12-minütige Perfusion mit einer Enzymlösung (2.11.4., Seite 35), die Kollagenase Typ 2 (Biochrom, Berlin) und Protease Typ XIV (Sigma, Deisenhofen) enthielt. Bis zur weiteren Verarbeitung wurde das Herz im Anschluss mit albuminhaltiger Tyrode (Tyrode + BSA, 2.11.4., Seite 35) bei Raumtemperatur perfundiert.

Im Folgenden wurden die Ventrikel vom Vorhof abgetrennt, nacheinander in Isolationslösung \#3 und \#4 (2.11.4., Seite 35) gegeben, das erweichte Gewebe mit einer Schere zerkleinert und

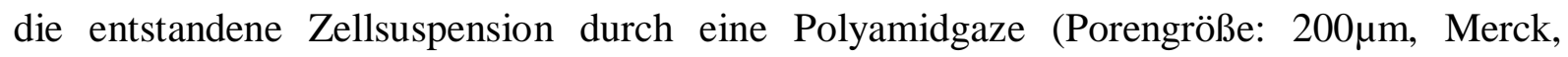


Darmstadt) gefiltert, um die noch enthaltenen Zellkonglomerate $\mathrm{zu}$ entfernen. In 5 aufeinander folgenden Isolationslösungen (Isolationslösungen \#5 bis \#9, 2.11.4., Seite 35) wurden die Zellen für jeweils 5-8 min sedimentiert, um gesunde Myozyten von geschädigten bzw. toten $\mathrm{zu}$ trennen. Der Überstand wurde bis auf $5 \mathrm{ml}$ nach abgelaufener Sedimentationszeit abgesaugt und das Pellet mit der nächsten Isolationslösung resuspendiert. Der Kalziumgehalt der Lösungen wurde dabei langsam gesteigert $(0,05,0,125,0,25,0,5$ und $1 \mathrm{mM} \mathrm{CaCl}_{2}$ ), um toxische Effekte des $\mathrm{Ca}^{2+}$ auf die Myozyten zu vermeiden. Für einen letzten Sedimentationsschritt wurden die Zellen in Albuminmedium (2.11.4., Seite 35) überführt und der Überstand nach abgeschlossener Sedimentation bis auf $5 \mathrm{ml}$ abgesaugt und nochmals durch frisches Albuminmedium ersetzt. $40 \mu 1$ der Zellsuspension wurde mit $40 \mu 1$ TrypanBlau-Lösung (2.11.4., Seite 35) versetzt und der Anteil stäbchenförmiger, nicht gefärbter Zellen (vital) durch eine Zählung in einer Neubauerkammer bestimmt.

\subsection{Transfektion}

\subsubsection{Zellkulturen zur RNA- und Proteingewinnung}

Die Effizienz der virusinduzierten Genexpression wurde auf RNA- und Proteinebene in RT-PCR bzw. Western Blot kontrolliert. Für die dazu benötigten Zellkulturen wurden Kulturschalen mit einem Durchmesser von $100 \mathrm{~mm}$ (Sarstedt, Nümbrecht) eine Stunde vor Gebrauch mit 3 ml Lamininlösung (2.11.5., Seite 36) beschichtet, um ein Anhaften der Zellen an den Boden zu gewährleisten. Nach einer Inkubationszeit von 45 Minuten wurde die Lösung wieder entfernt.

Je nach Isolationsausbeute wurden $5 \times 10^{5}$ oder 1 x $10^{6}$ der frisch isolierten Herzmuskelzellen in $5 \mathrm{ml}$ Medium (2.11.4., Seite 35), bzw. $10 \mathrm{ml}$ bei $1 \times 10^{6}$ Zellen, überführt. Anschließend wurden die Zellen getrennt mit aufsteigenden Viruskonzentrationen infiziert, so dass man eine virusfreie Zellkultur sowie je eine Kultur mit einer multiplicity of infection (MOI) von 1, 10, 100 und 1000 erhielt. MOI bezeichnet dabei die Anzahl der Viren pro Myozyt. Verwendet wurde ein Typ 5 Adenovirus mit dem inserierten FKBP12.6 ${ }^{\mathrm{G} 89 \mathrm{PV} 90 \mathrm{~K}}-\mathrm{Gen}$ (AdFKBP12.6 ${ }^{\mathrm{G} 89 \mathrm{PV} 90 \mathrm{~K}}$, institutseigene Herstellung). Nach Infektion wurden die einzelnen Zellkulturen in den laminierten Schalen ausplattiert und für 3 Stunden bei $37^{\circ} \mathrm{C}$ und $5 \% \mathrm{CO}_{2}$ inkubiert.

Anschließend wurde das Kulturmedium mit Viruspartikeln und nicht angehefteten Myozyten abgesaugt, die Zellen mit 1 x $10 \mathrm{ml}$ Medium gewaschen und anschließend erneut mit $10 \mathrm{ml}$ (bzw. $15 \mathrm{ml}$ ) Medium überschichtet. Die Zellkulturen verblieben weitere 48 Stunden unter 
Inkubationsbedingungen. Dann wurde wiederum das Medium entfernt, die Zellen in je $5 \mathrm{ml}$ PBS-Puffer (Invitrogen, Karlsruhe) aufgenommen und bei $1500 \mathrm{U} / \mathrm{min}$ und $4^{\circ} \mathrm{C}$ für $5 \mathrm{~min}$ zentrifugiert. Der Überstand wurde entfernt, das Zellpellet in flüssigem Stickstoff schockgefroren und bis zur weiteren Verwendung in RT-PCR und Western Blot bei $-80^{\circ} \mathrm{C}$ aufbewahrt.

\subsubsection{Zellkulturen für den B-Galaktosidase-Assay}

Zur direkten Messung der Transfektionseffizienz wurden hier je 5 x $10^{4}$ isolierte Zellen, enthalten in $1 \mathrm{ml}$ Medium, auf Kulturschalen mit einem Durchmesser von $35 \mathrm{~mm}$ (Sarstedt, Nümbrecht) ausplattiert. Die Schalen wurden zuvor mit je $1 \mathrm{ml}$ Lamininlösung präpariert und für 45 Minuten inkubiert.

Es wurde eine Transfektionsreihe mit MOI 0, 0,1, 1, 10 und 100 erstellt. Verwendet wurde das Virus Ad-LacZ, das für ß-Galaktosidase (B-Gal) kodiert, welche enzymatisch eine Farbreaktion in transfizierten Zellen katalysiert und so dem Nachweis einer adenoviralen Genübertragung dient. Die Zellen wurden wie in 2.6.1. beschrieben kultiviert und im Anschluss direkt dem B-Galaktosidase-Assay (siehe 2.7.) zugeführt.

\subsubsection{Zellkulturen zur Kontraktionsmessung}

Isolierte Zellen wurden wie unter 2.6.2. beschrieben ausplattiert und in zwei Gruppen geteilt. Dabei wurde eine Gruppe mit Ad- FKBP12.6 $6^{\mathrm{G} 89 \mathrm{PV} 90 \mathrm{~K}}$ und eine Kontrollgruppe mit Ad-LacZ infiziert, beide mit identischer MOI. In Folge wurde die Gruppenanordnung von einer nicht an den Experimenten beteiligten Person kodiert, um eine verblindete Untersuchung zu gewährleisten. Die Kultivierung erfolgte wie in 2.6.1. beschrieben. 48 Stunden nach Infektion wurden die Kontraktionsmessungen durchgeführt (siehe 2.10., Seite 32).

\subsection{B-Galaktosidase-Assay}

Um die optimale Viruszahl pro Kardiomyozyt zu ermitteln, wurde die Transfektionseffizienz anhand eines B-Galaktosidase-exprimierenden Adenovirus (Ad-LacZ) ermittelt. Die durch Ad-LacZ exprimierte ß-Galaktosidase wurde durch eine konventionelle ß-Gal-Färbung nachgewiesen. Die Bestimmung der optimalen Virusanzahl pro Kardiomyozyt dient der Gewährleistung einer möglichst hohen Transfektionsrate bei gleichzeitiger Vermeidung einer übermäßigen Virusexposition. Dies ist entscheidend für die folgenden Versuche mit für FKBP kodierenden Adenoviren, da dort einzelne Zellen mit unzureichender oder fehlender Transfektion die erwarteten Effekte der FKBP-Expression vermindern würden. 
Dazu wurden die unter 2.6.2. beschriebenen Zellkulturen nach Absaugen des Mediums zuerst durch Zugabe von je $1 \mathrm{ml}$ PBS (Invitrogen, Karlsruhe) mit 1\% Glutaraldehyd für 15 min bei $37^{\circ} \mathrm{C}$ fixiert. Die Fixierlösung wurde von den Schalen entfernt, die Zellen mit je $2 \mathrm{ml}$ PBS gewaschen, im Anschluss mit $1 \mathrm{ml} \mathrm{B-Gal-Färbelösung} \mathrm{(2.11.6.,} \mathrm{Seite} \mathrm{36)} \mathrm{überdeckt} \mathrm{und}$ wiederum für eine halbe Stunde bei $37^{\circ} \mathrm{C}$ belassen. Die Farbentwicklung wurde unter dem Mikroskop kontrolliert und die Reaktion bei ausreichender Intensität durch Entfernung der Färbelösung und Waschen mit $2 \mathrm{ml}$ PBS gestoppt. Die Myozyten wurden bei 100facher Vergrößerung unter dem Mikroskop dargestellt, und für je ein Sichtfeld pro Schale wurden blau gefärbte und farblose Zellen gezählt.

\subsection{Reverse-Transkriptase - Polymerase-Kettenreaktion (RT-PCR)}

\subsubsection{RNA-Isolation}

Zur Kontrolle der Effizienz des adenoviralen Gentransfers auf RNA-Ebene wurde zuerst RNA aus transfizierten Kardiomyozyten isoliert. Dazu wurde das RNeasy Mini Kit (Qiagen, Hilden) sowie Qiashredder Columns verwendet und nach dem Protokoll für die Isolation von Gesamt-RNA aus tierischen Einzelzellen verfahren. Es wurden die mitgelieferten Puffer verwendet (2.11.7., Seite 36).

Zunächst wurden die Zellpellets (2.6.1., Seite 26) in $350 \mu$ l einer Denaturierungslösung mit einem hochmolekularen, chaotropen Salz (RLT-Puffer, 2.11.7., Seite 36) lysiert, um vorhandene Proteine und RNasen $\mathrm{zu}$ denaturieren. Im Anschluss wurde das Lysat durch Zentrifugation in Schredderröhrchen (QIAshredder, Qiagen, Hilden) homogenisiert. Nach Zugabe von jeweils $350 \mu 1$ 70\% Ethanol wurde das Lysat durch eine Silikagelmembran filtriert (MiniSpinColumns, Qiagen, Hilden), die nach dem Prinzip von Anionenaustauschersäulen durch positiv geladene Diethylaminoethinylgruppen auf der Oberfläche die negativ geladenen Phosphatgruppen der Nukleinsäuren (bei $\mathrm{pH}>2$ ) bindet. Nach Zentrifugation für $15 \mathrm{~s}$ bei $10000 \mathrm{U} / \mathrm{min}$ wurde die filtrierte Flüssigkeit verworfen. Durch Waschschritte mit Puffern abnehmender Ionenstärke wurden selektiv DNA-Anteile ausgelöst. Dazu wurden zuerst $700 \mu \mathrm{l}$ RW1-Puffer (Qiagen, Hilden) auf die MiniSpinColumn pipettiert und diese im Anschluss für $15 \mathrm{~s}$ bei $10000 \mathrm{U} / \mathrm{min}$ zentrufugiert. Nach Verwerfen des Eluats erfolgte ein weiterer Waschschritt mit $500 \mu$ RPE-Puffer (2.11.7., Seite 36) gefolgt von einer weiteren Zentrifuagtion für $15 \mathrm{~s}$ bei 10000U/min. Dieser Schritt wurde wiederholt und die Zentrifugation zum Trocknen der Membran für 2 min bei maximaler Geschwindigkeit durchgeführt. Im Anschluss wurde die auf der Membran gebundene RNA durch Zugabe von 
$50 \mu \mathrm{l}$ Wasser und Zentrifugation für $1 \mathrm{~min}$ bei maximaler Geschwindigkeit eluiert. Dieser Schritt wurde ohne Verwerfen der gesammelten Flüssigkeit des vorangegangenen Schrittes wiederholt. Um die im Eluat $(100 \mu \mathrm{l})$ enthaltene RNA von Verschmutzungen wie Proteinen $\mathrm{zu}$ reinigen und sie aufzukonzentrieren, wurden zum 0,1 (v/v) $3 \mathrm{M}$ Natriumacetat $\mathrm{pH}$ 4,0, 2,5 (v/v) 100\% Ethanol und $1 \mu \mathrm{l}$ Glycogen $(20 \mu \mathrm{g} / \mu \mathrm{l})$ zugegeben und der Ansatz über Nacht (circa 20 Stunden) bei $-20^{\circ} \mathrm{C}$ präzipitiert. Am nächsten Tag erfolgte die Zentrifugation bei $4^{\circ} \mathrm{C}$ und $15000 \mathrm{U} / \mathrm{min}$ für $30 \mathrm{~min}$. Der Überstand wurde restlos abpipettiert und das Pellet erneut mit $800 \mu \mathrm{l}$ Ethanol (80\%) resuspendiert. Nach einer weiteren Zentrifugation bei $4^{\circ} \mathrm{C}$ und $15000 \mathrm{U} / \mathrm{min}$ für 15 min wurde der Überstand verworfen und das RNA-Pellet nochmals wie beschrieben resuspendiert und zentrifugiert. Auch hier wurde der Überstand abpipettiert und das Pellet in $12 \mu 1$ RNase-freiem Wasser aufgenommen. $2 \mu 1$ dieser Lösung wurden 1:100 in Wasser verdünnt und die Konzentration bei $260 \mathrm{~nm}$ photometrisch bestimmt.

\subsubsection{Synthese komplementärer DNA (cDNA)}

Für eine Amplifikation des FKBP12.6 $6^{\mathrm{G} 89 \mathrm{PV} 90 \mathrm{~K}}-$ Gens muss die RNA zuerst in EinzelstrangcDNA überführt werden. Dazu wurde das SuperScript ${ }^{\circledR}$ First-Strand System (Invitrogen, Karlsruhe) verwendet und nach den Angaben des Herstellers verfahren.

Zunächst wurde die RNA-Lösung (siehe 2.8.1.) für 15 min bei Raumtemperatur mit DNase I verdaut (1 Unit/pg RNA), damit DNA-Kontaminationen der isolierten RNA durch genomische oder Virus-DNA und dementsprechend falsch positive PCR-Signale ausgeschlossen werden konnten. Um sicherzustellen, dass in der PCR gleiche cDNA-Mengen zum Einsatz kommen, wurden die einzelnen RNA-Konzentrationen vor dem Verdau durch Verdünnung auf die niedrigste der entsprechenden Isolation angeglichen. Die DNase I wurde anschließend hitzeinaktiviert.

Im Weiteren wurden jeweils $9 \mu \mathrm{l}$ der aufgereinigten RNA ( 240 ng) mit $3 \mu$ l Random Hexamers (Hexamer-Nukleotide zufälliger Basenzusammensetzung) und $1 \mu \mathrm{dNTP}-\mathrm{Mix}$ sowie $10 \mu \mathrm{l} \mathrm{H}_{2} \mathrm{O}$ vermischt und bei $65^{\circ} \mathrm{C}$ für $5 \mathrm{~min}$ inkubiert. Danach wurden die Reaktionsansätze für $1 \mathrm{~min}$ auf Eis gekühlt. $\mathrm{Zu}$ jedem Ansatz wurden folgend $9 \mu 1$ Reaktionsmix (2.11.7, Seite 36) pipettiert und für 2 min bei $25^{\circ} \mathrm{C}$ inkubiert. Durch Zugabe von je $1 \mu$ l einer modifizierten MMLV-Reverse-Transkriptase (RT), die durch eine Punktmutation keine intrinsische RNase H-Aktivität besitzt (SuperScript II ${ }^{\mathrm{TM}}-\mathrm{RT}$, Invitrogen, Karlsruhe) wurde die Umschreibung der RNA in cDNA nach einem Inkubationsschritt bei $25^{\circ} \mathrm{C}$ für 10 min durch Erwärmung auf $42^{\circ} \mathrm{C}$ gestartet und die Reaktion nach 50 min durch Erhitzen auf $70{ }^{\circ} \mathrm{C}$ für 15 min gestoppt. Im Anschluss erfolgte wiederum ein Abkühlen auf 
Eis.Der Verdau der noch enthaltenen RNA erfolgte durch jeweils $1 \mu$ RNase H und Inkubation bei $37^{\circ} \mathrm{C}$ für $20 \mathrm{~min}$.

Als Negativkontrollen wurden Ansätze ohne Reverse-Transkriptase (-RT) und ohne RNA $\left(\mathrm{H}_{2} \mathrm{O}\right)$ mitgeführt.

\subsubsection{PCR}

Zur PCR-Amplifikation (Saiki et al. 1985) von FKBP12.6 ${ }^{\mathrm{G} 89 \mathrm{PV} 90 \mathrm{~K}}$ wurden als Primer Teile der humanen FKBP12.6-Sequenz eingesetzt, die den kompletten Leserahmen des 662 bp großen, transfizierten Gens einschlossen. Als Referenzgen wurde Calsequestrin (353 bp), spezifisch für Calsequestrin in Kaninchen, amplifiziert. Die Primer sind in Tabelle 3 aufgeführt.

\begin{tabular}{|l|l|l|}
\hline & Vorwärtsprimer & Rückwärtsprimer \\
\hline FKBP12.6 G89PV90K & 5'cagcagcagggatcccccagaggc3 3 $^{\prime}$ & 5'ttgtgcgaacaagggatccgtgttctgtcatcagg3' \\
\hline Calsequestrin & 5'agcccactcccatccccaaca3' & 5'gtcagcgtccgtcacattcacca3' \\
\hline
\end{tabular}

Tab. 3: In der PCR verwendete Vorwärts- und Rückwärtsprimer

Zur Amplifikation wurde ein Reaktionsgemisch, bestehend aus $4 \mu 1$ 10X PCR-Puffer (2.11.7., Seite 36), $3 \mu \mathrm{l} \mathrm{MgCl}_{2}, 1 \mu \mathrm{l}$ dNTP-Mix (je $25 \mathrm{mM}$ dATP, dGTP, dTTP, dCTP, Bioline Luckenwalde), $2 \mu$ l Vorwärtsprimer, $2 \mu$ l Rückwärtsprimer, $3 \mu$ cDNA (siehe 2.8.2.), 0,5 $\mu 1$ Taq-Polymerase (AmpliTaqGold ${ }^{\mathrm{TM}}$, Roche, Grenzach-Wyhlen) sowie 24,5 $\mu \mathrm{l} \mathrm{H}_{2} \mathrm{O}$, hergestellt.

Außer den einzelnen Probenansätzen (MOI 0, 1, 10, 100, 1000) wurden die Kontrollen der cDNA-Synthese (-RT, $\left.\mathrm{H}_{2} \mathrm{O}\right)$ und zusätzlich eine Positivkontrolle, bestehend aus hochverdünnter humaner FKBP12.6-cDNA, mitgeführt.

Das Reaktionsgemisch wurde in einem Thermocycler (MJ-Research PTC-200, BioRad, München) nach dem folgenden Protokoll behandelt.

Zunächst wurde die cDNA bei $95^{\circ} \mathrm{C}$ für 1 min inkubiert. Im Anschluss erfolgten 35 Zyklen, die jeweils aus drei Schritten bestanden: Denaturierung bei $94^{\circ} \mathrm{C}$ für $45 \mathrm{~s}$, Hybridisation bei $56^{\circ} \mathrm{C}$ für $45 \mathrm{~s}$ und abschließend die Synthese bei $72^{\circ} \mathrm{C}$ für ebenfalls $45 \mathrm{~s}$.

Nach dem letzten Zyklus wurde eine zusätzliche Synthesephase von 10 min bei $72^{\circ} \mathrm{C}$ durchgeführt, um bereits bestehende noch unvollständige DNA-Stränge zur vollständigen Länge zu synthetisieren. Nach Abschluss der PCR wurden die Proben zur weiteren Verarbeitung bei $4^{\circ} \mathrm{C}$ gelagert. 


\subsubsection{Gelelektrophorese}

In $80 \mathrm{ml}$ 0,5X TBE (2.11.7., Seite 36) wurden 2\% Agarose (Seakem, Biozym, Hessisch Oldendorf) gelöst und die Mischung aufgekocht. Zusätzlich wurden 1,5 $\mu$ l Ethidiumbromid (10 mg/ml) hinzugefügt, welches Doppelstrang-DNA interkaliert und sie so unter UVBeleuchtung sichtbar macht. Die Agarose wurde in eine entsprechende Form gegossen und nach abgeschlossener Polymerisation direkt in eine mit 0,5X TBE-Puffer gefüllte Elektrophoresekammer überführt. Nach Beendigung der PCR-Reaktion wurden $17 \mu \mathrm{l}$ jedes Ansatzes mit $3 \mu$ l Bromphenolblaupuffer (2.11.7., Seite 36) versetzt und für eine Stunde bei $250 \mathrm{~mA}$ elektrophoretisch aufgetrennt. Zur späteren Größenbestimmung der Banden wurde ein Proteinstandard (Gibco, Karlsruhe) mitgeführt. Danach wurde das Gel unter UVDurchleuchtung kontrolliert und im Photoimager digitalisiert.

\subsection{SDS-PAGE und Western Immunoblot}

\subsubsection{Lysatherstellung und Proteinkonzentrationsbestimmung}

Die Expression des adenoviral eingebrachten Gens für FKBP12.6 ${ }^{\mathrm{G} 89 \mathrm{PV} 90 \mathrm{~K}}$ wurde auch auf Proteinebene durch SDS-PAGE- und Western-Blot-Analyse nachgewiesen. Dazu wurden zuerst die unter 2.6.1. (Seite 26) beschriebenen Pellets aus Kardiomyozyten lysiert, indem sie dreimal aufgetaut und anschließend in flüssigem Stickstoff wieder eingefroren wurden. Die Zellen wurden in $500 \mu$ l Lysepuffer (2.11.8., Seite 37) resuspendiert, für $30 \mathrm{~min}$ auf Eis gelagert und durch mehrmaliges Ziehen der Lösungen durch eine 26 G-Kanüle homogenisiert. Die Suspensionen wurden bei $4^{\circ} \mathrm{C}$ und $15000 \mathrm{U} / \mathrm{min}$ für $15 \mathrm{~min}$ zentrifugiert und der Überstand in der Gelelektrophorese verwendet.

Die Proteinkonzentrationen der Lysate wurde wie unter 2.2.5. (Seite 22) beschrieben bestimmt.

\subsubsection{SDS-PAGE}

Zur elektrophoretischen Auftrennung der Proteinlysate aus adenoviral transfizierten Herzmuskelzellen wurden die unter 2.2.4. (Seite 21) beschriebenen hochauflösenden Gele verwendet. Pro Probe wurden $25 \mu$ g Protein gelöst in Lysepuffer mit $20 \mu 1$ modifiziertem Proben-Puffer (2.11.8., Seite 37) versetzt und wie unter 2.2.4. (Seite 21) beschrieben behandelt. Als Größenmarker dienten $20 \mu$ Proteinstandard (Precision Protein Standards, BioRad). 


\subsubsection{Transfer auf Nitrozellulose}

Nach der Methode von Towbin et al. (1979), wurden die nach Größe aufgetrennten Proteine vom Polyacrylamidgel durch Elektrophorese auf eine Nitrozellulosemembran transferiert. Dazu wurden nach Abschluss der SDS-PAGE-Analyse Trenn- und Sammelgel voneinander getrennt und letzteres verworfen. Das Trenngel wurde auf eine Nitrozellulosemembran (Schleicher \& Schüll, Dassel) gelegt. Zur besseren Fixierung und Kompression wurde beides mit je einer Lage Filterpapier und Schwamm umgeben. Alle Materialien wurden vor Verwendung in Transferpuffer (2.11.8., Seite 37) getränkt. Im Anschluss erfolgte das Einspannen in eine Transfervorrichtung, die in eine Elektrophoresekammer eingehängt wurde. Nach Auffüllen der Elektrophoresekammer mit Transferpuffer erfolgte der Transfer mit $500 \mathrm{~mA}$ für 2 Stunden. Dabei wurde die Kammer in einem Eisbad mit zusätzlichen Kühlakkus platziert und die Akkus nach einer Stunde erneuert.

\subsubsection{Immundetektion}

Die der Nitrozellulosemembran anhaftenden Proteine können durch spezifische Antikörper detektiert werden. Um freie Bindungstellen zu sättigen, wurde die Membran direkt nach dem Transfer für 16 Stunden bei $4^{\circ} \mathrm{C}$ in $5 \%$ Milchpuffer (2.11.8., Seite 37) inkubiert, danach 3 x 5 min in TweenTBS (2.11.8., Seite 37) gewaschen und anschließend für eine Stunde bei

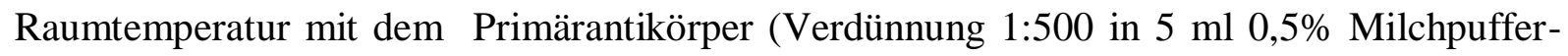
TTBS, 2.11.8., Seite 37) inkubiert, der gegen die letzten C-terminalen AS gerichtet ist (SA 168, Santa Cruz, USA). Danach erfolgten wiederum 3 Waschschritte von jeweils 5 min mit TweenTBS und die Inkubation mit Sekundärantikörper (anti-rabbit IgG, Amersham, Freiburg) in einer Verdünnung von 1:10000 in 0,5\%-Milchpuffer-TTBS für eine weitere Stunde bei Raumtemperatur. Anschließend wurde die Membran erneut 3 x 10 min in Tween TBS gewaschen, um unspezifisch bindende Antikörper abzuwaschen.

Im Anschluss wurde die Membran für 5 min SuperSignal ${ }^{\mathrm{TM}}$ Chemilumineszenz-Substrat (Pierce, Bonn) behandelt und folgend für 5 bis 30 min einem Röntgenfilm (Fuji Medical XRay, Fuji Düsseldorf) exponiert und der Film nach Anleitung des Herstellers entwickelt.

\subsection{Myozytenkontraktionsmessungen}

\subsubsection{Versuchsaufbau und Messbedingungen}

Um den Einfluss des exprimierten FKBP12.6 ${ }^{\text {G89PV90K }}$ auf das Kontraktionsverhalten der Herzmuskelzelle im Vergleich zu ß-Gal-transfizierten Myozyten zu untersuchen, wurde das 


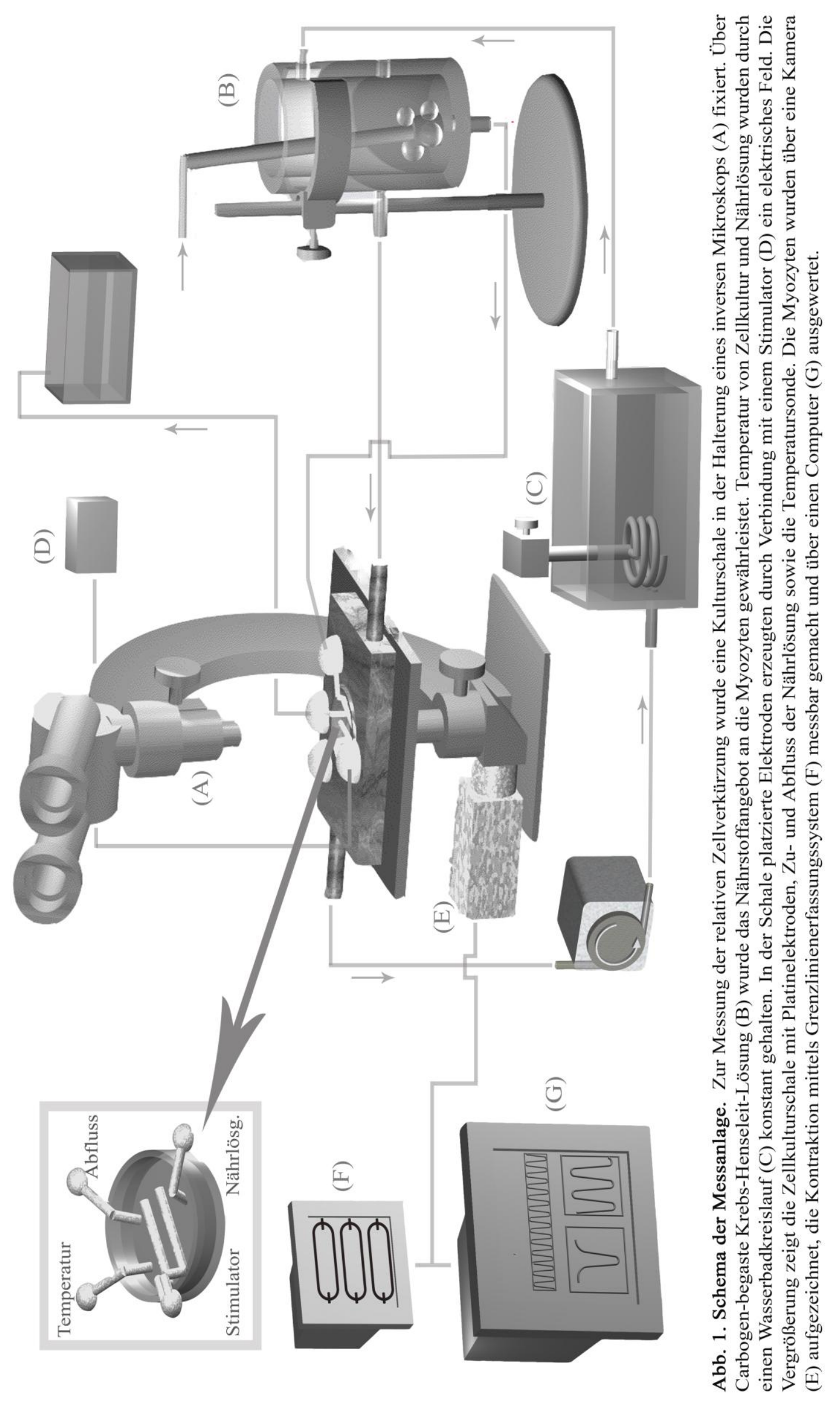


Medium der transfizierten Zellkulturen (siehe 2.6.3., Seite 27) entfernt und die Schale im Halterungssystem eines inversen Mikroskops fixiert (siehe Abb. 1). Die Kulturschale wurde mit gleichbleibend warmem Wasser umspült. Krebs-Henseleit-Lösung (2.11.9., Seite 37) wurde mit Carbogen $\left(95 \% \mathrm{O}_{2}, 5 \% \mathrm{CO}_{2}\right)$ begast und über eine Rollerpumpe in das Schälchen geleitet. Durch eine an das gleiche Pumpsystem angeschlossene Absaugkanüle wurde ein konstanter $\mathrm{Zu}$ - und Abfluss in der Schale gewährleistet sowie Temperatur $\left(37^{\circ} \mathrm{C}\right)$, Nährstoffangebot und $\mathrm{pH}(7,3)$ für die Myozyten konstant gehalten. Eine auf dem Boden der Schale aufgebrachte bipolare Elektrode erzeugte ein elektrisches Feld, in dem die Myozyten mit einer Frequenz von $1 \mathrm{~Hz}$ stimuliert wurden. Über ein Videosystem wurde das durch das Mikroskop sichtbare Feld der Schale in einer 40-fachen Vergrößerung auf einen Monitor übertragen. Die Enden eines eingestellten Myozyten wurden über ein Grenzlinienerfassungssystem, das den Kontraktionsbewegungen des Myozyten folgt, registriert und so die Zelllänge mit einem angeschlossenen Computerprogramm (hausinternes Programm auf der Basis von LabView, National Instruments, Austin/Texas, USA) messbar gemacht.

Pro Schale wurden drei auf gesamter Länge anhaftende Myozyten zufällig ausgesucht, mit einer Frequenz von $1 \mathrm{~Hz}$ stimuliert und gewartet, bis eine konstante Kraftentwicklung zu beobachten war. Protokolliert wurden die Parameter absolute und relative Verkürzung zur diastolischen Zelllänge, die Zelllänge in Ruhe und in Maximalkontraktion, Kontraktions- und Relaxationsgeschwindigkeit sowie die Zeit bis zur maximalen Kontraktion. Untersucht wurden Zellgruppen mit Viruskonzentrationen von MOI 10 und MOI 50, jeweils Ad-LacZ-

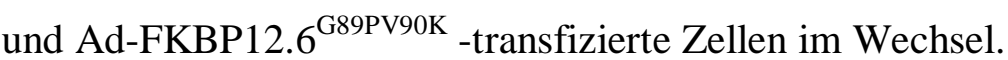

\subsubsection{Statistika}

Die Gruppenzuordnung wurde dekodiert und die gespeicherten Messwerte mit der Software SigmaStat $^{\mathrm{TM}}$ (Jandel Scientific, Linslade, Großbritannien) im Student's t-Test für unpaarige Werte geprüft. Dabei wurde ein $p<0,05$ als statistisch signifikant betrachtet. Die graphische Darstellung erfolgte als Mittelwert \pm Standardfehler der Mittelwerte (SEM).

\subsection{Verwendete Lösungen und Substanzen}

\subsubsection{Herstellung rekombinanter Proteine}

LB-Amp-Kultur

$5 \mathrm{~g}$ Hefeextrakt, $10 \mathrm{~g} \mathrm{NaCl}, 10 \mathrm{~g}$ Bacto Trypton, $100 \mu \mathrm{g} / \mathrm{ml}$

Ampicillin, mit $\mathrm{ddH}_{2} \mathrm{O}$ auf $500 \mathrm{ml}$ auffüllen 
Puffer W

Puffer E

Puffer R

4X TRIS/SDS-Puffer $p H 8,8$

4X TRIS/SSDS-Puffer $p H 6,8$

Proben-Puffer

5X Laufpuffer

1X Laufpuffer

Entfärbelösung

\subsubsection{Calcineurinaktivitäts-Assay}

Calcineurin-Assay-Puffer $100 \mathrm{mM}$ Tris pH 7,5, $200 \mathrm{mM} \mathrm{NaCl}, 12 \mathrm{mM} \mathrm{MgCl} 2,1 \mathrm{mM}$ DTT, 0,05\% NP-40, $1 \mathrm{mM} \mathrm{CaCl}_{2}$, $500 \mathrm{nM}$ Calmodulin

\subsubsection{Rotamase-Assay}

Rotamase-Assay-Puffer

\subsubsection{Myozytenisolation}

10X Tyrode

IX Tyrode mit Kalzium

1X Tyrode ohne Kalzium

$100 \times$ Pen/Strep

100mM Tris/HCl, 1mM EDTA, auf $\mathrm{pH} 8,0$ titrieren

Puffer W mit 2,5 mM Desthiobiotin

Puffer $\mathrm{W}$ mit $1 \mathrm{mM}$ HABA

45,5 g Tris Base, $1 \mathrm{~g} \mathrm{SDS}$, mit $\mathrm{ddH}_{2} \mathrm{O}$ auf $250 \mathrm{ml}$ auffüllen,

Titration mit $\mathrm{HCl}$ auf $\mathrm{pH} \mathrm{8,8}$

Titration mit $\mathrm{HCl}$ auf $\mathrm{pH} \mathrm{6,8}$

$10 \mathrm{mM}$ Tris/HCl, 1 mM EDTA, $1 \%$ SDS, $12 \%$ Glycerol, 0,01\% Bromphenolblau

Titration mit $\mathrm{HCl}$ auf $\mathrm{pH} 6,8$

30,2 g Tris Base, 10 g SDS, 144 g Glycin, mit ddH ${ }_{2} \mathrm{O}$ auf 2 Liter auffüllen, Titration mit $\mathrm{HCl}$ auf $\mathrm{pH} 8,3$

200ml 5X SDS-PAGE-Puffer, mit $\mathrm{ddH}_{2} \mathrm{O}$ auf 1 Liter auffüllen

$50 \%$ Ethanol, $10 \%$ Essigsäure in $\mathrm{ddH}_{2} \mathrm{O}$

$35 \mathrm{mM}$ HEPES, $10 \mathrm{mM}$ DTT, 0,015\% TritonX

Titration mit $\mathrm{HCl}$ auf $\mathrm{pH} 7,9$

80,06 g NaCl, 4,03 g KCl, 2,96 g $\mathrm{MgSO}_{4} \times 7 \mathrm{H}_{2} \mathrm{O}, 4,3 \mathrm{~g}$ $\mathrm{Na}_{2} \mathrm{HPO}_{4} \mathrm{x} 12 \mathrm{H}_{2} \mathrm{O}$, 47,66 g HEPES, mit $\mathrm{ddH}_{2} \mathrm{O}$ auf 1 Liter auffuillen, Titration mit $\mathrm{NaOH}$ auf $\mathrm{pH} 7,54$

100ml 10X Tyrode, $1 \mathrm{ml} \mathrm{CaCl} 2$ (1 mol/l), 2,74 g Glukose, mit $\mathrm{ddH}_{2} \mathrm{O}$ auf 1 Liter auffüllen

$200 \mathrm{ml} \mathrm{10X}$ Tyrode, 5,4 g Glukose, $20 \mathrm{ml}$ 100X Pen/Strep-

Lösung, mit $\mathrm{ddH}_{2} \mathrm{O}$ auf 2 Liter auffüllen

$10 \mathrm{ml}$ Penicillin (10000 U/ml), $10 \mathrm{ml}$ Streptomycin

(10 mg/ml), mit $0,9 \% \mathrm{NaCl}$ auf 1 Liter auffüllen 
Enzymlösung

Tyrode $+B S A$

Isolationslösung \#3

Isolationslösung \#4 und \#5

Isolationslösung \#6

Isolationslösung \#7

Isolationslösung \#8

Isolationslösung \#9

Medium

Albuminmedium

Trypan-Blau-Lösung

\subsubsection{Transfektion}

Lamininlösung

Laminin $(1 \mathrm{mg} / \mathrm{ml})$

Medium

Medium

80 ml 1X Tyrode ohne Kalzium, 600 mg Taurin, 94 mg DLGlutaminsäure, 31 mg DL-Carnitine, 103,3 mg Kollagenase II (357 U/mg), 2,1 mg Protease XIV, $2 \mu \mathrm{CaCl}_{2}(1 \mathrm{~mol} / \mathrm{l})$,

Titration mit $\mathrm{NaOH}$ auf $\mathrm{pH} 7,54$

$300 \mathrm{ml} 1 \mathrm{X}$ Tyrode ohne Kalzium, $15 \mu \mathrm{l} \mathrm{CaCl}_{2}(1 \mathrm{~mol} / \mathrm{l}), 6 \mathrm{~g}$ Albumin Fraktion V, 607 mg BDM,

Titration mit $\mathrm{NaOH}$ auf $\mathrm{pH} 7,54$

$40 \mathrm{ml} 1 \mathrm{X}$ Tyrode ohne Kalzium, $2 \mu \mathrm{CaCl}_{2}(1 \mathrm{~mol} / \mathrm{l}), 81 \mathrm{mg}$ $\mathrm{BDM}$

$40 \mathrm{ml} 1 \mathrm{X}$ Tyrode ohne Kalzium, $2 \mu \mathrm{CaCl}_{2}(1 \mathrm{~mol} / \mathrm{l})$

$25 \mathrm{ml} 1 \mathrm{X}$ Tyrode ohne Kalzium, 3,12 $\mu \mathrm{l} \mathrm{CaCl}_{2}(1 \mathrm{~mol} / \mathrm{l})$

$25 \mathrm{ml} 1 \mathrm{X}$ Tyrode ohne Kalzium, 6,25 $\mu \mathrm{l} \mathrm{CaCl}_{2}(1 \mathrm{~mol} / \mathrm{l})$

$25 \mathrm{ml} 1 \mathrm{X}$ Tyrode ohne Kalzium, 12,5 $\mu \mathrm{CaCl}_{2}(1 \mathrm{~mol} / \mathrm{l})$

$25 \mathrm{ml} 1 \mathrm{X}$ Tyrode ohne Kalzium, $25 \mu \mathrm{CaCl}_{2}(1 \mathrm{~mol} / \mathrm{l})$

Alle Isolationslösungen wurden steril gefiltert.

500 ml M199 Medium (Sigma, \#M7528), 312,5 mg Taurin, 500 mg L-Carnitin, 327, 5 mg Kreatin, 5 ml 100X Pen/StrepLösung, 5 ml 100X L-Glutamin $500 \mathrm{ml}$ Medium, $30 \mathrm{~g}$ Albumin Fraktion V $100 \mu 1$ 0,5\% Trypan-Blau, $900 \mu 1$ PBS

je $30 \mathrm{mmm}$ Kulturschale $10 \mu \mathrm{l}$

$1 \mathrm{ml}$

siehe 2.11.4.

\subsubsection{B-Galaktosidase-Assay}

ß-Gal-Färbelösung

$5 \mathrm{mM}$ Potassium Ferrocyanid, $5 \mathrm{mM}$ Potassium Ferricyanid,

1 mg/ml X-Gal (5-Bromo-4-chloro-3-indolyl-D-

galactopyranosidecrystal) in PBS (Invitrogen, Karlsruhe)

\subsubsection{Reverse-Transkriptase - Polymerase-Kettenreaktion (RT-PCR)}


RPE-Puffer

Reaktionsmix

10X PCR-Puffer

5X TBE-Puffer

0,5X TBE-Puffer

Bromphenolblaupuffer
1 Einheit RPE-Puffer (Qiagen, Hilden), 4 Einheiten Ethanol

$2 \mu l$ 10X RT-Puffer, $4 \mu \mathrm{l} 25$ mM MgCl $2,2 \mu \mathrm{l}$ 0,1 M DTT,

$1 \mu 1$ RnaseOUT Recombinant Ribonuclease Inhibitor $500 \mathrm{mM}$ Tris/ $\mathrm{HCl}\left(\mathrm{pH} \mathrm{9,1),} 140 \mathrm{mM}\left(\mathrm{NH}_{4}\right)_{2} \mathrm{SO}_{4}\right.$ (Roche, Grenzach-Wyhlen)

27,26 g Tris, 13,99 g Borat, 1,86 g EDTA, mit $\mathrm{ddH}_{2} \mathrm{O}$ auf 1 Liter auffüllen

$100 \mathrm{ml}$ 5X TBE-Puffer, mit $\mathrm{ddH}_{2} \mathrm{O}$ auf 1 Liter auffüllen $20 \mathrm{mg}$ Bromphenolblau, $5 \mathrm{ml}$ Glycerol, $1 \mathrm{ml}$ 5X TBE-Puffer, mit $\mathrm{ddH}_{2} \mathrm{O}$ auf 10 Milliliter

\subsubsection{SDS-PAGE und Western Immunoblot}

Lyse-Puffer (Basis)

Lyse-Puffer

Modifizierter Proben-Puffer

5X Transferpuffer

IX Transferpuffer

$10 X T B S$

TweenTBS(TTBS)

5\%-Milchpuffer
211,1 mg Tris/HCl, 818,1 g NaCl, $1 \mathrm{ml}$ Triton X $10 \%$, mit $\mathrm{ddH}_{2} \mathrm{O}$ auffüllen, Titration mit $\mathrm{HCl}$ auf $\mathrm{pH} 7,4$

5ml Lyse-Puffer (Basis), $10 \mu$ PMSF (500 M in DMSO), 10

$\mu 1$ Leupeptin $(5 \mathrm{mg} / \mathrm{ml}), 5 \mu 1$ Trypsininhibitor, $5 \mu$ Aprotinin $(1 \mathrm{mg} / \mathrm{ml})$

Proben-Puffer (siehe 2.11.1.) mit 500 mM DTT

39,4 g Tris Base, $144 \mathrm{~g}$ Glycin, mit $\mathrm{ddH}_{2} \mathrm{O}$ auffüllen $200 \mathrm{ml}$ 5X Transferpuffer, $200 \mathrm{ml}$ Methanol, mit $\mathrm{ddH}_{2} \mathrm{O}$ auf 1 Liter auffüllen 48,4 g Tris Base, 58,48 g NaCl, mit $\mathrm{ddH}_{2} \mathrm{O}$ auf 2 Liter auffüllen, Titration mit $\mathrm{HCl}$ auf $\mathrm{pH} 7,4$ $500 \mathrm{ml}$ 10X TBS, $5 \mathrm{ml}$ Tween 20, mit $\mathrm{ddH}_{2} \mathrm{O}$ auf 5 Liter auffüllen

2,5 g Trockenmilchpuffer, mit Tween-TBS auf $50 \mathrm{ml}$ auffüllen

0,5\%-Milchpuffer-TTBS-Puffer $5 \mathrm{ml} 5 \%$-Milchpuffer, mit TweenTBS auf $50 \mathrm{ml}$ auffüllen

\subsubsection{Myozytenkontraktionsmessungen}

10X Krebs-Henseleit-Lösung $\quad 67,8 \mathrm{~g} \mathrm{NaCl}, 3,73 \mathrm{~g} \mathrm{KCl}, 2,44 \mathrm{~g} \mathrm{MgCl}_{2} \mathrm{x} 6 \mathrm{H}_{2} \mathrm{O}, 1,7 \mathrm{~g} \mathrm{Na}_{2} \mathrm{SO}_{4}$, 2,76 $\mathrm{g} \mathrm{NaH}_{2} \mathrm{PO}_{4} \mathrm{x} \mathrm{H}_{2} \mathrm{O}$, mit $\mathrm{ddH}_{2} \mathrm{O}$ auf 1 Liter auffüllen

Krebs-Henseleit-Lösung $100 \mathrm{ml}$ 10X Krebs-Henseleit-Lösung, 1,8 g Glukose, 1,7 g $\mathrm{NaHCO}_{3}, 2 \mu \mathrm{l} 1 \mathrm{M} \mathrm{CaCl}_{2}$, mit ddH $\mathrm{H}_{2} \mathrm{O}$ auf 1 Liter auffüllen 


\section{ERGEBNISSE}

\subsection{DNA-Mutation zur Erzeugung einer Calcineurin-Bindungsdefizienz}

Aus den Arbeiten von Cameron et al. (1995) und Bandyopadhyay et al. (2000) geht hervor, dass Calcineurin über FKBP an den RyR2 bindet. Um die Auswirkungen der Phosphatase auf die RyR-FKBP12.6-Interaktion indirekt zu untersuchen, bestand ein Ziel dieser Arbeit darin, eine FKBP12.6-Isoform $\mathrm{zu}$ generieren, die nicht in der Lage ist, mit Calcineurin $\mathrm{zu}$ interagieren.

Aus Untersuchungen an FKBP12.0 ist bekannt, dass Punktmutationen an Position 89 und 90 des Proteins eine starke Calcineurinbindungsdefizienz verursachen. Dabei wurden an Position 89 die Aminosäuren Glycin gegen Prolin (G89P) und an Position 90 Isoleucin gegen Lysin getauscht (I90K). Im Vergleich zu dieser Mutante besitzt natives FKBP12.0 eine 500fach höhere Calcineurinbindungsaktivität (Yang et al. 1993).

Wildtyp

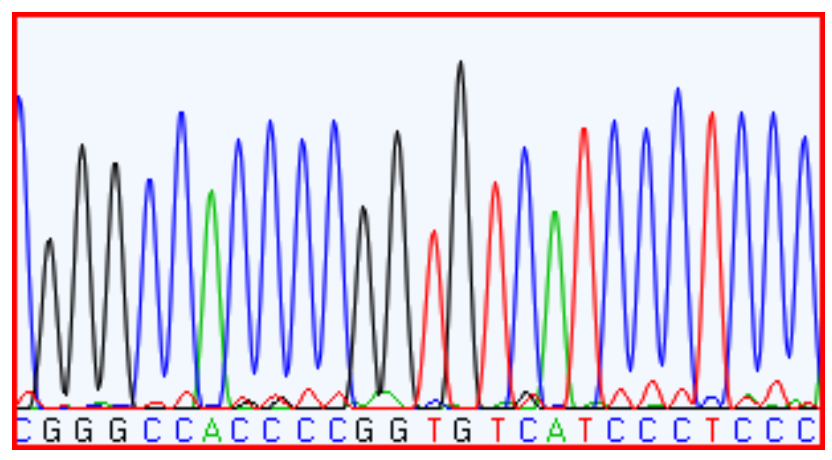

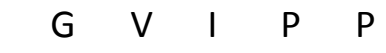

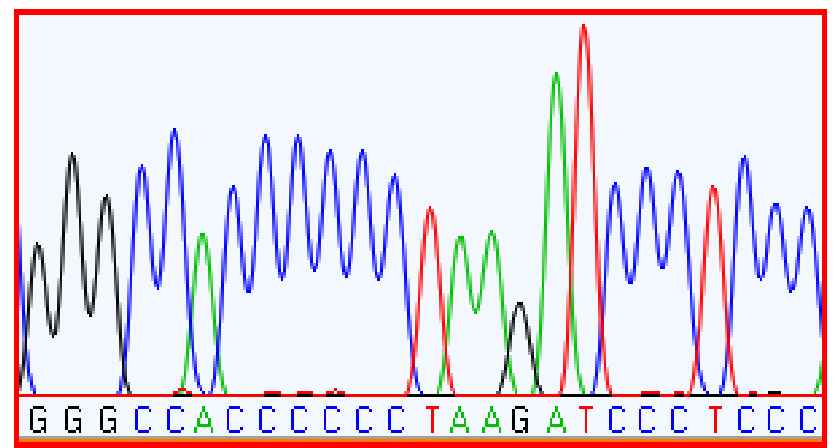

G
$\mathrm{H}$

\section{$\begin{array}{llll}K & \mathrm{I} & \mathrm{P} & \mathrm{P}\end{array}$}

8990
DNA Sequenzchromatogramm

DNA Basensequenz

Translation in Aminosäuresequenz

DNA Sequenzchromatogramm

DNA Basensequenz

Translation in Aminosäuresequenz Nr. Aminosäure ab Startcodon

Abb. 2. DNA-Sequenzchromatogramme. Original DNA-Sequenzchromatogramme für Wildtyp FKBP12.6 DNA (oben) und nach zielgerichteter Mutagenese (unten). Die DNASequenzierung weist die erfolgreiche Mutation zu FKBP12.6 ${ }^{\text {G89PV90K }}$ nach. 
Diese Erkenntnisse wurden in dieser Arbeit auf die Generierung der Calcineurinbindungsdefizienten FKBP12.6-Mutante übertragen. Es erfolgte ein analoger Aminosäureaustausch, wobei an Position 90 aufgrund einer natürlichen Aminosäuresequenzabweichung im FKBP12.6-Molekül Valin durch Lysin ersetzt wurde (V90K). Die Mutation wurde mittels zielgerichteter Mutagenese generiert. Eine DNASequenzierung (Seqlab,Göttingen) bestätigte zweifelsfrei die vollständige und alleinige Mutation an Position 89 und 90 des DNA-Konstruktes (Abb. 2). Somit wurde in dieser Arbeit erstmals eine Calcineurin-bindungsdefiziente FKBP12.6-Mutante erzeugt (FKBP12.6 $\left.6^{\mathrm{G} 89 \mathrm{PV} 90 \mathrm{~K}}\right)$. Die DNA wurde zur Erzeugung von rekombinantem FKBP12.6 ${ }^{\mathrm{G} 89 \mathrm{PV} 90 \mathrm{~K}}$ in E.coli und für die Herstellung rekombinanter Adenoviren zur Expression von FKBP12.6 $6^{\mathrm{G} 89 \mathrm{PV} 90 \mathrm{~K}}$ in Kardiomyozyten verwendet.

\title{
3.2. Rekombinante Herstellung von FKBP und Charakterisierung
}

\subsubsection{Proteinexpression}

Die Proteine FKBP12.0, 12.6 und $12.6^{\mathrm{G} 89 \mathrm{PV} 90 \mathrm{~K}}$ wurden rekombinant in E. coli exprimiert, um sie in vitro untersuchen zu können. Die Proteinexpression wurde dabei durch Zugabe von Anhydrotetrazyklin induziert. Nach einer Inkubationszeit von 3 Stunden wurde der Vorgang gestoppt, da zu diesem Zeitpunkt das exponentielle Wachstum der Bakterien sistierte und die höchste Ausbeute an rekombinantem Protein erreicht werden konnte (Abb. 3).

$\begin{array}{llllllll}\text { Zeit/Minuten } & 0 & 30 & 60 & 90 & 120 & 150 & 180 \\ \text { FKBP } & \Rightarrow & & & & & & \end{array}$

\begin{abstract}
Abb. 3. SDS-PAGE und Western Immunoblot. Zum Zeitpunkt der Induktion mit Anhydrotetrazyklin $(t=0 \mathrm{~min})$ und folgend alle 30 Minuten $(t=30,60,90,120,180)$ wurden Proben der Expressionskultur entnommen und nach elektrophoretischer Auftrennung das rekombinante Protein durch Western Immunoblot detektiert, wobei eine zeitabhängige Expressionszunahme bis zum Zeitpunkt $\mathrm{t}=180 \mathrm{~min}$ zu beobachten ist .
\end{abstract}

Die rekombinant exprimierten Proteine wurden im Anschluss affinitätschromatografisch aufgereinigt und Proben der aufgefangenen Wasch- und Elutionsfraktionen elektrophoretisch aufgetrennt. Durch Färbung der SDS-Gele mit Coomassie-Brillant-Blue-Lösung konnten die Elutionsfraktionen bestimmt werden, die rekombinantes Protein enthielten. 
In den Waschfraktionen 1 und 2 wurden alle nicht spezifisch bindenden Lysatbestandteile aus der Säulenmatrix gelöst (Abb. 4, $\mathrm{W}_{1}$ und $\mathrm{W}_{2}$ ). Dementsprechend enthielten die Fraktionen der folgenden Waschschritte keine weiteren Proteine $\left(\mathrm{W}_{3}\right.$ bis $\left.\mathrm{W}_{6}\right)$. Die rekombinanten Proteine wurden aus ihrer Bindung zu StrepTactin durch Desthiobiotin (Puffer E) spezifisch verdrängt und waren in der 2. bis 4. Elutionsfraktion als Banden von circa $15 \mathrm{kDa}$ detektierbar $\left(\mathrm{E}_{2}\right.$ bis $\mathrm{E}_{4}$ ). Das erhöhte Molekulargewicht ist durch den angehängten Strep-tag II zu erklären.

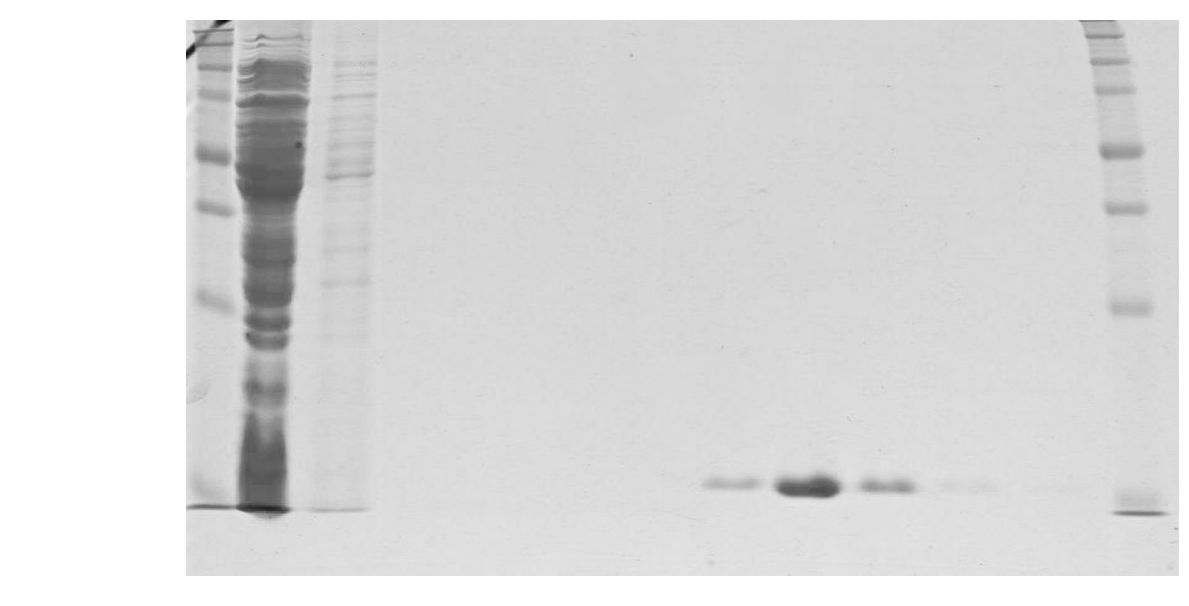

$\begin{array}{lllllllllllllll}\text { Fraktionen } & \mathrm{M}^{\mathrm{W}} & \mathrm{W}_{1} & \mathrm{~W}_{2} & \mathrm{~W}_{3} & \mathrm{~W}_{4} & \mathrm{~W}_{5} & \mathrm{~W}_{6} & \mathrm{E}_{1} & \mathrm{E}_{2} & \mathrm{E}_{3} & \mathrm{E}_{4} & \mathrm{E}_{5} & \mathrm{E}_{6} & \mathrm{M}\end{array}$

Abb. 4. SDS-PAGE und Coomassie-Färbung. Analysiert wurden Proben von Wasch- und Elutionsfraktionen der Affinitätsaufreinigung rekombinanter Proteine. Die Säule wurde durch Waschschritte von unspezifisch bindenden Proteinen gereinigt $\left(\mathrm{W}_{1-6}\right)$. Das rekombinante Protein wurde mit den Fraktionen $\mathrm{E}_{1}$ bis $\mathrm{E}_{6}$ aus der Säulenmatrix gelöst und als jeweils einzelne, scharf begrenzte Proteinbande bei $15 \mathrm{kDa}\left(\mathrm{E}_{2}-\mathrm{E}_{4}\right)$ im Gel nachgewiesen.

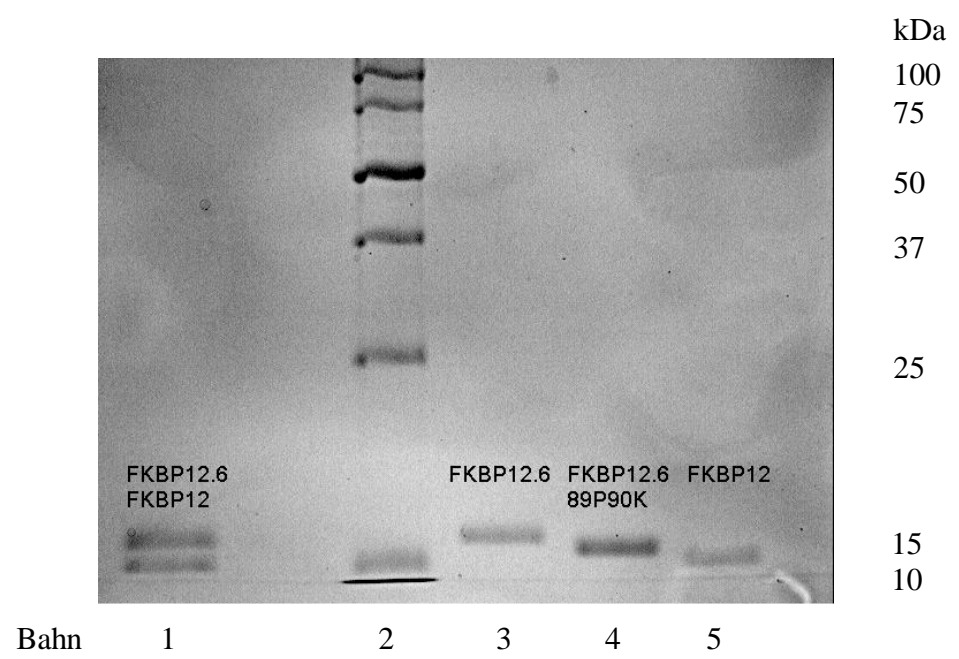

Abb. 5. SDS-PAGE-Analyse der FKBP-Varianten. FKBP12.6 und FKBP12.0 wurden aufgrund ihrer Molekülgröße durch die Elektrophorese deutlich voneinander getrennt (gemeinsam Bahn 1, Einzelauftragung Bahn 3 und 5). FKBP12.6 ${ }^{\mathrm{G} 89 \mathrm{PV} 90 \mathrm{~K}}$ zeigte im Vergleich zu FKBP12.6 ein schnelleres Laufverhalten im Gel (Bahn 4). Proteinstandard Bahn 2.(Quelle: AG Seidler) 
Durch elektrophoretische Auftrennung von Proben aus $E_{3}$ und $E_{4}$ auf hochauflösenden 12,5\%igen Gelen und anschließende Färbung mit Coomassie-Brillant-Blue konnten FKBP 12.0, 12.6 und $12.6^{\mathrm{G} 89 \mathrm{PV} 90 \mathrm{~K}}$ voneinander diskriminiert werden (Abb. 5)

\subsubsection{Calcineurinaffinitäts-Assay zur Untersuchung der Interaktion von FKBP mit FK506 und Calcineurin}

Das Molekül FK506 inhibiert nach Bindung an FKBP die Proteinphosphatase Calcineurin. Die Calcineurinbindungsaffinität von FKBP12.6 und FKBP12.6 ${ }^{\mathrm{G} 89 \mathrm{PV} 90 \mathrm{~K}}$ wurde indirekt anhand der Phosphatmengen bestimmt, die in einem kommerziellen Assay von Calcineurin aus einem Phosphopeptid-Substrat freigesetzt wurden.

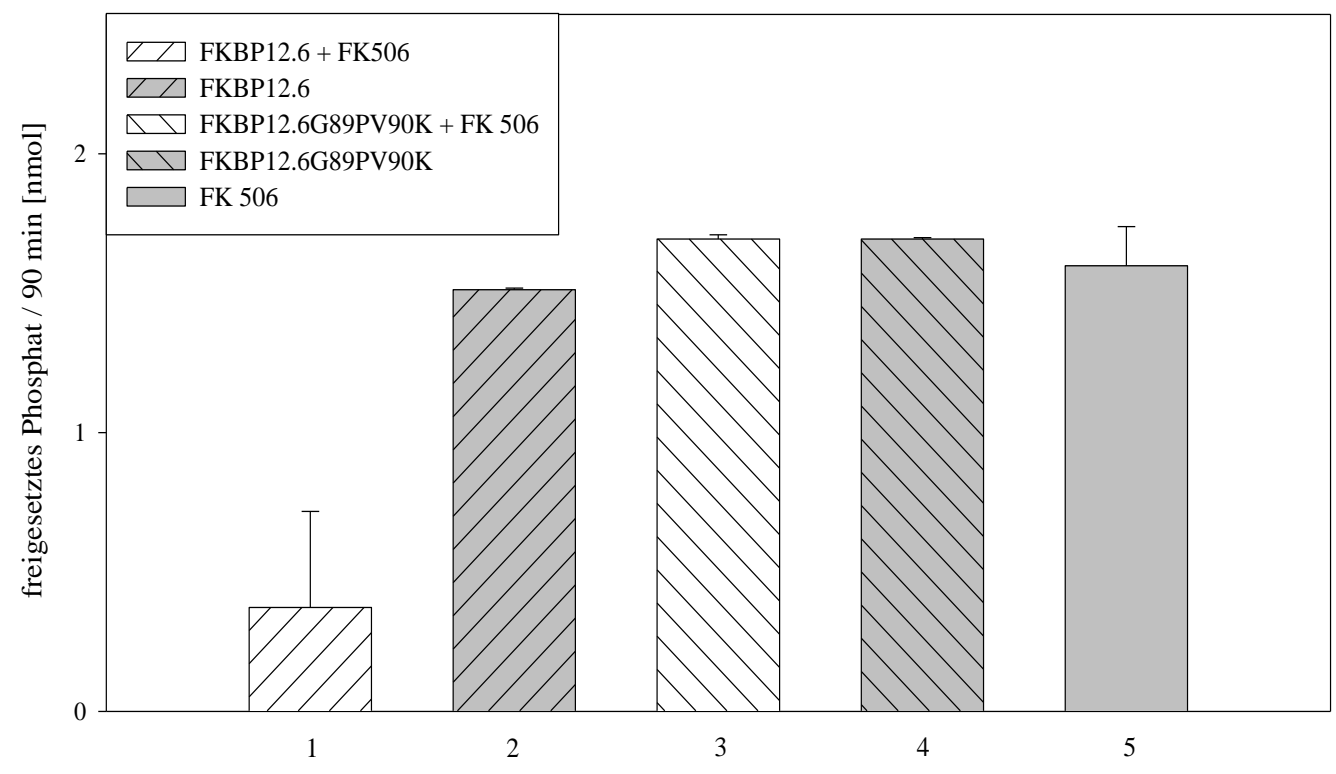

Abb. 6. Calcineurin-Assay. Von Calcineurin aus einem Phosphopeptidsubstrat in $90 \mathrm{~min}$ freigesetzte Phosphatmengen, veranschaulicht als Mittelwert \pm SEM.

Erwartungsgemäß setzte der Komplex aus FKBP12.6 und FK506 die Phosphataseaktivität des Calcineurins stark herab (Abb. 6, Säule 1). Nur 0,38 \pm 0,243 nmol des im Peptid-Substrat gebundenen Phosphates wurden freigesetzt, wohingegen FKBP12.6 allein (Säule 2) die Calcineurinaktivität in wesentlich geringerem Ausmaß reduzierte $(1,51 \pm 0,004 \mathrm{nmol}$ freies Phosphat). Im Vergleich dazu konnte die Anwesenheit von FKBP12.6 ${ }^{\text {G89PV90K }}$ (mit FK506: Säule 3 und ohne FK506: Säule 4) Calcineurin nicht inhibieren. Die freigesetzte Phosphatmenge betrug 1,69 \pm 0,01 nmol für FKBP ${ }^{\mathrm{G} 89 \mathrm{PV} 90 \mathrm{~K}}$ zusammen mit FK506 und 1,69 \pm 0,004 nmol für FKBP ${ }^{\mathrm{G} 89 \mathrm{PV} 90 \mathrm{~K}}$ allein. In einem Ansatz mit FK506 ohne FKBP wurden 1,6 \pm 0,095 nmol Phosphat gemessen (Säule 5). 


\subsubsection{Rotamase-Assay zum Nachweis erhaltener FK506-Affinität von FKBP12.6 ${ }^{\text {G89PV90K }}$}

Um auszuschließen, dass die Calcineurin-Inhibition durch FKBP12.6 ${ }^{\mathrm{G} 89 \mathrm{PV} 90 \mathrm{~K}}$ nicht aufgrund mangelnder FK506-Affinität ausbleibt, sondern auf fehlender Calcineurinbindung basiert, wurde der Rotamase-Assay durchgeführt. Die Rotamaseaktivität von FKBP wird durch Bindung an FK506 konzentrationsabhängig inhibiert. Eine durch FK506 induzierte Hemmung der Rotamaseaktivität beweist so eine erhaltene Bindungsaffinität der FKBP für FK506.
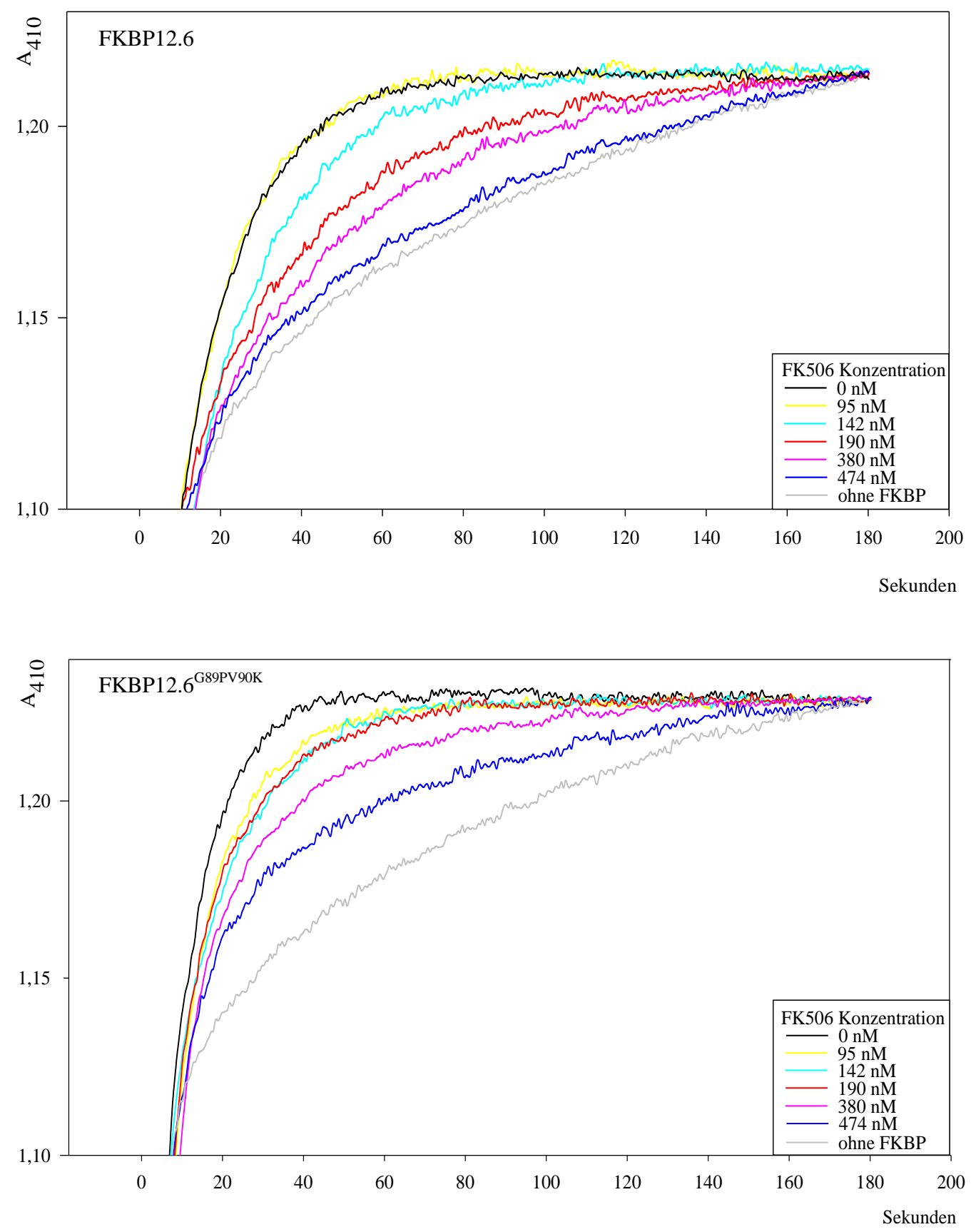

Abb. 7. Rotamase-Assay. Die bei $410 \mathrm{~nm}$ aufgezeichneten Reaktionskurven für FKBP12.6 (oben) und FKBP12.6 ${ }^{\mathrm{G} 89 \mathrm{PV} 90 \mathrm{~K}}$ (unten), versetzt mit $95 \mathrm{nM}$ (gelb), $142 \mathrm{nM}$ (türkis), $190 \mathrm{nM}$ (rot), $380 \mathrm{nM}$ (violett) und $474 \mathrm{nM}$ (blau) FK506, wurden auf den Kontrollansatz ohne FK506 (schwarz) normalisiert. Die graue Kurve beschreibt die Reaktion ohne FKBP. 
In den durchgeführten Assays konnte sowohl für FKBP12.6 als auch für FKBP12.6 ${ }^{\mathrm{G} 89 \mathrm{PV} 90 \mathrm{~K}}$ eine Korrelation von FK506-Konzentration und Inhibierung der Rotamaseaktivität nachgewiesen werden (Abb. 7).

\subsection{Kontrolle der Transfektionseffizienz rekombinanter Adenoviren in Kardiomyozyten}

\subsubsection{Bestimmung der für eine hohe Transfektionsrate benötigten Virusmenge durch den B-Galaktosidase-Assay}

Um die Effektivität der adenoviralen Transfektion adulter isolierter Kardiomyozyten abzuschätzen, wurde die Transfektionseffizienz anhand eines Adenovirus kontrolliert, welches B-Galaktosidase überexprimiert. Ziel dieses Assays ist es, die Virusmenge pro Kardiomyozyt (MOI) zu ermitteln, die einen möglichst hohen Anteil an transfizierten Myozyten gewährleistet und gleichzeitig eine unnötig hohe Virusexposition vermeidet. So soll verhindert werden, dass einzelne Myozyten mit unzureichender oder fehlender Transfektion die erwarteten Effekte in den Untersuchungen mit für FKBP kodierenden Adenoviren vermindern. Zudem sollen Seiteneffekte einer exzessiven Virusexpostion und damit Genexpression ausgeschlossen werden.

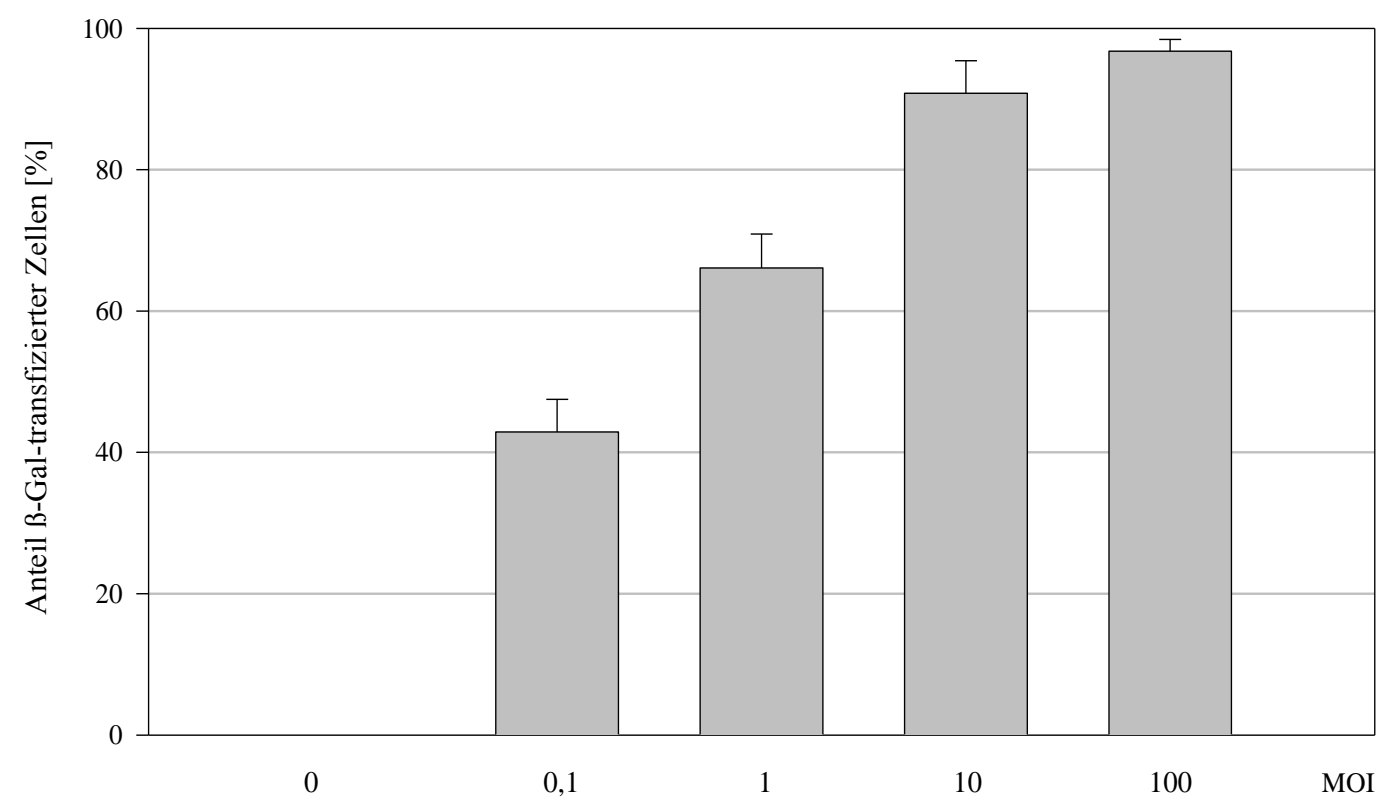

Abb. 8. ß-Galaktosidase-Assay. Die prozentualen Anteile blau gefärbter (ß-Galtransfizierter) Myozyten wurden für MOI 0, 0,1, 1, 10 und 100 ausgezählt und in Mittelwert \pm SEM graphisch dargestellt. Mit der Virusanzahl pro Myozyt (MOI) bei der Infektion stieg der Anteil transfizierter Zellen. 
Dazu wurden isolierte Myozyten mit dem für B-Gal-kodierenden Ad-LacZ-Virus in aufsteigenden Konzentrationen (MOI 0, 0,1, 1, 10, 100) infiziert. Nach Kultivierung und BGalaktosidase-Färbung wurden B-Gal-exprimierende Zellen unter dem Mikroskop ausgezählt. Bei einer MOI von 0,1 trugen 42,9 \pm 4,6 \% der isolierten Kardiomyozyten das BGalaktosidasegen. Bei MOI 1 stieg der Anteil transfizierter Zellen auf 66,1 \pm 4,8\%. Wurden die Zellen mit 10 Viren pro Myozyt infiziert (MOI 10), betrug der prozentuale Anteil ß-Galexprimierender Zellen 90,8 \pm 4,6 \%. Bei MOI 100 wurden 96,8 \pm 1,7 \% ß-Gal-positive Zellen protokolliert. Die Kultur ohneVirus zeigte keine $\beta$-Gal-Aktivität (Abb. 8).

\subsubsection{RT-PCR zum Nachweis spezifischer mRNA-Transkription in adenoviral transfizierten Kardiomyozyten}

Um die Transkription des adenoviral transfizierten FKBP ${ }^{\mathrm{G} 89 \mathrm{PV} 90 \mathrm{~K}}$-DNA-Konstrukts nachzuweisen, wurde Gesamt-RNA aus Myozytenkulturen isoliert, die in aufsteigenden Konzentrationen mit Ad-FKBP ${ }^{\mathrm{G} 89 \mathrm{PV} 90 \mathrm{~K}}$ infiziert worden waren. Das Transkript wurde nach Umschreiben der RNA in cDNA mit FKBP-spezifischen Primern amplifiziert, die in der PCR eine Produktlänge von 662 Basenpaaren erzeugten.

Nach elektrophoretischer Auftrennung im Agarosegel konnten dem FKBP ${ }^{\text {G89PV90K }}$-Konstrukt entsprechende amplifizierte Banden bei 662 bp detektiert werden, deren Intensität mit dem Anstieg der MOI korrelierte (Abb. 9). In der Kontrollkultur (ohne Virustransfektion, MOI 0) wurde kein FKBP ${ }^{\mathrm{G} 89 \mathrm{PV} 90 \mathrm{~K}}$-Amplikon nachgewiesen. Das Referenzgen Calsequestrin wurde in Lysaten aller Zellkulturen in annähernd gleichem Ausmaß amplifiziert und dient so der Demonstration gleicher cDNA-Ausgangsmengen in den verglichenen PCR-Ansätzen.

Auch in beiden Negativkontrollen $\left(\mathrm{H}_{2} \mathrm{O}\right.$ bzw. -RT) wurden keine Amplifikate detektiert. Als Positivkontrolle wurde humane FKBP12.6-DNA (+) eingesetzt.

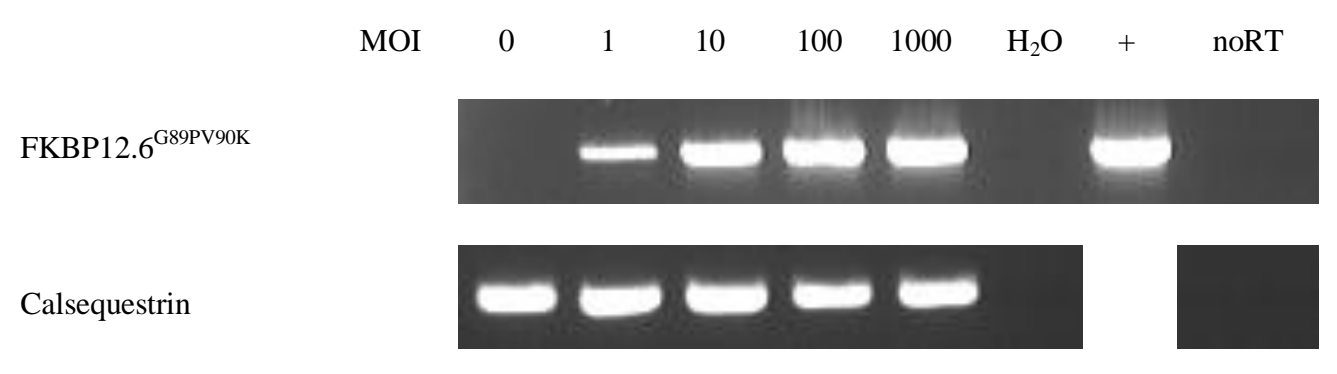

Abb. 9. RT-PCR. cDNA-Amplifikation von FKBP12.6 $6^{\mathrm{G} 89 \mathrm{PV} 90 \mathrm{~K}}$ und Calsequestrin mit spezifischen Primern aus FKBP12.6 ${ }^{\mathrm{G} 89 \mathrm{PV} 90 \mathrm{~K}}$-transfizierten Kaninchenmyozyten. Banden von FKBP12.6 ${ }^{\mathrm{G} 89 \mathrm{PV} 90 \mathrm{~K}}$ (bei $662 \mathrm{kDa}$ ) korrelierten in der Intensität mit der MOI. Calsequestrin wurde als Referenzgen in gleichbleibender Intensität bei $353 \mathrm{kDa}$ detektiert. Eine Positivkontrolle für Calsequestrin wurde nicht mitgeführt. 


\subsubsection{Western Immunoblot zum Nachweis der Expressionssteigerung von FKBP nach adenoviralem Gentranfer}

Zur Kontrolle der Proteinexpression des adenoviral transfizierten Konstruktes FKBP12.6 ${ }^{\mathrm{G} 89 \mathrm{PV} 90 \mathrm{~K}}$ wurden Lysate von Ad-FKBP12.6 ${ }^{\mathrm{G} 89 \mathrm{PV} 90 \mathrm{~K}}$-transfizierten Myozytenkulturen durch SDS-PAGE und folgenden Western Immunoblot untersucht.

In den Kulturen, die mit MOI 1, 10 und 100 des oben genannten Virus transfiziert worden waren, wurden Proteinbanden bei etwa 13 kDa detektiert. Die Intensität der Banden nahm mit Anstieg der MOI deutlich zu. In der untransfizierten Myozytenkultur (MOI 0) war erwartungsgemäß keine FKBP12.6 ${ }^{\mathrm{G} 89 \mathrm{PV} 90 \mathrm{~K}}$ entsprechende Proteinbande nachzuweisen (Abb. 10, obere Banden). Das endogen in den Zellen exprimierte FKBP12.0 wurde in allen Kulturen bis MOI 10 mit gleichbleibendem Ausmaß bei circa 12kDa detektiert (Abb. 10, untere Proteinbanden).

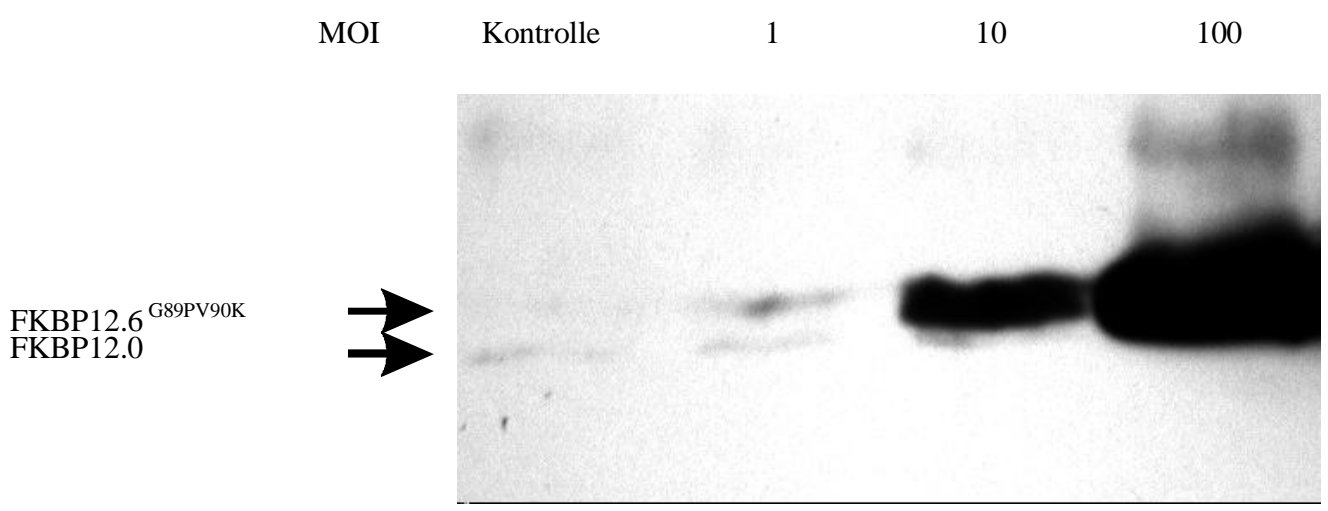

Abb. 10. Western Immunoblot zum Nachweis von FKBP. Während die Höhe der FKBP12.6 ${ }^{\mathrm{G} 89 \mathrm{PV} 90 \mathrm{~K}_{-}}$-Expression in adenoviral transfizierten Myozyten mit steigender Viruszahl (MOI) korrelierte (obere Banden), nahm die Expression von FKBP12.0 nicht zu (untere Banden). Bei MOI 100 wurde die FKBP12.0-Bande durch die Bande des transfizierten Proteins überdeckt.

\subsection{Messung der relativen Zellverkürzung adenoviral transfizierter Kardiomyozyten}

Isolierte Myozyten wurden mit Ad-FKBP12.6 ${ }^{\mathrm{G} 89 \mathrm{PV} 90 \mathrm{~K}}$ bzw. Ad-LacZ als Kontrolle transfiziert und nach Kultivierung in einem elektrischen Feld unter 1Hz-Stimulation kontrolliert zum Schlagen gebracht.

Die relative Zellverkürzung der mit MOI 10 transfizierten Zellen war zwischen den untersuchten Myozytenkulturen nicht signifikant unterschiedlich (Abb. 11, oben). Bei FKBP12.6 $6^{\mathrm{G} 89 \mathrm{PV} 90 \mathrm{~K}}$-überexprimierenden Zellen betrug die relative Zellverkürzung 2,69 $\pm 0,1 \%$ 
( $\mathrm{n}=116)$ und für Ad-LacZ-transfizierte 2,78 $\pm 0,11 \%(\mathrm{n}=120, \mathrm{p}=0,53)$. Die Untersuchung des gleichen Parameters bei MOI 50 ergab eine signifikant geringere relative Zellverkürzung für Ad-FKBP12.6 ${ }^{\mathrm{G} 89 \mathrm{PV} 90 \mathrm{~K}}$-transfizierte Zellen $(3,87 \pm 0,17 \%, \mathrm{n}=112)$ im Vergleich zu B-Galüberexprimierenden Myozyten (4,46 $\pm 0,18 \%, \mathrm{n}=108, \mathrm{p}=0,019)$ (Abb. 11, unten).

Die übrigen untersuchten Parameter ergaben keine statistisch signifikanten Unterschiede.
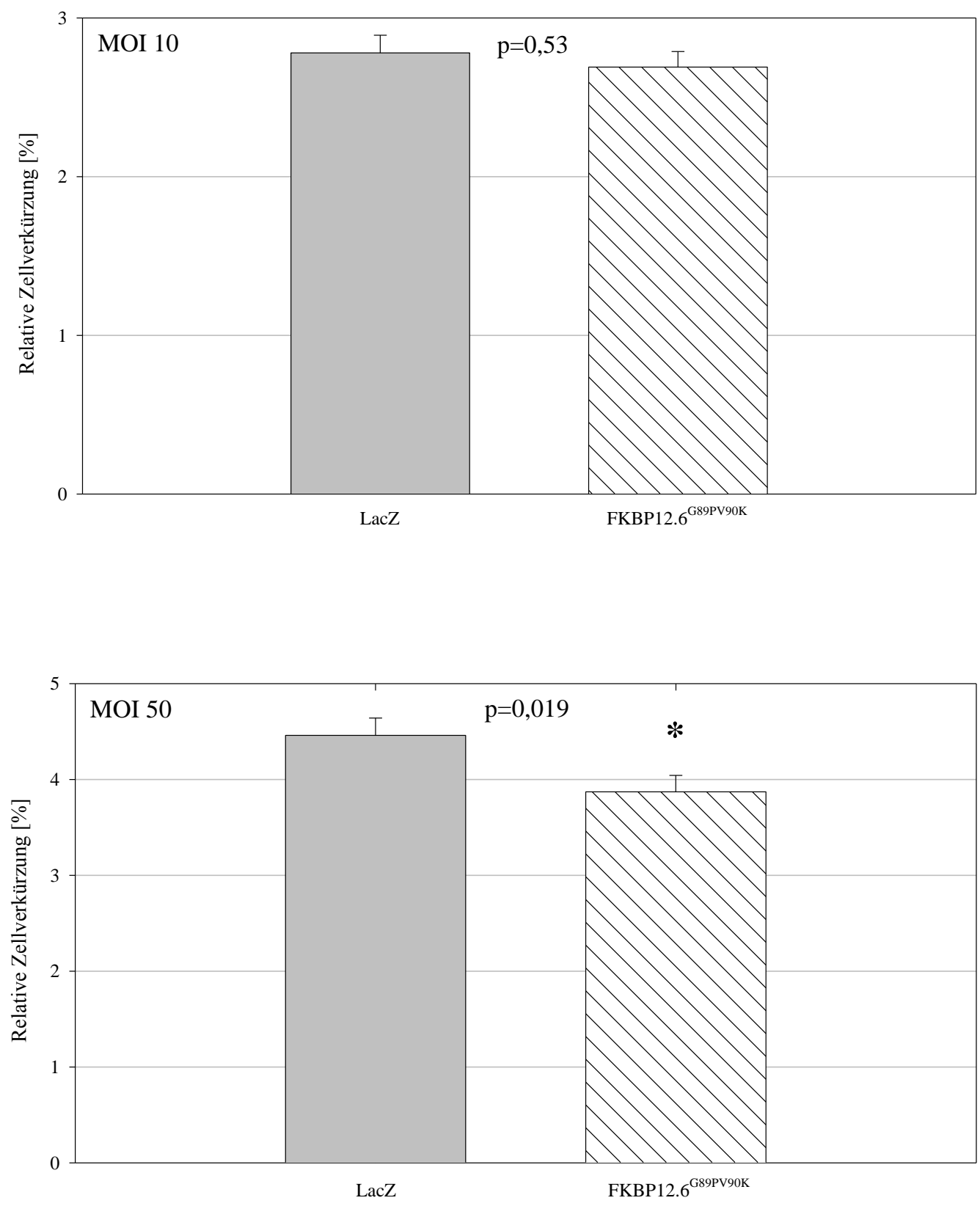

Abb. 11. Relative Zellverkürzung. oben: FKBP12.6 $6^{\mathrm{G} 89 \mathrm{PV} 90 \mathrm{~K}}$ - überexprimierende Kaninchenmyozyten $(n=116)$ zeigten keinen Unterschied $\mathrm{zu}$ Ad-LacZ-transfizierten Zellen $(n=120)$. unten: signifikant geringere relative Zellverkürzung der FKBP12.6 ${ }^{\mathrm{G} 9 \mathrm{PV} 90 \mathrm{~K}}$-Gruppe $(n=112)$ im Vergleich zur Kontrollgruppe $(n=118)$. Dargestellt sind Mittelwerte \pm SEM. 


\section{DISKUSSION}

\subsection{Die Interaktion zwischen RyR2 und FKBP12.6}

Ziel der vorliegenden Arbeit war es, zu untersuchen, ob FKBP12.6 einen Einfluss der $\mathrm{Ca}^{2+}{ }_{-}$ abhängigen Phosphatase Calcineurin auf die Funktion des RyR in der Herzmuskelzelle vermittelt.

Die Assoziation von FKBP12.6 mit dem RyR2 der Herzmuskelzelle wurde erstmals durch Marx et al. (2000) nachgewiesen. Prestle et al. (2001) zeigten in isolierten primären Herzmuskelzellen, dass eine FKBP12.6-Überexpression den diastolischen $\mathrm{Ca}^{2+}$-Verlust über den RyR vermindert und durch den konsekutiv erhöhten SR-Ca ${ }^{2+}$-Gehalt die Koffeininduzierten Kontraktionen sowie die relative Zellverkürzung verstärkt werden. Dies wurde in weiteren Arbeiten unter anderem auch auf eine koordiniertere Öffnung der Kanäle („,coupled gating“) in Anwesenheit von FKBP12.6 zurückgeführt (Marx et al. 2001, Loughrey et al. 2004).

Die Rolle von FKBP12.6 in der Genese der Herzinsuffizienz ist bis heute nicht endgültig geklärt. In der insuffizienten Herzmuskelzelle liegt wahrscheinlich eine Hyperphosphorylierung des RyR2 durch die PKA vor, was zu einer geringeren Affinität des FKBP12.6 und damit zu einer vermehrten Offenwahrscheinlichkeit des RyR mit erhöhter $\mathrm{Ca}^{2+}$-Freisetzung aus dem SR und folgender Erhöhung der zytolischen $\mathrm{Ca}^{2+}$-Konzentration führt (Marx et al. 2000, Yano et al. 2000). FKBP12.6-Knockout-Mäuse wiesen aber keinen herzinsuffizienten Phänotyp auf, sondern eine erhöhte Arrhythmieneigung mit Katecholaminsensitiven polymorphen ventrikulären Tachykardien (CPVT) (Wehrens et al. 2003).

Der Ryanodin-Rezeptor als größter bekannter Ionenkanal wird mittlerweile als Multiproteinkomplex verstanden. Neben FKBP greifen zahlreiche Regulatoren wie Proteinkinase A und dessen Ankerprotein mAKAP, Proteinphosphatase 1 und 2a (Marx et al. 2000) sowie Sorcin (Seidler et al. 2003) und die Proteinphosphatase 2b, Calcineurin (Cameron et al. 1995), mit unterschiedlicher Wirkung an den Kanal an.

Welche Rolle Calcineurin in diesem Zusammenhang spielt, ist Gegenstand dieser Arbeit. Eine $\mathrm{Ca}^{2+}$-konzentrationsabhängige Bindung von Calcineurin über FKBP an den RyR konnte bereits nachgewiesen werden (Cameron et al. 1995, Bandyopadhyay et al. 2000). Eine Dissoziation des FKBP-Calcineurin-Komplexes bewirkte vermehrte spontane $\mathrm{Ca}^{2+}$-Ströme über den RyR. Dementsprechend wurde in der vorliegenden Arbeit untersucht, inwiefern sich 
eine Calcineurin-bindungsdefiziente FKBP12.6-Mutante das Kontraktionsverhalten der Herzmuskelzelle verändert und welche Auswirkungen eine fehlende Calcineurin-Bindung auf die endogenen Eigenschaften von FKBP12.6 hat.

\subsection{Eigenschaften von FKBP12.6 ${ }^{\mathrm{G} 89 \mathrm{PV} 90 \mathrm{~K}}$}

Bei FKBP12.6 ${ }^{\mathrm{G} 89 \mathrm{PV} 90 \mathrm{~K}}$ handelt es sich um eine Mutante der FKBP12.6-Wildtyp-Form, die in dieser Arbeit erstmals beschrieben wird. Gleiche Mutationen in der FKBP12.0-Isoform verursachten eine starke Herabsetzung der Affinität zu Calcineurin. Obwohl die FKBPIsoformen eine große Ähnlichkeit untereinander aufweisen, ist es dennoch denkbar, dass trotz gleicher Mutationen in FKBP12.6 z.B. über Unterschiede in der Tertiärstruktur des Proteins die Calineurinbindungsfähigkeit erhalten bleibt. Über den Calcineurinaffinitäts-Assay (siehe 3.2.2., Seite 41) konnte in dieser Arbeit nachgewiesen werden, dass die Calcineurinaktivität von der hier hergestellten FKBP12.6 ${ }^{\mathrm{G} 89 \mathrm{PV} 90 \mathrm{~K}}$-Isoform nicht beeinflusst und in Kombination mit FK506 auch nicht inhibiert werden kann. In diesem Assay liegt FKBP als rekombinant hergestelltes Protein als Bindungspartner von Calcineurin und FK506 in einem physiologisch gepufferten Milieu vor. Ein synthetisches phosphoryliertes Peptid dient als Calcineurinsubstrat. Es wird durch Calcineurin dephosphoryliert und im Folgenden eine Farbreaktion auf freies Phosphat entwickelt, anhand derer im Vergleich zu einer Standardverdünnung verschiedener Phosphatkonzentrationen auf die Phosphataseaktivität von Calcineurin geschlossen werden kann.

Für diesen Assay waren zunächst einige Etablierungsschritte notwenig. Zum einen mussten die FKBP-Isoformen rekombinant erzeugt werden. Zum anderen hatten insbesondere die Reinheit und Konzentration der eingesetzten Proteine höchsten Reinheitsansprüchen zu genügen, um reproduzierbare Ergebnisse zu gewährleisten. Da die verwendeten FKBPIsoformen nicht kommerziell erhältlich sind, wurden in E.coli Plasmide für diese Isoformen transfiziert und entsprechend dem Protokoll rekombinant exprimiert und aufgereinigt (siehe 2.2., Seite 19). Die Ergebnisse zeigten einen sehr hohen Reinheitsgrad des FKBP in den einzelnen Fraktionen (siehe Abb. 4 und 5, Seite 40).

$\mathrm{Da}$ es sich beim Calcineurinaffinitäts-Assay um einen zeitabhängigen Substratumsatznachweis handelt, wurde die Entwicklungszeit so gewählt, dass auch geringe Änderungen der Calcineurinaktivität mit großen Farbänderungen assoziiert waren, so dass weder Substrat noch FKBP-Proteinmenge limitierend für die enzymatische Reaktion waren. 
Die Analyse wurde vergleichend, das heißt mit beiden FKBP-Isoformen im selben Assay durchgeführt, um eine zusätzliche Sicherheit in Hinblick auf eine Reduktion der Inter-AssayVariabilität zu erreichen.

Erwartungsgemäß zeigte ausschließlich FKBP12.6, nicht aber FKBP12.6 ${ }^{\mathrm{G} 89 \mathrm{PV} 90 \mathrm{~K}}$ eine signifikante Reduktion der Calcineurinphosphataseaktivität in Anwesenheit von FK506. (siehe Abb. 6, Seite 41). Da Calcineurin nur in Anwesenheit von FKBP FK506-vermittelt inhibiert werden kann, weisen diese Ergebnisse darauf hin, dass die FKBP-Mutante keine suffiziente Calcineurininteraktion eingehen kann. Demzufolge ist FKBP12.6 ${ }^{\mathrm{G} 89 \mathrm{PV} 90 \mathrm{~K}}$ geeignet, FKBP12.6 kompetitiv in der Eigenschaft als Calcineurin-Ankerprotein zu verdrängen.

Dennoch bestand ein Risiko, dass Calcineurin weiterhin von FKBP12.6 ${ }^{\mathrm{G} 89 \mathrm{PV} 90 \mathrm{~K}}$ gebunden wird, aber eine herabgesetzte FK506-Bindungsaffinität des Komplexes zu den beobachteten Effekten im Calcineurin-Assay führt. Eine herabgesetzte FK506-Bindungsaffinität würde eine verminderte Bindung am RyR vermuten lassen, da von einigen Autoren postuliert wird, dass FKBP an eine „FK506-ähnliche Region“ am RyR angreift (Cameron et al. 1995). Dies ist allerdings äußerst spekulativ, da die genaue Bindungsstelle sowie deren sterische Eigenschaften am RyR bis dato unbekannt ist.

Um die Affinität der Mutante für FK506 zu untersuchen, wurde die Bindung von FK506 an FKBP12.6 $6^{\mathrm{G} 89 \mathrm{PV} 90 \mathrm{~K}}$ indirekt durch den Rotamase-Assay (siehe 2.4., Seite 24) untersucht. Dieser Assay basiert auf der bereits seit langem bekannten und gut untersuchten Eigenschaft der FKBP-Isoformen, eine Rotamase-Aktivität (Peptidyl-prolyl-cis-trans-Isomeraseaktivität) aufzuweisen (Fischer et al. 1989). Durch die Bindung des Immunsuppressivums FK506 an die jeweilige FKBP-Isoform kann diese Enzymaktivität nahezu unterdrückt werden (Harding et al. 1989). Eine fehlende Inhibition dieser natürlichen FKBP-Eigenschaft würde ein Ausbleiben der FK506-Bindung nahelegen.

Die in dieser Arbeit durchgeführten Rotamase-Assays wurden mit den identischen rekombinanten Proteinen, die zuvor im Calcineurinaffinitäts-Assay eingesetzt wurden, durchgeführt.

Sowohl für FKBP12.6 als auch FKBP12.6 $6^{\mathrm{G} 89 \mathrm{PV} 90 \mathrm{~K}}$ zeigte sich eine klare Dosisabhängigkeit von FK506 bei der Konformationsumstellung eines spezifischen Substrates (Suc-Ala-LeuPro-Phe-p-nitroanilid). Obwohl die Analyse nicht quantitativ durchgeführt wurde, zeigt der Rotamase-Assay zumindest qualitativ eine Affinität der Isoformen zu FK506 (Abb. 7, Seite 42). Demnach konnte davon ausgegangen werden, dass der ausgebliebene inhibitorische Effekt von FK506 auf FKBP12.6 $6^{\mathrm{G} 89 \mathrm{PV} 90 \mathrm{~K}}$ im Calcineurinaffinitäts-Assay nicht auf einer fehlenden FK506-Bindungsaffinität der Mutante beruht. 


\subsection{Kontrolle der Genübertragung in adulte Kaninchenmyozyten}

Die Rolle von FKBP12.6 beim EC-Coupling der Herzmuskelzelle wurde durch Prestle et al. (2001) am Kaninchenmodell gezeigt. Dazu wurde ein adenoviral vermittelter Gentransfer genutzt, der zur Überexpression des Proteins führte. Um eine möglichst genaue Vergleichsmöglichkeit zu den Voruntersuchungen zu schaffen und die Unterschiede zur Calcineurin-bindungsdefizienten Mutante aufzuzeigen, wurde die gleiche Herangehensweise in der vorliegenden Arbeit genutzt. Vor allem eignen sich Kaninchenmyozyten aufgrund ihrer hohen Ähnlichkeit zu menschlichen Herzmuskelzellen hinsichtlich des $\mathrm{Ca}^{2+}$-Haushaltes besser als Herzmuskelzellen von Nagetieren.

Zum Gentransfer wurde ein Adenovirus generiert, das die DNA der FKBP12.6-Mutante als Expressionskonstrukt enthielt (Ad-FKBP12.6 $6^{\mathrm{G} 89 \mathrm{PV} 90 \mathrm{~K}}$ ).

Der adenovirale Gentransfer selbst hat nach derzeitigem Kenntnisstand einen zu vernachlässigenden Einfluss auf die Kontraktilität der Herzmuskelzelle (Rust et al. 1998, Lehnart et al. 2000). Dennoch wurden die jeweiligen Kontrollzellreihen mit einem für BGalaktosidase kodierenden Virus (Ad-LacZ) transfiziert, um eine bessere Vergleichbarkeit zu gewährleisten und systematische Einflüsse z.B. durch Aktivität des CMV-Promotors in der Zelle auszugleichen.

Die sehr hohe und konstant reproduzierbare Transfektionseffizienz des Adenovirusmodells konnte im B-Galaktosidase-Assay nachgewiesen werden (siehe Abb. 8, Seite 43). Hier zeigt sich bis einschließlich einer Viruszahl von 10 Viren pro Kardiomyozyt (MOI 10) eine lineare Zunahme der transfizierten Zellzahl. Zwischen MOI 10 und 100 kommt es zu einem zunehmenden Sättigungseffekt, so dass in diesem Bereich und darüber hinaus die Steigerung der Viruszahl keine zusätzliche Transfektionseffizienzsteigerung erwarten lässt.

Die Kontrolle der Transfektionseffizienz auf RNA- und Proteinebene erfolgte vor Durchführung der Experimente durch RT-PCR bzw. Western Immunoblot. Diese konnten abhängig von der verwendeten Virusmenge (MOI) einen selektiven Anstieg der RNA- bzw. Proteinmengen für FKBP12.6 ${ }^{\mathrm{G} 89 \mathrm{PV} 90 \mathrm{~K}}$ zeigen (siehe Abb. 9, Seite 44 bzw. Abb. 10, Seite 45). Dabei konnte durch Mitführung von Negativproben $\left(\mathrm{H}_{2} \mathrm{O}\right.$, keine RT) eine Kontamination durch Virus-DNA ausgeschlossen werden. Auch die Möglichkeit, dass nur die endogen vorliegende FKBP-DNA vervielfältigt wurde, konnte bei Nichtvorhandensein einer Bande in der Zellreihe ohne Virus (MOI 0) sowie einen langsamen Bandengrößenanstieg mit steigender Viruslast ausgeschlossen werden.

Ebenso korrellierte im Western Blot die Bandengröße mit der steigenden MOI. FKBP12.6 und FKBP12.0, die aufgrund der Aminosäuresequenz und einer zusätzlichen 
Phosphorylierung im FKBP12.6-Molekül um etwa 127 Da differieren (Sewell et al. 1994), ließen sich unter Verwendung eines hochauflösenden Gels sicher voneinander diskriminieren. Das leichtere FKBP12.0 war in gleichen Mengen in allen Ansätzen nachweisbar.

Für die Kontraktilitätsmessungen an Kardiomyozyten wurde je eine Zellreihe mit einer MOI von 10 und 50 gewählt, da bei ausreichender Transfektionseffizienz (siehe oben) bereits auf RNA- beziehungsweise Proteinebene Genexpressionslevel nachweisbar waren, die deutlich über dem endogenen Expressionsniveau lagen. Höhere Viruskonzentrationen wurde zur Vermeidung von Seiteneffekten der unphysiologisch hohen Proteinproduktion vermieden.

Der adenoviral vermittelte Gentransfer ist eine zeitlich beeinflussbare Methode. So weiß man, dass die Überexpression des eingebrachten Proteins ein Maximum zwischen dem ersten und siebten Tag nach Infektion erreicht und dann wieder auf nicht detektierbare Level abfällt (Rosenfeld et al. 1991). Zusammen mit der begrenzten Lebensfähigkeit von isolierten Zellen wurden sämtliche Kontraktilitätsuntersuchungen am zweiten Tag nach Virus-Transfektion durchgeführt.

\subsection{Myozytenkontraktionsmessungen}

Die Methode der Kontraktionsmessung an isolierten Kardiomyozyten nach adenoviralem Gentransfer ist eine validierte, wiederholt angewendete Methode, die vielfach publiziert wurde (Prestle et al. 2001, Seidler et al. 2003, Teucher et al. 2004). Dabei besteht das Problem, einen optimalen Kompromiss aus Transfektionseffizienz und Expressionsniveau zu finden. Bei niedriger MOI ist, wie in 3.3.1. (Seite 43) beschrieben, ein Großteil der Kardiomyozyten nicht transfiziert. Bei höherer MOI kommt es dagegen zu einer exzessiven Proteinexpression (siehe Abb. 10, Seite 45). Daher wurden zwei Transfektionsdosen, MOI 10 und MOI 50, zur Untersuchung der relativen Zellverkürzung gewählt.

Trotz demonstrierter Effizienz der Virustransfektion mit selektiver Erhöhung der Proteinexpression zeigte sich bei einer MOI von 10 kein signifikanter Unterschied in der relativen Zellverkürzung der Kardiomyozyten im Vergleich zu kontrolltransfizierten Zellen (Abb. 11, Seite 46). Dagegen wiesen die mit MOI 50 behandelten Zellen eine verringerte relative Zellverkürzung auf $(\mathrm{p}=0,019)$. Dementsprechend kann angenommen werden, dass Calcineurin tatsächlich einen Einfluss auf den RyR2 im Sinne einer Verminderung der diastolischen Öffnungswahrscheinlichkeit (Verminderung des $\mathrm{Ca}^{2+}$-Lecks) bzw. eine Verbesserung des coupled gating (siehe oben) bewirkt.

Die hier erhobenen Befunde zur relativen Zellverkürzung sind durchaus überraschend, da sie im deutlichen Gegensatz zu vorherigen Befunden unserer Arbeitsgruppe stehen, in denen 
unmutiertes FKBP (Wildtyp) adenoviral in isolierten Kardiomyozyten exprimiert wurde. Prestle et al. (2001) und Loughrey et al. (2004) konnten übereinstimmend und reproduzierbar eine signifikante Zunahme der relativen Zellverkürzung nach FKBP12.6-Transfektion zeigen. Die hier untersuchte FKBP12.6 ${ }^{\mathrm{G} 89 \mathrm{PV} 90 \mathrm{~K}}$-Mutation führt demnach $\mathrm{zu}$ einem vollständigen Verlust dieses Effekts bei MOI 10 und sogar zu einer Verschlechterung der relativen Zellverkürzung bei MOI 50. Dementsprechend weisen die hier erhobenen Befunde klar auf eine besondere Rolle der Konformationsgebung an den Aminosäuren 89 und 90 und eine Rolle des Calcineurins in der Regulation des RyR2 hin.

Weitere Untersuchungen zur Rolle von Calcineurin am RyR2 sind aber unerlässlich, da ein direkter Nachweis der Komplexbildung aus RyR, Calcineurin und FKBP noch nicht erbracht wurde.

Kritisch ist in Zusammenhang mit dieser Untersuchungsmethode immer das Fehlen des ZellZell-Kontaktes und damit die fehlende Kommunikation innerhalb des Zellverbandes anzumerken. So könnte es erklärlich sein, dass nur leichte Veränderungen des Proteinexpressionslevels sich in noch nicht nach außen messbaren Veränderungen auf z.B. die Kontraktilität der Zelle auswirken. Des Weiteren könnten zahlreiche untransfizierte Zellen, wie sie nach dem $\beta$-Galaktosidase-Assay zu erwarten sind $(9,2 \% \pm 4,6 \%$, siehe 3.3.1., Seite 43), erklären, warum in der MOI 10-Gruppe kein signifikanter Unterschied bezogen auf die relative Zellverkürzung messbar war.

Jedoch ist in diesem Zusammenhang anzumerken, dass Prestle et al. (2001) unter gleichen Bedingungen eine signifikante Zunahme der relativen Zellverkürzung bei MOI 10 nachweisen konnten.

\subsection{Bewertung der Ergebnisse}

Sämtliche Eigenschaften der hier erstmals generierten Calcineurin-bindungsdefizienten Mutante wurden ausschließlich anhand rekombinanter Proteine in vitro untersucht. Systematische Fehler, auf beispielsweise fehlenden unbekannten Interaktionspartnern basierend, sind somit nicht ausgeschlossen. Da aber bereits viele andere Untersuchungen an FKBP in vitro durchgeführt wurden, bleibt zumindest die Vergleichbarkeit der verschiedenen Untersuchungen untereinander erhalten.

Die in den Assays verwendeten rekombinanten Proteine (FKBP12.6 und FKBP12.6 ${ }^{\mathrm{G} 89 \mathrm{PV} 90 \mathrm{~K}}$ ) wurden in E.coli und nicht in eukaryotischen Zellen hergestellt. Da es sich hierbei um eine bewährte Methode der artifiziellen Proteinherstellung handelt, sollte dies für die Analyse der 
FKBP12.6-Mutante aber keinen limitierenden Faktor darstellen. Posttranslationale Modifikationen von FKBP sind zudem nicht als funktional relevant identifiziert worden.

Dass eine Bindung von FKBP12.6 ${ }^{\mathrm{G} 89 \mathrm{PV} 90 \mathrm{~K}}$ am RyR2 stattfindet, kann indirekt aus dem Rotamase-Assay angenommen werden, da die Interaktion wahrscheinlich über eine FK506ähnliche Domäne des RyR erfolgt. Da der Versuch nur qualitativ durchgeführt wurde, lässt er so keine Aussage darüber zu, wie stark FK506 interagiert und wie stark dementsprechend die Bindung zwischen RyR und FKBP ist.

In den Kontraktilitätsuntersuchungen zeigte sich bei MOI 50 eine reduzierte relative Zellverkürzung in FKBP12.6 ${ }^{\mathrm{G} 89 \mathrm{PV} 90 \mathrm{~K}}$-transfizierten Kardiomyozyten. Es zeigte sich allerdings kein Effekt bei MOI 10. Daher stellt sich die Frage, ob das mutierte Protein eventuell aufgrund einer herabgesetzten Affinität zum RyR nicht in der Lage war, endogen gebundenes FKBP12.6 zu verdrängen. Da die Untersuchungen im Rotamase-Assay nur qualitativ durchgeführt wurden, bleibt eine herabgesetzte Bindungsaffinität von FKBP12.6 ${ }^{\mathrm{G} 89 \mathrm{PV} 90 \mathrm{~K}}$, wie oben erläutert, denkbar.

Vermutet werden könnte ebenfalls, dass Calcineurin nur eine untergeordnete Rolle im FKBPRyR-Komplex spielt. In diesem Zusammenhang ist es wichtig, dass die Arbeitsgruppe Marks et al. (1990) in Immunopräzipitaten des RyR kein Calcineurin nachweisen konnte. Dem gegenüber stehen aber Untersuchungen, die bei fehlender Calcineurinwirkung am RyR vermehrte unkontrollierte $\mathrm{Ca}^{2+}$-Ströme über den RyR berichten (Bandyopadhyay et al. 2000). Da die Wirkung der FKBP-Mutante nur über Kompetition mit endogenem FKBP12.6 erklärbar ist, ist es wahrscheinlich, dass ein Effekt erst durch höhere Dosen der Mutante zu erwarten ist, bei der alle vier FKBP-Bindungsstellen durch diese besetzt sind. Dazu passt der beobachtete Effekt bei MOI 50. Hier findet sich eine negative Inotropie mit verminderter relativer Zellverkürzung. Sollte dieser Effekt tatsächlich auf der aufgehobenen CalcineurinRyR-Interaktion beruhen, legt dies nahe, dass Calcineurin positiv inotrope Eigenschaften durch Dephosphorylierung des kardialen RyR entfaltet.

Der RyR ist ein bekanntermaßen vielfach phosphoryliertes Protein und bisherige Arbeiten konnten Phosphorylierungen durch die PKA sowie CamII-Kinasen eindeutig nachweisen (Marx et al. 2000). Obwohl die Phosphatasen 1 und 2a mit dem RyR assoziiert sind, ist bislang unklar, inwiefern dies die PKA- und CamII-Kinase-vermittelte Phosphorylierung beeinflusst.

In diesem Zusammenhang ist es attraktiv anzunehmen, dass die wahrscheinlich PKAabhängige Assoziation von FKBP und RyR direkt durch eine FKBP-bindende Phosphatase einem negativen Rückkopplungsmechanismus unterliegt. 
Da sich das Vorliegen der FKBP12.6-Mutante jedoch erst in einem die physiologischen Grenzen der FKBP-Expression überschreitenden Bereich durch negative Inotropie auswirkt (MOI 50 versus MOI 10), sind weitere Arbeiten erforderlich, um die Rolle von Calcineurin in der FKBP-Regulation am RyR zu sichern.

Mögliche Ansätze wären eine FRET-basierte (Fluorenszenz-Resonanz-Energie-Transfer) invitro- oder in-vivo -Analyse der potentiellen Interaktionspartner. Derlei Untersuchungen sind in der letzten Zeit bei Phosphatasen- und Kinasen-abhängigen Protein-Protein-Interaktionen zur Anwendung gekommen (Rochais et al. 2007). 


\section{ZUSAMMENFASSUNG}

Der Ryanodin-Rezeptor (RyR) als größter bekannter Ionenkanal der Herzmuskelzelle wird als Multiproteinkomplex verstanden. Eine Vielzahl von endogenen Kinasen und Phosphatasen interagiert mit dem RyR und man vermutet, dass dieser durch Phosphorylierung und Dephosphorylierung seitens seiner Bindungspartner in seiner Offenwahrscheinlichkeit und seiner Affinität zu regulatorischen Proteinen und damit in seiner Aktivität gesteuert wird. An den RyR2, die Isoform, die hauptsächlich in der Herzmuskelzelle vorkommt, bindet FKBP12.6. FKBP weisen eine intrinsische Peptidyl-prolyl-cis-trans-Isomeraseaktivität (Rotamase-Aktivität) auf, deren Bedeutung am RyR noch nicht bekannt ist. Dagegen gilt als gesichert, dass FKBP12.6 nach Bindung an den RyR2 dessen Offenwahrscheinlichkeit herabsetzt und so den $\mathrm{Ca}^{2+}$-Verlust in der Diastole verringert. Der so über FKBP12.6 erhöhte $\mathrm{Ca}^{2+}$-Gehalt des SR sowie die FKBP-abhängig koordiniertere Öffnung der RyR untereinander (,,coupled gating“) führen zu einer Verbesserung der relativen Zellverkürzung.

Es ist bekannt, dass die Phosphorylierung des RyR2 durch PKA, wie sie z.B. im Rahmen einer Herzinsuffizienz beobachtet wird, zur Dissoziation des FKBP12.6/RyR-Komplexes führt. Die Folgen sind erhöhter $\mathrm{Ca}^{2+}$-Verlust über den RyR mit Erhöhung der zytosolischen $\mathrm{Ca}^{2+}$-Konzentration, was eine Arrhythmieneigung der Zelle bedingt. Dies konnte auch in FKBP12.6-Knockout-Mäusen nachgewiesen werden.

Da man annimmt, dass viele Bindungspartner des RyR zum jetzigen Zeitpunkt noch nicht identifiziert wurden beziehungsweise die Funktion von bekannten assoziierten Proteinen nicht geklärt ist, liegt die Vermutung nahe, dass die FKBP-Wirkung am RyR durch zusätzliche Bindungspartner beeinflusst wird.

In der hier vorliegenden Arbeit wurde erstmals eine Calcineurin-bindungsdefiziente FKBP12.6-Mutante generiert (FKBP12.6 $6^{\mathrm{G} 89 \mathrm{PV} 90 \mathrm{~K}}$ ), um die funktionelle Bedeutung der FKBPCalcineurin-Interaktion $\mathrm{zu}$ untersuchen. Es konnte nachgewiesen werden, dass die FKBP12.6 $6^{\mathrm{G} 89 \mathrm{PV} 90 \mathrm{~K}}$-Mutante Calcineurin weder binden noch FK506-abhängig inhibieren kann, wohingegen die endogene Rotamase-Aktivität von FKBP12.6 unbeeinträchtigt bleibt. Durch adenoviral vermittelte Überexpression wurde an isolierten Kardiomyozyten die Auswirkung von FKBP12.6 ${ }^{\text {G89PV90K }}$ auf die Kontraktilität der Zelle untersucht. Dabei fand sich bei gering erhöhter Expression der Mutante (MOI 10) kein Unterschied zur kontrolltransfizierten Zellreihe. Ab einer MOI 50 zeigte sich ein negativ inotroper Effekt der FKBP12.6 ${ }^{\mathrm{G} 89 \mathrm{PV} 90 \mathrm{~K}}$ Expression. Die Befunde sind überraschend, da die Wildtyp-FKBP12.6-Überexpression in 
Kardiomyozyten eine Steigerung der relativen Zellverkürzung bewirkt. Die negativ inotrope Wirkung der Mutante weist darauf hin, dass die FKBP-vermittelte Bindung von Calcineurin am RyR2 tatsächlich eine regulatorische Funktion innehat. Damit sind die bekannten Wirkungen einer FKBP-Bindung an den RyR wie die verminderte Offenwahrscheinlichkeit und die synchronisierte Öffnung benachbarter Kanäle sehr wahrscheinlich zum Teil Calcineurin-vermittelt. Um diese Annahme zu stützen und die Details der Calcineurinwirkung am RyR zu klären, sind jedoch weitere Untersuchungen notwendig. 


\section{LITERATURVERZEICHNIS}

Allen DG, Kentish JC (1988): Calcium concentration in the myoplasm of skinned ferret ventricular muscle following changes in muscle length. J Physiol 407, 489-503

Bandyopadhyay A, Shin DW, Ahn JO, Kim DH (2000): Calcineurin regulates ryanodine receptor/ $\mathrm{Ca}^{2+}$-release channels in rat heart. Biochem $\mathrm{J} \underline{352}, 61-70$

Barouch LA, Harrison RW, Skaf MW, Rosas GO, Cappola TP, Kobeissi ZA, Hobal IA, Lemmon CA, Burnett AL, O’Rourke B, Rodriguez ER, Huang PL, Lima JA, Berkowitz DE, Hare JM (2002): Nitric oxide regulates the heart by spatial confinement of nitric oxide synthase isoforms. Nature $\underline{416}, 337-339$

Bergelson JM, Cunningham JA, Droguett G, Kurt-Jones EA, Krithivas A, Hong JS, Horwitz MS, Crowell RL, Finberg RW (1997): Isolation of a common receptor for Coxsackie B viruses and adenoviruses 2 and 5. Science 275, 1320-1323

Berridge MJ (1993): Inositol trisphosphate and calcium signalling. Nature $\underline{361}$, 315-325

Bers DM (2000): Calcium fluxes involved in control of cardiac myocyte contraction. Circ Res $\underline{87}, 275-281$

Bers DM, Eisner DA, Valdivia HH (2003): Sarcoplasmic reticulum $\mathrm{Ca}^{2+}$ and heart failure: roles of diastolic leak and $\mathrm{Ca}^{2+}$ transport. Circ Res $\underline{93}$, 487-90

Bezprozvanny I, Watras J, Ehrlich BE (1991): Bell-shaped calcium-response curves of Ins(1,4,5)P3- and calcium-gated channels from endoplasmic reticulum of cerebellum. Nature $\underline{351}, 751-754$

Bowditch HP (1871): Über die Eigentümlichkeiten der Reizbarkeit, welche die Muskeln des Herzens zeigen. Ber Sachs Ges (Akad) Wiss 23, 652-689 
Bridge JH, Smolley JR, Spitzer KW (1990): The relationship between charge movements associated with ICa and INa-Ca in cardiac myocytes. Science $\underline{248}, 376-378$

Brillantes AB, Ondrias K, Scott A, Kobrinsky E, Ondriasová E, Moschella MC, Jayaraman T, Landers M, Ehrlich BE, Marks AR (1994): Stabilization of calcium release channel (ryanodine receptor) function by FK506-binding protein. Cell 77, 513-523

Bristow MR, Ginsburg R, Minobe W, Cubicciotti RS, Sageman WS, Lurie K, Billingham ME, Harrison DC, Stinson EB (1982): Decreased catecholamine sensitivity and betaadrenergic-receptor density in failing human hearts. N Engl J Med $\underline{307}$, 205-211

Bristow MR, Ginsburg R, Umans V, Fowler M, Minobe W, Rasmussen R, Zera P, Menlove R, Shah P, Jamieson S et al. (1986): Beta 1- and beta 2-adrenergic-receptor subpopulations in nonfailing and failing human ventricular myocardium: coupling of both receptor subtypes to muscle contraction and selective beta 1-receptor down-regulation in heart failure. Circ Res $\underline{59}$, 297-309

Brodde OE (1991): Beta 1- and beta 2-adrenoceptors in the human heart: properties, function, and alterations in chronic heart failure. Pharmacol Rev $\underline{43}$, 203-242

Cameron AM, Steiner JP, Roskams AJ, Ali SM, Ronnett GV, Snyder SH (1995): Calcineurin associated with the inositol 1,4,5-trisphosphate receptor-FKBP12 complex modulates $\mathrm{Ca}^{2+}$ flux. Cell $\underline{83}, 463-472$

Cameron AM, Nucifora FC Jr, Fung ET, Livingston DJ, Aldape RA, Ross CA, Snyder SH (1997): FKBP12 binds the inositol 1,4,5-trisphosphate receptor at leucine-proline (14001401) and anchors calcineurin to this FK506-like domain. J Biol Chem 272, 27582-27588

Cannell MB, Cheng H, Lederer WJ (1995): The control of calcium release in heart muscle. Science 268, 1045-1049

Clipstone NA, Crabtree GR (1992): Identification of calcineurin as a key signalling enzyme in T-lymphocyte activation. Nature $\underline{357}, 695-697$ 
Collins JH (1991): Sequence analysis of the ryanodine receptor: possible association with a 12K, FK506-binding immunophilin/protein kinase C inhibitor. Biochem Biophys Res Commun $\underline{178}, 1288-1290$

Crabtree GR (1999): Generic signals and specific outcomes: signaling through $\mathrm{Ca}^{2+}$, calcineurin, and NF-AT. Cell 96, 611-614

Dipla K, Mattiello JA, Margulies KB, Jeevanandam V, Houser SR (1999): The sarcoplasmic reticulum and the $\mathrm{Na}^{+} / \mathrm{Ca}^{2+}$ exchanger both contribute to the $\mathrm{Ca}^{2+}$ transient of failing human ventricular myocytes. Circ Res $\underline{84}$, 435-444

Doi M, Yano M, Kobayashi S, Kohno M, Tokuhisa T, Okuda S, Suetsugu M, Hisamatsu Y, Ohkusa T, Kohno M, Matsuzaki M (2002): Propranolol prevents the development of heart failure by restoring FKBP12.6-mediated stabilization of ryanodine receptor. Circulation $\underline{105}$, 1374-1379

Dolmetsch RE, Lewis RS, Goodnow CC, Healy JI (1997): Differential activation of transcription factors induced by $\mathrm{Ca}^{2+}$ response amplitude and duration. Nature $\underline{386}, 855-858$

Engelhardt S, Hein L, Wiesmann F, Lohse MJ (1999): Progressive hypertrophy and heart failure in $\beta_{1}$-adrenergic receptor transgenic mice. Proc Natl Acad Sci USA $\underline{96}$, 7059-7064

Fabiato A (1983): Calcium-induced release of calcium from the cardiac sarcoplasmic reticulum. Am J Physiol 245, C1-14

Fabiato A und Fabiato F (1979): Calcium and cardiac excitation-contraction coupling. Annu. Rev. Physiol. $\underline{41}, 473$ - 484

Farrell EF, Antaramian A, Rueda A, Gómez AM, Valdivia HH (2003): Sorcin inhibits calcium release and modulates excitation-contraction coupling in the heart. J Biol Chem $\underline{278}$, 34660-34666

Ferris CD, Snyder SH (1992): Inositol 1,4,5-trisphosphate-activated calcium channels. Annu Rev Physiol 54, 469-488 
Feuerstein GZ, Young PR (2000): Apoptosis in cardiac diseases: stress- and mitogenactivated signaling pathways. Cardiovasc Res $\underline{45}, 560-569$

Fischer G, Bang H, Berger E, Schellenberger A (1984 a): Conformational specificity of chymotrypsin toward proline-containing substrates. Biochim Biophys Acta $\underline{791}$, 87-97

Fischer G, Bang H, Mech C (1984 b): Nachweis einer Enzymkatalyse für die cis-transIsomerisierung der Peptidbindung in prolinhaltigen Peptiden. Biomed Biochim Acta $\underline{43}$, $1101-1111$

Fischer G, Wittmann-Liebold B, Lang K, Kiefhaber T, Schmid FX (1989): Cyclophilin and peptidyl-prolyl cis-trans isomerase are probably identical proteins. Nature $\underline{337}, 476-478$

Frank O (1895): Zur Dynamik des Herzmuskels. Z Biol 32, 370-437

Franzini-Armstrong C (1970): Studies of the triad. I. Structure of the junction in frog twitch fibers. J Cell Biol 47, 488-499

Franzini-Armstrong C, Protasi F, Ramesh V (1999): Shape, size, and distribution of $\mathrm{Ca}^{2+}$ release units and couplons in skeletal and cardiac muscle. Biophys $\mathbf{J} \underline{77}, 1528-1539$

Gordon AM, Huxley AF, Julian FJ (1966): The variation in isometric tension with sarcomere length in vertebrate muscle fibres. J Physiol 184, 170-192

Gorza L, Schiaffino S, Volpe P (1993): Inositol 1,4,5-trisphosphate receptor in heart: evidence for its concentration in purkinje myocytes of the conduction system. J Cell Biol 121 , $345-353$

Graham FL, Smiley J, Russell WC, Nairn R (1977): Characteristics of a human cell line transformed by DNA from human adenovirus type 5. J Gen Virol $\underline{36}, 59-74$

Groh S, Marty I, Ottolia M, Prestipino G, Chapel A, Villaz M, Ronjat M (1999): Functional interaction of the cytoplasmic domain of triadin with the skeletal ryanodine receptor. J Biol Chem 274, 12278-12283 
Gulati J (1992): Length-sensing function of troponin C and Starling's law of the heart. Circulation $\underline{85}, 1954-1955$

Hammes A, Oberdorf-Maass S, Rother T, Nething K, Gollnick F, Linz KW, Meyer R, Hu K, Han H, Gaudron P, Ertl G, Hoffmann S, Ganten U, Vetter R, Schuh K, Benkwitz C, Zimmer HG, Neyses L (1998): Overexpression of the sarcolemmal calcium pump in the myocardium of transgenic rats. Circ Res $\underline{83}, 877-888$

Harding MW, Galat A, Uehling DE, Schreiber SL (1989): A receptor for the immunosuppressant FK506 is a cis-trans peptidyl-prolyl isomerase. Nature $\underline{341}$, 758-60

Hasenfuss G, Seidler T (2003): Treatment of heart failure through stabilisation of the cardiac ryanodine receptor. Circulation $\underline{107}, 378-380$

Hasenfuss G, Reinecke H, Studer R, Meyer M, Pieske B, Holtz J, Holubarsch C, Posival H, Just H, Drexler H (1994): Relation between myocardial function and expression of sarcoplasmatic reticulum $\mathrm{Ca}^{2+}$-ATPase in failing and nonfailing human myocardium. Circ Res $\underline{75}, 434-442$

Hasenfuss G, Meyer M, Schillinger W, Preuss M, Pieske B, Just H (1997): Calcium handling proteins in the failing human heart. Basic Res Cardiol 92, 87-93

Holubarsch C, Ruf T, Goldstein DJ, Ashton RC, Nickl W, Pieske B, Pioch K, Ludemann J, Wiesner S, Hasenfuss G, Posival H, Just H, Burkhoff D (1996): Existence of the FrankStarling mechanism in the failing human heart. Investigations on the organ, tissue, and sarcomere levels. Circulation 94, 683-689

Huxley H, Hanson J (1954): Changes in the cross-striations of muscle during contraction and stretch and their structural interpretation. Nature 173, 973-976

Iino M, Tsukioka M (1994): Feedback control of inositol trisphosphate signalling by calcium. Mol Cell Endocrinol 98, 141-146 
Ito H, Hirata Y, Hiroe M, Tsujino M, Adachi S, Takamoto T, Nitta M, Taniguchi K, Marumo F (1991): Endothelin-1 induces hypertrophy with enhanced expression of muscle-specific genes in cultured neonatal rat cardiomyocytes. Circ Res $\underline{69}$, 209-215

James P, Inui M, Tada M, Chiesi M, Carafoli E (1989): Nature and site of phospholamban regulation of the $\mathrm{Ca}^{2+}$ pump of sarcoplasmic reticulum. Nature $\underline{342,90-92}$

Jayaraman T, Brillantes AM, Timerman AP, Fleischer S, Erdjument-Bromage H, Tempst P, Marks AR (1992): FK506 binding protein associated with the calcium release channel (ryanodine receptor). J Biol Chem $\underline{267}, 9474-9477$

Jeyakumar LH, Ballester L, Cheng DS, McIntyre JO, Chang P, Olivey HE, Rollins-Smith L, Barnett JV, Murray K, Xin HB, Fleischer S (2001): FKBP binding characteristics of cardiac microsomes from diverse vertebrates. Biochem Biophys Res Commun 281, 979-986

Kaftan E, Marks AR, Ehrlich BE (1996): Effects of rapamycin on ryanodine receptor/Ca ${ }^{2+}$ release channels from cardiac muscle. Circ Res $\underline{78}$, 990-997

Kohomoto O, Levi AJ, Bridge JH (1994): Relation between reverse sodium-calcium exchange and sarcoplasmic reticulum calcium release in guinea pig ventricular cells. Circ Res $\underline{74}, 550-554$

Laemmli UK (1970): Cleavage of structural proteins during the assembly of the head of bacteriophage T4. Nature $227,680-685$

Langendorff O (1895): Untersuchungen am überlebenden Säugetierherzen. Pflügers Arch Ges Physiol 61, 291-297

Lehnart SE, Janssen PM, Franz WM, Donahue JK, Lawrence JH, Marbán E, Prestle J, Hasenfuss G (2000): Preservation of myocardial function after adenoviral gene transfer in isolated myocardium. Am J Physiol Heart Circ Physiol 279, H986-991

Lehnart SE, Huang F, Marx SO, Marks AR (2003): Immunophilins and coupled gating of ryanodine receptors. Curr Top Med Chem $\underline{3}$, 1383-1391 
Lehnart SE, Terrenoire C, Reiken S, Wehrens XH, Song LS, Tillman EJ, Mancarella S, Coromilas J, Lederer WJ, Kass RS, Marks AR (2006): Stabilization of cardiac ryanodine receptor prevents intracellular calcium leak and arrhythmias. Proc Natl Acad Sci USA $\underline{103}$, 7906-7910

Lim HW, De Windt LJ, Steinberg L, Taigen T, Witt SA, Kimball TR, Molkentin JD (2000): Calcineurin expression, activation, and function in cardiac pressure-overload hypertrophy. Circulation 101, 2431-2437

Liu J, Farmer JD Jr, Lane WS, Friedman J, Weissman I, Schreiber SL (1991): Calcineurin is a common target of cyclophilin-cyclosporin A and FKBP-FK506 complexes. Cell $\underline{66}, 807-815$

Loughrey CM, Seidler T, Miller SL, Prestle J, MacEachern KE, Reynolds DF, Hasenfuss G, Smith GL (2004): Over-expression of FK506-binding protein FKBP12.6 alters excitationcontraction coupling in adult rabbit cardiomyocytes. J Physiol 556, 919-934

MacLennan DH, Rice WJ, Green NM (1997): The mechanism of $\mathrm{Ca}^{2+}$ transport by sarco(endo)plasmic reticulum $\mathrm{Ca}^{2+}$-ATPases. J Biol Chem $\underline{272}$, 28815-28818

Maier LS, Bers DM (2002): Calcium, calmodulin, and calcium-calmodulin kinase II: heartbeat to heartbeat and beyond. J Mol Cell Cardiol 34, 919-939

Marks AR (1997): Intracellular calcium-release channels: regulators of cell life and death. Am J Physiol 272, H597-605

Marks AR (2000): Cardiac intracellular calcium release channels: role in heart failure. Circ Res $\underline{87}, 8-11$

Marks AR (2001): Ryanodine receptors/calcium release channels in heart failure and sudden cardiac death. J Mol Cell Cardiol 33, 615-24

Marks AR, Tempst P, Hwang KS, Taubman MB, Inui M, Chadwick C, Fleischer S, NadalGinard B (1989): Molecular cloning and characterization of the ryanodine receptor/junctional channel complex cDNA from skeletal muscle sarcoplasmic reticulum. Proc Natl Acad Sci USA $\underline{86}, 8683-8687$ 
Marks AR, Fleischer S, Tempst P (1990): Surface topography analysis of the ryanodine receptor/junctional channel complex based on proteolysis sensitivity mapping. J Biol Chem $\underline{265}, 13143-13149$

Marx SO, Reiken S, Hisamatsu Y, Jayaraman T, Burkhoff D, Rosemblit N, Marks AR (2000): PKA phosphorylation dissociates FKBP12.6 from the calcium release channnel (ryanodine receptor): defective regulation in failing hearts. Cell $\underline{101}, 365-376$

Marx SO, Gaburjakova J, Gaburjakova M, Henrikson C, Ondrias K, Marks AR (2001): Coupled gating between cardiac calcium release channels (ryanodine receptors). Circ Res $\underline{88}$, $1151-1158$

Mella M, Colotti G, Zamparelli C, Verzili D, Ilari A, Chiancone E (2003): Information transfer in the penta-EF-hand protein Sorcin does not operate via the canonical structural/functional pairing. A study with site-specific mutants. J Biol Chem 278, 2492124928

Meyers MB, Pickel VM, Sheu SS, Sharma VK, Scotto KW, Fishman GI (1995): Association of sorcin with the cardiac ryanodine receptor. J Biol Chem $\underline{270}$, 26411-26418

Meyers MB, Fischer A, Sun YJ, Lopes CM, Rohacs T, Nakamura TY, Zhou YY, Lee PC, Altschuld RA, McCune SA, Coetzee WA, Fishman GI (2003): Sorcin regulates excitationcontraction coupling in the heart. J Biol Chem 278, 28865-28871

Mitchell RD, Simmerman HK, Jones LR (1988): $\mathrm{Ca}^{2+}$ binding effects on protein conformation and protein interactions of canine cardiac calsequestrin. J Biol Chem 263, 13761381

Molkentin JD, Lu JR, Antos CL, Markham B, Richardson J, Robbins J, Grant SR, Olson EN (1998): A calcineurin-dependent transcriptional pathway for cardiac hypertrophy. Cell $\underline{93}$, $215-228$

Moschella MC, Marks AR (1993): Inositol 1,4,5-trisphosphate receptor expression in cardiac myocytes. J Cell Biol 120, 1137-1146 
Mulieri LA, Hasenfuss G, Leavitt B, Allen PD, Alpert NR (1992): Altered myocardial forcefrequency relation in human heart failure. Circulation $\underline{85}, 1743-1750$

Näbauer M, Callewaert G, Cleeman L, Morad M (1989): Regulation of calcium release is gated by calcium current, not gating charge, in cardiac myocytes. Science $244,800-803$

Olson EN, Molkentin JD (1999): Prevention of cardiac hypertrophy by calcineurin inhibition: hope or hype? Circ Res $\underline{84}, 623-632$

Olson EN, Williams RS (2000): Calcineurin signaling and muscle remodelling. Cell 101, 689692

Passier R, Zeng H, Frey N, Naya FJ, Nicol RL, McKinsey TA, Overbeek P, Richardson JA, Grant SR, Olson EN (2000): CaM kinase signaling induces cardiac hypertrophy and activates the MEF2 transcription factor in vivo. J Clin Invest 105, 1395-1406

Piacentino V 3rd, Weber CR, Chen X, Weisser-Thomas J, Margulies KB, Bers DM, Houser SR (2003): Cellular basis of abnormal calcium transients of failing human ventricular myocytes. Circ Res $\underline{92}, 651-658$

Pieske B, Beyermann B, Breu V, Löffler BM, Schlotthauer K, Maier LS, Schmidt-Schweda S, Just H, Hasenfuss G (1999): Functional effects of endothelin and regulation of endothelin receptors in isolated human nonfailing and failing myocardium. Circulation 99, 1802-1809

Piot C, Lemaire S, Albat B, Seguin J, Nargeot J, Richard S (1996): High frequency-induced upregulation of human cardiac calcium currents. Circulation 93, 120-128

Pogwizd SM, Qi M, Yuan W, Samarel AM, Bers DM (1999): Upregulation of $\mathrm{Na}^{+} / \mathrm{Ca}^{2+}$ exchanger expression and function in an arrhythmogenic rabbit model of heart failure. Circ Res 85, 1009-1019

Prestle J, Janssen PM, Janssen AP, Zeitz O, Lehnart SE, Bruce L, Smith GL, Hasenfuss G (2001): Overexpression of FK506-binding protein FKBP12.6 in cardiomyocytes reduces 
ryanodine receptor-mediated $\mathrm{Ca}(2+)$ leak from the sarcoplasmic reticulum and increases contractility. Circ Res $\underline{88}, 188-194$

Reiken S, Gaburjakova M, Gaburjakova J, He Kl KL, Prieto A, Becker E, Yi Gh GH, Wang J, Burkhoff D, Marks AR (2001): beta-adrenergic receptor blockers restore cardiac calcium release channel (ryanodine receptor) structure and function in heart failure. Circulation 104, $2843-2848$

Rochais F, Vilardaga JP, Nikolaev VO, Bünemann M, Lohse MJ, Engelhardt S (2007): Realtime optical recording of beta1-adrenergic receptor activation reveals supersensitivity of the Arg389 variant to carvedilol. J Clin Invest 117, 229-235

Ruehr ML, Russell MA, Ferguson DG, Bhat M, Ma J, Damron DS, Scott JD, Bond M (2003): Targeting of protein kinase A by muscle A kinase-anchoring protein (mAKAP) regulates phosphorylation and function of the skeletal muscle ryanodine receptor. J Biol Chem $\underline{278}$, 24831-24836

Rust EM, Westfall MV, Metzger JM (1998): Stability of the contractile assembly and $\mathrm{Ca}^{2+}{ }_{-}$ activated tension in adenovirus infected adult cardiac myocytes. Mol Cell Biochem $\underline{181}, 143-$ 155

Sabatini DM, Erdjument-Bromage H, Lui M, Tempst P, Snyder SH (1994): RAFT1: a mammalian protein that binds to FKBP12 in a rapamycin-dependent fashion and is homologous to yeast TORs. Cell $\underline{78}, 35-43$

Saiki RK, Scharf S, Faloona F, Mullis KB, Horn GT, Erlich HA, Arnheim N (1985): Enzymatic amplification of beta-globin genomic sequences and restriction site analyses for diagnosis of sickle cell anemia. Science. $\underline{230}, 1350-1354$

Schwinger RH, Böhm M, Koch A, Schmidt U, Morano I, Eissner HJ, Uberfuhr R, Reichart B, Erdmann E (1994): The failing human heart is unable to use the Frank-Starling mechanism. Circ Res $\underline{74}, 959-969$ 
Seidler T, Miller SL, Loughrey CM, Kania A, Burow A, Kettlewell S, Teucher N, Wagner S, Kögler H, Meyers MB, Hasenfuss G, Smith GL (2003): Effects of adenovirus-mediated sorcin overexpression on excitation-contraction coupling in isolated rabbit cardiomyocytes. Circ Res 93, 132-139

Seidler T, Loughrey CM, Zibrova D, Kettlewell S, Teucher N, Kögler H, Hasenfuss G, Smith GL (2007): Overexpression of FK-506-binding protein 12.0 modulates excitation-contraction coupling in adult rabbit ventricular cardiomyocytes. Circ Res $\underline{101}, 1020-10029$

Sewell TJ, Lam E, Martin MM, Leszyk J, Weidner J, Calaycay J, Griffin P, Williams H, Hung S, Cryan J (1994): Inhibition of calcineurin by a novel FK-506-binding protein. J Biol Chem 269, 21094-21102

Shigekawa M, Iwamoto $\mathrm{T}$ (2001): Cardiac $\mathrm{Na}^{+}-\mathrm{Ca}^{2+}$ exchange: molecular and pharmacological aspects. Circ Res $\underline{88}, 864-876$

Shou W, Aghdasi B, Armstrong DL, Guo Q, Bao S, Charng MJ, Mathews LM, Schneider MD, Hamilton SL, Matzuk MM (1998): Cardiac defects and altered ryanodine receptor function in mice lacking FKBP12. Nature $\underline{391}$, 489-492

Siekierka JJ, Hung SH, Poe M, Lin CS, Sigal NH (1989): A cytosolic binding protein for the immunosuppressant FK506 has peptidyl-prolyl isomerase activity but is distinct from cyclophilin. Nature $\underline{341}, 755-757$

Sitsapesan R, Montgomery RA, Williams AJ (1995): New insights into the gating mechanisms of cardiac ryanodine receptors revealed by rapid changes in ligand concentration. Circ Res $\underline{77}, 765-772$

Solaro RJ, Rarick HM (1998): Troponin and tropomyosin: proteins that switch on and tune in the activity of cardiac myofilaments. Circ Res $\underline{83}, 471-480$

Studer R, Reinecke H, Bilger J, Eschenhagen T, Böhm M, Hasenfuss G, Just H, Holtz J, Drexler H (1994): Gene expression of the cardiac $\mathrm{Na}^{+}-\mathrm{Ca}^{2+}$ exchanger in end-stage human heart failure. Circ Res $\underline{75}$, 443-453 
Sun XH, Protasi F, Takahashi M, Takeshima H, Ferguson DG, Franzini-Armstrong C (1995): Molecular architecture of membranes involved in excitation-contraction coupling of cardiac muscle. J Cell Biol $\underline{129}$, 659-671

Sussman MA, Lim HW, Gude N, Taigen T, Olson EN, Robbins J, Colbert MC, Gualberto A, Wieczorek DF, Molkentin JD (1998): Prevention of cardiac hypertrophy in mice by calcineurin inhibition. Science $\underline{281}, 1690-1693$

Teucher N, Prestle J, Seidler T, Currie S, Elliot EB, Reynolds DF, Schott P, Wagner S, Kogler H, Inesi G, Bers DM, Hasenfuss G, Smith GL (2004): Excessive sarcoplasmic/endoplasmic reticulum $\mathrm{Ca}^{2+}$-ATPase expression causes increased sarcoplasmic reticulum $\mathrm{Ca}^{2+}$ uptake but decreases myocyte shortening. Circulation $\underline{110}$, 3553-3559

Timerman AP, Jayaraman T, Wiederrecht G, Onoue H, Marks AR, Fleischer S (1994): The ryanodine receptor from canine heart sarcoplasmic reticulum is associated with a novel FK506 binding protein. Biochem Biophys Res Commun 198, 701-706

Timerman AP, Wiederrecht G, Marcy A, Fleischer S (1995): Characterization of an exchange reaction between soluble FKBP-12 and the FKBP.ryanodine receptor complex. Modulation by FKBP mutants deficient in peptidyl-prolyl isomerase activity. J Biol Chem 270, 2451-2459

Timerman AP, Onoue H, Xin HB, Barg S, Copello J, Wiederrecht G, Fleischer S (1996): Selective binding of FKBP12.6 by the cardiac ryanodine receptor. J Biol Chem 271, 2038520391

Towbin H, Staehelin T, Gordon J (1979): Electrophoretic transfer of proteins from polyacrylamide gels to nitrocellulose sheets: procedure and some applications. Proc Natl Acad Sci U S A $\underline{76}, 4350-4354$

Valdivia HH, Kaplan JH, Ellis-Davies GC, Lederer WJ (1995): Rapid adaptation of cardiac ryanodine receptors: modulation by $\mathrm{Mg}^{2+}$ and phosphorylation. Science $267,1997-2000$

Weber CR, Piacentino V 3rd, Houser SR, Bers DM (2003): Dynamic regulation of Sodium/Calcium exchange function in human heart failure. Circulation $\underline{108}$, 2224-2229 
Wehrens XH, Lehnart SE, Huang F, Vest JA, Reiken SR, Mohler PJ, Sun J, Guatimosim S, Song LS, Rosemblit N, D'Armiento JM, Napolitano C, Memmi M, Priori SG, Lederer WJ, Marks AR (2003): FKBP12.6 deficiency and defective calcium release channel (ryanodine receptor) function linked to exercise-induced sudden cardiac death. Cell $\underline{113}, 829-40$

Wehrens XH, Lehnart SE, Reiken SR, Marks AR (2004): $\mathrm{Ca}^{2+} / \mathrm{Calmodulin}$-dependent protein kinase II phosphorylation regulates the cardiac ryanodine receptor. Circ Res $\underline{94}$, e61-70

Wehrens XH, Lehnart SE, Reiken S, van der Nagel R, Morales R, Sun J, Cheng Z, Deng SX, de Windt LJ, Landry DW, Marks AR (2005): Enhancing calstabin binding to ryanodine receptors improves cardiac and skeletal muscle function in heart failure. Proc Natl Acad Sci USA $\underline{102}, 9607-9612$

Wickham TJ, Mathias P, Cheresh DA, Nemerow GR (1993): Integrins alpha v beta 3 and alpha $\mathrm{v}$ beta 5 promote adenovirus internalization but not virus attachment. Cell $\underline{73}, 309-319$

Xin HB, Rogers K, Qi Y, Kanematsu T, Fleischer S (1999): Three amino acid residues determine selective binding of FK506-binding protein 12.6 to the cardiac ryanodine receptor. J Biol Chem 274, 15315-15319

$\mathrm{Xu}$ L, Meissner G (1998): Regulation of cardiac muscle $\mathrm{Ca}^{2+}$ release channel by sarcoplasmic reticulum lumenal $\mathrm{Ca}^{2+}$. Biophys $\mathrm{J} \underline{75}, 2302-2312$

Xu L, Eu JP, Meissner G, Stamler JS (1998): Activation of the cardiac calcium release channel (ryanodine receptor) by poly-S-nitrosylation. Science $\underline{279}, 234-237$

Yamazaki T, Komuro I, Kudoh S, Zou Y, Shiojima I, Mizuno T, Takano H, Hiroi Y, Ueki K, Tobe K, Kadowaki T, Nagai R, Yazaki Y (1995): Angiotensin II partly mediates mechanical stress-induced cardiac hypertrophy. Circ Res $\underline{77,}$, 258-265

Yanagisawa M, Kurihara H, Kimura S, Tomobe Y, Kobayashi M, Mitsui Y, Yazaki Y, Goto K, Masaki T (1988): A novel potent vasoconstrictor peptide produced by vascular endothelial cells. Nature $\underline{332}, 411-415$ 
Yang D, Rosen MK, Schreiber SL (1993): A composite FKBP12-FK506 surface that contacts calcineurin. J Am Chem Soc $\underline{115}, 819-820$

Yano M, Ono K, Ohkusa T, Suetsugu M, Kohno M, Hisaoka T, Kobayashi S, Hisamatsu Y, Yamamoto T, Kohno M, Noguchi N, Takasawa S, Okamoto H, Matsuzaki M (2000): Altered stoichiometry of FKBP12.6 versus ryanodine receptor as a cause of abnormal $\mathrm{Ca}^{2+}$ leak through ryanodine receptor in heart failure. Circulation 102, 2131-2136

Yokoyama T, Nakano M, Bednarczyk JL, McIntyre BW, Entman M, Mann DL (1997): Tumor necrosis factor- $\alpha$ provokes a hypertrophic growth response in adult cardiac myocytes. Circulation 95, 1247-1252

Zhang L, Kelley J, Schmeisser G, Kobayashi YM, Jones LR (1997): Complex formation between junctin, triadin, calsequestrin, and the ryanodine receptor. Proteins of the cardiac junctional sarcoplasmic reticulum membrane. J Biol Chem 272, 23389-23397

Zhang W, Kowal RC, Rusnak F, Sikkink RA, Olson EN, Victor RG (1999): Failure of calcineurin inhibitors to prevent pressure-overload left ventricular hypertrophy in rats. Circ Res $\underline{84}, 722-728$ 


\section{Danksagung}

Mein Dank gilt an erster Stelle Prof. Dr. med. Gerd Hasenfuß für die Überlassung des Dissertationsthemas und die zahlreichen Hilfestellungen, die zur Entstehung dieser Arbeit in erheblichen Maße beigetragen haben. Seine Begeisterung für Medizin, Wissenschaft und die Verknüpfung beider vermag er nicht nur im Hörsaal an die Studenten zu vermitteln. Durch sein Engagement weckte er auch im täglichen Laboralltag die Freude an der Forschung bei allen wissenschaftlichen Mitarbeitern. Sein zielgerichteter Ratschlag half an vielen Punkten, den richtigen Weg zu finden bzw. eine falsche Fährte zu erkennen.

Auch wenn ich in meiner weiteren medizinischen Laufbahn keinen direkten Kontakt zu ihm haben werde, wird mir sein Beispiel immer als Leitbild dienen.

Mein besonderer Dank gilt Dr. med. Tim Seidler, ein leidenschaftlicher Wissenschaftler und ausgezeichneter Mediziner. Er hat mir durch Vermittlung molekulargenetischer Grundlagenmethoden die Forschung näher gebracht und mich gelehrt, wissenschaftlich fundiert $\mathrm{zu}$ arbeiten. Er hat mir aber auch gezeigt, dass Fehlschläge und Misserfolge Bestandteil der wissenschaftlichen Arbeit sind und diese wiederum den Weg in die richtige Richtung weisen. Durch seine Fähigkeit, ein Problem niemals aufzugeben, bevor es nicht gelöst ist, hat er diese Arbeit erst ermöglicht.

Auch sein Bild eines Mediziners, der seinen Beruf als Berufung sieht, wird mich in meinem weiteren Leben als Vorbild begleiten.

Ein Dank auch an Dr. rer. nat. Jürgen Prestle, der mich in die Grundlagen der wissenschaftlichen Arbeit eingeführt hat. Auch wenn ich nur kurz unter seiner Leitung gearbeitet habe, so bleibt er mir als hervorragender, aber gleichzeitig sehr besonnener Wissenschaftler in Erinnerung.

Ein spezieller Dank gilt den technischen Assistenten des Labors, Frau Sandra Ott-Gebauer, Frau Jessica Spitalieri und Herr Michael Kothe, die durch ihr zuverlässiges und fleißiges Wirken immer die gute Seele des Labors für mich waren. Auch sie tragen einen Anteil am Gelingen dieser Arbeit. 
Des Weiteren danke ich Dr. med. Nils Teucher, Michael Kothe und Dr. med. Stefan Wagner, die die Isolation von Kardiomyozyten aus Kaninchenherzen im Labor durchführten.

Auch wenn ich in meiner weiteren medizinischen Laufbahn keinen direkten Kontakt zur Forschung haben werde, so schöpfe ich doch weiter aus den vielen Fähigkeiten und Erkenntnissen, die mir die wissenschaftliche Arbeit im Labor vermittelt hat.

Deshalb möchte ich nochmals allen, Genannten und Ungenannten, für ihr Mitwirken am Gelingen dieses Projektes danken. 